\title{
Powering MEMS portable devices- a review of non-regenerative and regenerative power supply systems with special emphasis on piezoelectric energy harvesting systems
}

\author{
K A Cook-Chennault ${ }^{1}$, N Thambi ${ }^{2}$ and A M Sastry ${ }^{3,4,5}$ \\ ${ }^{1}$ Mechanical Engineering and Mechanics Department, Drexel University, Philadelphia, \\ PA 19104, USA \\ ${ }^{2}$ Department of Biomedical Engineering, Drexel University, Philadelphia, PA 19104, USA \\ ${ }^{3}$ Department of Mechanical Engineering, University of Michigan, Ann Arbor, \\ MI 48105, USA \\ ${ }^{4}$ Department of Materials Science Engineering, University of Michigan, Ann Arbor, \\ MI 48105, USA \\ ${ }^{5}$ Department of Biomedical Engineering, University of Michigan, Ann Arbor, MI 48105, USA
}

Received 3 August 2007, in final form 24 March 2008

Published 9 June 2008

Online at stacks.iop.org/SMS/17/043001

\begin{abstract}
Power consumption is forecast by the International Technology Roadmap of Semiconductors (ITRS) to pose long-term technical challenges for the semiconductor industry. The purpose of this paper is threefold: (1) to provide an overview of strategies for powering MEMS via non-regenerative and regenerative power supplies; (2) to review the fundamentals of piezoelectric energy harvesting, along with recent advancements, and (3) to discuss future trends and applications for piezoelectric energy harvesting technology. The paper concludes with a discussion of research needs that are critical for the enhancement of piezoelectric energy harvesting devices.
\end{abstract}

(Some figures in this article are in colour only in the electronic version)

\section{Nomenclature}

A Excitation acceleration

$A_{\mathrm{E}} \quad$ Area of the of electrostatic plates

$B \quad$ Flux density

$b_{\mathrm{m}} \quad$ Mechanical damping

C Capacitance

$C_{\mathrm{b}} \quad$ Capacitance of the bender

$C_{k} \quad$ Equivalent capacitance, which represents the mechanical stiffness

$C_{\text {Load }}$ Load capacitance

$C_{\mathrm{p}} \quad$ Elastic constant for the piezoelectric material
$C_{\mathrm{sh}} \quad$ Elastic constant for the center shim of the bimorph

d Piezoelectric strain coefficients

$D \quad$ Electric displacement

$d_{\mathrm{E}} \quad$ Separation between electrostatic plates

E Electric field

$\tilde{E} \quad$ Maximum energy density

$E_{\mathrm{C}} \quad$ Energy stored

$E_{\mathrm{E}} \quad$ Energy stored in an electrostatic system

$E_{\mathrm{y}} \quad$ Young's modulus

$F \quad$ Applied force

$F_{\text {a }} \quad$ Antiresonance frequency

$F_{\mathrm{E}} \quad$ Perpendicular force between electrostatic plates 
$F_{\mathrm{r}} \quad$ Resonance frequency

$g \quad$ Voltage coefficient

$i \quad$ Current

$k \quad$ Piezoelectric material electromechanical coupling factor

$k_{\text {eff }} \quad$ Effective electromechanical coupling factor

$l \quad$ Side length of the coil (assumed to be a square)

$l_{\mathrm{b}} \quad$ The length of the piezoelectric element not covered by the seismic mass

$l_{\mathrm{c}} \quad$ Length of the electrode covering the piezoelectric material

$L_{\text {coil }} \quad$ Coil inductance

$L_{\mathrm{m}} \quad$ Equivalent inductance/inertia of the generator

$m \quad$ Seismic mass

$N \quad$ The number of turns in the generator coil

$n \quad$ Data point index

$n^{\prime} \quad$ Equivalent turns ratio of the transformer

$p \quad$ Instantaneous power, pyroelectric constant

$\mathcal{P} \quad$ Pyroelectric constant

$P \quad$ Electrical power generated from sinusoidal excitation vibration

$\tilde{P}_{\text {ave }} \quad$ Average power density

$P_{\text {in }} \quad$ Input power

$P_{\text {out }} \quad$ Output power

$q \quad$ Damping coefficient

$q_{\mathrm{e}} \quad$ Electrical energy extracted by the transduction mechanism

$Q_{\text {E }} \quad$ Charge on electrostatic plates

$Q_{\mathrm{M}} \quad$ Mechanical quality factor

$q_{\mathrm{p}} \quad$ Parasitic losses

$R \quad$ Resistance

$R_{\mathrm{b}} \quad$ Equivalent resistance equal to the mechanical damping

$R_{\text {coil }} \quad$ Coil resistance

$R_{\text {load }} \quad$ Load resistance

$S \quad$ Strain tensor

$s^{\mathrm{E}} \quad$ Elastic compliance matrix evaluated at a constant electric field

$T \quad$ Elastic compliance matrix evaluated at a constant electric field

$t \quad$ Time

$t_{\mathrm{c}} \quad$ Thickness of the piezoelectric material

$t_{\mathrm{sh}} \quad$ Thickness of the shim material

$U_{\text {in }} \quad$ Input energy from the excitation vibrations per cycle

$U_{\text {out }} \quad$ Energy delivered to an electrical load

$V_{\mathrm{E}} \quad$ Voltage on electrostatic plates

$w \quad$ Width of the beam

y External sinusoidal vibration

$Y \quad$ Amplitude of vibration

$z \quad$ Displacement of seismic mass

$\alpha \quad$ Coefficient of thermal expansion

$\chi \quad$ Spring constant

$\varepsilon \quad$ Permittivity of the material

$\varepsilon_{o} \quad$ Permittivity of free

space $=8.854 \times 10^{-12} \mathrm{~F} \mathrm{~m}^{-1}$

$\varepsilon^{\mathrm{T}} \quad$ Permittivity values that are evaluated at a constant stress $\eta \quad$ Device efficiency

$\lambda$ Transmission coefficient

$M \quad$ Total number of data points measured

$v$ Constant obtained from empirical data

$\theta \quad$ Temperature difference

$\rho \quad$ Density of the proof mass material

$\sigma \quad$ Stress from mechanical loading

$\omega$ Excitation frequency

$\omega_{\mathrm{n}} \quad$ Natural frequency

$\zeta_{\mathrm{e}} \quad$ Electrical damping ratio

$\zeta_{\mathrm{p}}$ Parasitic mechanical damping ratio

$\zeta_{\mathrm{t}} \quad$ Transducer damping ratio

\section{Introduction}

Power consumption is forecast by the International Technology Roadmap of Semiconductors (ITRS) to pose long-term technical challenges for the semiconductor industry [1]. Higher chip operating frequencies, higher interconnect capacitance and resistance, and increasing gate leakage from on-chip transistors all contribute to the increasing power requirements of microprocessor units (MPUs) [1]. Indeed, the performance, mass and volumes, and lifetimes of power supplies presently limit most applications of microelectromechanical systems (MEMS) technology.

Two complementary strategies are presently being pursued for portable electronics. The first of these, miniaturization of power supplies, has included studies of thin film and microbatteries [2-10], microcombustors [11-17], microheat engines [18, 19], microturbines [20, 21] and microfuel cells [22-26] for powering MEMS. The devices listed in this first category typically fall under the category of nonregenerative power supplies, e.g. systems that have a finite amount or require a continuous supply of active materials or fuel for power generation. The second of these general strategies, in situ regenerative power supplies, can be implemented for standalone or hybrid power systems. Regenerative power technologies include power from microphotovoltaic arrays [27-33], microthermophotovoltaic cells [12, 34-39], electromagnetic [40, 41] and inductively coupled plasmas [42-46], acoustic noise [47-49], thermoelectrics [50-52], electrostatic [47, 53, 54] and piezoelectric [55-58] devices.

In this review, we provide an overview of state-of-the-art strategies for powering MEMS, with detailed discussions of both non-regenerative (section 2) and regenerative (section 3 ) power supplies. Then, we focus our attention on the use of piezoelectrics in energy harvesting (section 4), and discuss both the fundamentals of the technology, along with areas of usage and anticipated application. We close with a discussion of future trends and applications, along with research needs in the area of energy harvesting (section 5).

\section{Non-regenerative power supply}

\subsection{Batteries}

Electrochemical cells, because of their modularity, portability and practicality, are the most commonly used power source 
Table 1. Examples of mobile phones and the types of batteries used to power them, along with the percentage of total mass used by the portable battery.

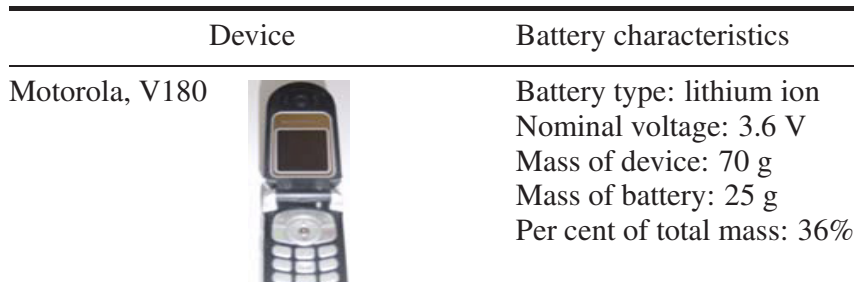

Blackberry

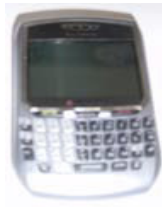

Dell Laptop

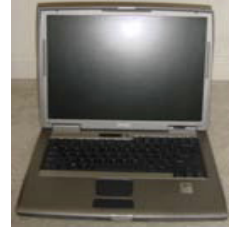

Battery type: lithium ion

Nominal voltage: $3.7 \mathrm{~V}$

Mass of device: $120 \mathrm{~g}$

Mass of battery: $20 \mathrm{~g}$

Per cent of total mass: $17 \%$

Battery type: lithium ion Nominal voltage: $11.1 \mathrm{~V}$

Mass of device: $2.435 \mathrm{~kg}$

Mass of battery: $315 \mathrm{~g}$

Per cent of total mass: $13 \%$

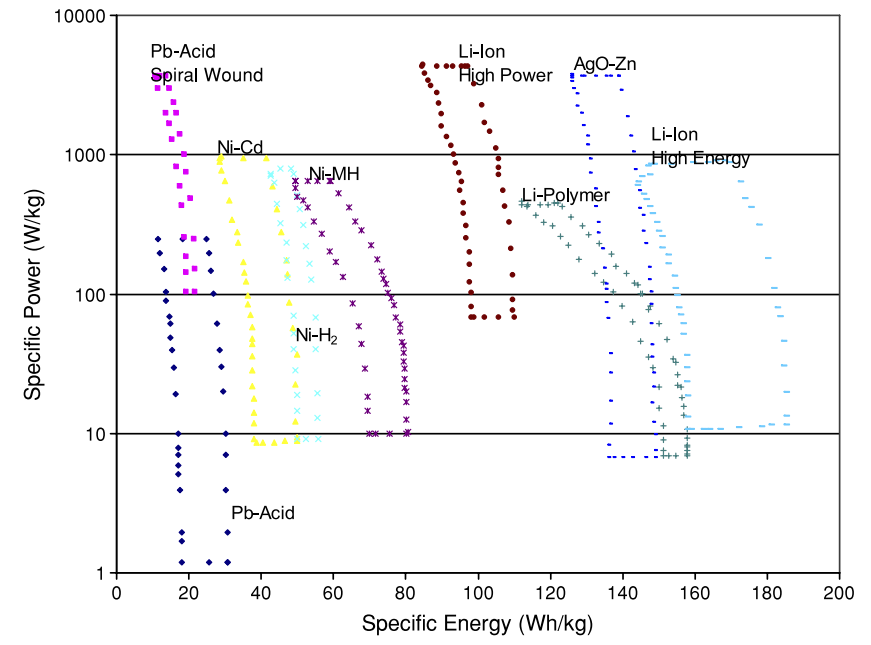

Figure 1. Ragone plot comparing the performance of various battery electrochemistries.

for complementary metal-oxide semiconductor (CMOS) based MEMS. Batteries can be used for both power generation and energy storage, provide continuous energy, have relatively high energy and power densities, and can generally be easily replaced without substantial modifications to a device. Batteries also provide direct and continuous current. They therefore do not require complex signal conditioning for conversion of alternating current to direct current, as do regenerative power supplies, such as photovoltaic, electromagnetic and piezoelectric generators. A Ragone plot comparing battery technologies is shown in figure 1 [59-67].

The majority of portable electronics are powered by prismatic, nickel metal hydride (NiMH), nickel cadmium or lithium-ion rechargeable batteries, wherein, the power system is several times larger than the size of the device itself [55]. The disparity between battery and host device size results from the nonlinear scaling of battery size with the diminishing sizes of transistors [1] in CMOS-based MEMS. For example, mobile phone batteries account for up to $36 \%$ of the mass of the entire phone, as shown in table 1 . The difficulty in reducing battery size is based on the inherent specific energy and energy densities of commonly used primary and secondary batteries (tables 2(a) and (b)) [2-7, 61, 68-73], and the inability of these batteries to meet growing life cycle demands of portable electronics and biomedical devices. Therefore a number of workers have developed lithium-ion thin-film, thick-film and 3D batteries (table 3) [2, 3, 9, 74-89] for powering MEMSbased portable electronics.

Lithium-ion cells are one of the most commonly used types of batteries for portable electronics. Lithium-ion thinfilm cells are comprised of metal oxides such as lithium cobalt $\left(\mathrm{LiCoO}_{2}\right)$, lithium manganese oxide $\left(\mathrm{LiMn}_{2} \mathrm{O}_{4}\right)$ and lithium nickel cobalt $\left(\mathrm{LiNi}_{1-x} \mathrm{Co}_{x} \mathrm{O}_{2}\right)$, for the positive electrode, a ceramic material for the negative electrode, a solid electrolyte and a current collector such as gold or platinum. These cells operate via a reversible intercalation process, wherein $\mathrm{Li}^{+}$ions are removed or inserted into a host material that is either metal oxide or graphite [73].

Lithium-ion cells are suitable for many portable electronics applications, but barriers remain to achieving sizes and form factors for more widespread adoption. Advantages of lithium-ion batteries are their relatively long cycle life, broad temperature range, long shelf life, low self-discharge rate, rapid charge capability, high rate and power discharge capability, high energy efficiency, high operating voltage, lack of memory effect, and high specific energy and energy density compared to other battery electrochemistries (table 2 [2-7, 61, 68-73] and table 3 [2, 3, 9, 74-89] and figure 1). 
Table 2. (a) Primary battery composition, nominal voltage, energy density, specific energy and shape. (b) Secondary battery composition, nominal voltage, energy density, specific energy and shape.

\begin{tabular}{|c|c|c|c|c|c|c|c|}
\hline & Anode & Cathode & Electrolyte & $\begin{array}{l}\text { Nominal } \\
\text { voltage } \\
\text { (V) }\end{array}$ & 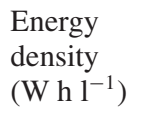 & $\begin{array}{l}\text { Specific } \\
\text { energy } \\
\left(\mathrm{Wh} \mathrm{kg}{ }^{-1}\right)\end{array}$ & Shapes \\
\hline Zinc/air & $\mathrm{Zn}$ & $\mathrm{O}_{2}$ & $\begin{array}{l}\mathrm{KOH} \\
\text { (aqueous } \\
\text { solution) }\end{array}$ & 1.5 & $1270-1560$ & $370-490$ & Button \\
\hline $\mathrm{Li} / \mathrm{SO}_{2}$ & $\mathrm{Li}$ & $\mathrm{SO}_{2}$ & $\begin{array}{l}\text { Organic solvent, } \\
\text { salt solution }\end{array}$ & $2.85-3.0$ & $313-498$ & $160-307$ & Cylindrical \\
\hline $\mathrm{Li} / \mathrm{SOCl}_{2}$ & $\mathrm{Li}$ & $\mathrm{SOCl}_{2}$ & $\begin{array}{l}\mathrm{SOCl}_{2} \\
\text { w/ } / \mathrm{AlCl}_{4}\end{array}$ & 3.6 & $715-1100$ & $380-537$ & $\begin{array}{l}\text { Cylindrical, spirally } \\
\text { wound, prismatic }\end{array}$ \\
\hline $\mathrm{Li} / \mathrm{MnO}_{2}$ & $\mathrm{Li}$ & $\mathrm{MnO}_{2}$ & $\begin{array}{l}\text { Organic solvent, } \\
\text { salt solution }\end{array}$ & 3.0 & $371-789$ & $129-343$ & $\begin{array}{l}\text { Button, cylindrical, } \\
\text { thin film and rectangular }\end{array}$ \\
\hline $\mathrm{Li} / \mathrm{FeS}_{2}$ & $\mathrm{Li}$ & $\mathrm{FeS}_{2}$ & $\begin{array}{l}\text { Organic solvent, } \\
\text { salt solution }\end{array}$ & 1.5 & $487-540$ & $247-310$ & Cylindrical \\
\hline $\mathrm{Li} / \mathrm{I}_{2}$ & $\mathrm{Li}$ & $\mathrm{I}_{2}(\mathrm{P} 2 \mathrm{VP})$ & Solid & 2.8 & $820-1030$ & $220-280$ & Button \\
\hline $\mathrm{Zn} / \mathrm{Ag}_{2} \mathrm{O}$ & $\mathrm{Zn}$ & $\mathrm{Ag}_{2} \mathrm{O}$ & $\begin{array}{l}\mathrm{KOH} \text { or } \mathrm{NaOH} \\
\text { (aqueous solution) }\end{array}$ & 1.5 & $207-543$ & $56-137$ & Button \\
\hline \multicolumn{8}{|c|}{ (b) } \\
\hline $\begin{array}{l}\text { Zinc/silver } \\
\text { oxide }\end{array}$ & $\mathrm{Zn}$ & $\mathrm{AgO}$ & $\begin{array}{l}\mathrm{KOH} \text { (aqueous } \\
\text { solution) }\end{array}$ & 1.5 & 180 & 105 & Prismatic \\
\hline $\begin{array}{l}\text { Nickel metal } \\
\text { hydride }\end{array}$ & $\mathrm{MH}$ & $\mathrm{NiOOH}$ & $\begin{array}{l}\mathrm{KOH} \text { (aqueous } \\
\text { solution) }\end{array}$ & 1.2 & $53-360$ & $41-100$ & $\begin{array}{l}\text { Cylindrical, button, } \\
\text { prismatic }\end{array}$ \\
\hline $\begin{array}{l}\text { Rechargeable } \\
\text { primary } \mathrm{Zn} / \mathrm{MnO}_{2}\end{array}$ & $\mathrm{Zn}$ & $\mathrm{MnO}_{2}$ & $\begin{array}{l}\mathrm{KOH} \text { (aqueous } \\
\text { solution) }\end{array}$ & 1.5 & $210-458$ & $51-150$ & cylindrical \\
\hline Lithium ion & $\mathrm{C}$ & $\mathrm{LiCoO}_{2}$ & $\begin{array}{l}\text { Organic } \\
\text { solvent }\end{array}$ & 4.0 & $200-450$ & $61-200$ & $\begin{array}{l}\text { Cylindrical and } \\
\text { prismatic }\end{array}$ \\
\hline $\begin{array}{l}\text { Lithium- } \\
\text { polymer }\end{array}$ & $\mathrm{C}$ & $\mathrm{LiFePO}_{4}$ & $\begin{array}{l}\text { Organic } \\
\text { solvent }\end{array}$ & 3.2 & $160-217$ & 74-91 & Prismatic \\
\hline
\end{tabular}

Table 3. Thin-film battery composition, current, voltage, dimensions and energy density.

\begin{tabular}{|c|c|c|c|c|c|c|}
\hline Description & Anode & Cathode & Electrolyte & $\begin{array}{l}\text { Current and } \\
\text { voltage }\end{array}$ & Dimensions & Energy density \\
\hline $\begin{array}{l}\text { Lithium-ion micro } \\
\text { 3D microchannel } \\
\text { plate (MCP) }\end{array}$ & $\begin{array}{l}\text { Lithiated } \\
\text { graphite }\end{array}$ & $\mathrm{MoS}_{2}$ & $\begin{array}{l}\text { Hybrid polymer } \\
\text { electrolyte (HPE) }\end{array}$ & $\begin{array}{l}\text { Cutoff voltage } \\
=1.3-2.2 \mathrm{~V}\end{array}$ & $\begin{array}{l}\text { MCP substrate } \\
\text { diameter }=13 \mathrm{~mm} \text {, } \\
\text { thickness }=0.5 \mathrm{~mm} \\
\text { Electrode active cell } \\
\text { area }=0.2 \mathrm{~cm}^{2}\end{array}$ & $\begin{array}{l}\text { Capacity }= \\
2.0 \mathrm{mAh} \mathrm{cm}^{-2}\end{array}$ \\
\hline \multirow[t]{2}{*}{$\begin{array}{l}\text { Thin-film lithium } \\
\text { ion }\end{array}$} & $\mathrm{LiCoO}_{2}$ & $\begin{array}{l}\text { Amorphous } \\
\mathrm{SnO}\end{array}$ & $\begin{array}{l}\text { Amorphous } \\
\text { LVSO solid } \\
\text { electrolyte }\end{array}$ & $2.7 \mathrm{~V}$ & $\begin{array}{l}\text { Area- }-0.23 \mathrm{~cm}^{2} \\
\text { Thickness }-2 \mu \mathrm{m}\end{array}$ & \\
\hline & & & & $\begin{array}{l}\text { Current density } \\
=200 \mu \mathrm{A} \mathrm{cm}^{-2}\end{array}$ & & 一 \\
\hline \multirow[t]{2}{*}{$\begin{array}{l}\text { Thin-film lithium } \\
\left(\mathrm{Li} / \mathrm{MoO}_{3}\right)\end{array}$} & $\mathrm{Li}$ & $\mathrm{MoO}_{3-x}$ & $\begin{array}{l}\mathrm{Li}_{2} \mathrm{O}-\mathrm{V}_{2} \mathrm{O}_{5}-\mathrm{SiO}_{2} \\
\text { solid }\end{array}$ & $2.3 \mathrm{~V}$ & & $667 \mu \mathrm{W} \mathrm{h} \mathrm{cm}{ }^{-2}$ \\
\hline & & & & $\begin{array}{l}\text { Current density } \\
=10 \mu \mathrm{A} \mathrm{cm}^{-2}\end{array}$ & - & \\
\hline $\begin{array}{l}\mathrm{Li}_{4 / 3} \mathrm{Ti}_{5 / 3} \mathrm{O}_{4} \text { thin } \\
\text { film }\end{array}$ & $\mathrm{Li}$ & $\mathrm{Li}_{4 / 3} \mathrm{Ti}_{5 / 3} \mathrm{O}_{4}$ & $1 \mathrm{M} \mathrm{LiPF}_{6} / \mathrm{EC}-\mathrm{DMC}$ & $1.55 \mathrm{~V}$ & Thickness—230 nm & $57 \mu \mathrm{A} \mathrm{h} \mathrm{cm}^{-2} \mu \mathrm{m}^{-1}$ \\
\hline \multirow[t]{2}{*}{$\begin{array}{l}\mathrm{Li}_{4} \mathrm{Ti}_{5} \mathrm{O}_{12} \text { thin } \\
\text { film }\end{array}$} & $\mathrm{Li}$ & $\mathrm{Li}_{4} \mathrm{Ti}_{5} \mathrm{O}_{12}$ & $1 \mathrm{M} \mathrm{LiPF}_{6} / \mathrm{EC}-\mathrm{EMC}$ & $1.55 \mathrm{~V}$ & $230 \mathrm{~nm}$ & $53 \mu \mathrm{A} \mathrm{h} \mathrm{cm}{ }^{-2} \mu \mathrm{m}^{-1}$ \\
\hline & & & & $\begin{array}{l}\text { Current density } \\
=10 \mu \mathrm{A} \mathrm{cm}^{-2}\end{array}$ & & \\
\hline
\end{tabular}

Disadvantages include their degradation at high operating temperatures, need for protective circuitry for charging of cells, capacity loss or thermal runaway when overcharged, and venting when crushed $[73,90,91]$. Specific challenges to the implementation of lithium-ion thin-film, thick-film and microbattery battery technologies to portable electronics include present limitations on intercalation of sufficiently high volumes of lithium and the irreversibility of the structural changes that result from the intercalation [6]; integration of fabrication techniques with CMOS techniques; development of 
economical substrates other than platinum or platinum coated substrates [92]; management of capacity fade with cycling [93] and reduction of interface degradation [94, 95].

Other challenges for application of lithium and lithiumion thin-film cells to portable electronics are low current and capacity due to reduced amounts of active material available in the cells. To address low current and capacity limitations of both lithium and lithium-ion planar thin-film cells, workers have investigated (1) thin-film silicon-zirconium-silver [96] cells, which have enhanced capacity retention during cycling; (2) thick-film nickel metal hydride cells, which allow for increased values of power and energy/unit area [2], and (3) 3D microbatteries that have increased capacity due to increased area and electro-active layers [8]. Although conventional surface MEMS techniques can achieve out-of-plane geometry with acceptable tolerances, they do not readily support structures that have component dimensions perpendicular to the plane of the wafer (that are large compared to the thickness of the wafer), which would be necessary to increase the battery active material for longer device lifetimes.

Design strategies for hybrid battery systems have been investigated to enhance the power supply lifetime and ultimate lifetime of the host device. One strategy [97-99] involved comparison of three methods of designing a power supply. The first approach of power supply design included specification of a single, aggregate power supply resulting in the use of a single electrochemistry and cell size. The second approach included specification of several power supplies, by a priori division of power sources by power range, and the third approach involved specification of an arbitrary number of power 'bundles', based on available space in the host device. The battery selections provided by each approach were compared according to final power supply mass and/or volume and lifetime for a given application. Application of this strategy to a gas chromatograph [98] resulted in power supply masses and volumes for approach 2 that were 47.1 and $43.8 \%$, and 48.3 and $87.5 \%$ for approaches 1 and 3, respectively.

\subsection{Microcombustors, turbine and heat engines}

Microturbine systems spanning miniature combustors, turbines, compressors, recuperators/regenerators and generators (figure 2 [100]) have been proposed as alternatives to microbatteries because of their potentially high power densities. Some advantages of microturbines are multi-fuel capabilities, greater energy efficiencies, reduced emissions and relatively easy fabrication [100]. One disadvantage of microturbines is that the cycle efficiency (without use of a recuperator) is lower than reciprocating engines, in applications with a high load factor and/or high rotation speeds. In cases where high rotational speeds are required, gear reduction equipment and direct drive high frequency alternators coupled with stationary rectifiers may be required, resulting in increased complexity, size and mass of the system.

These systems have captured the attention of the Department of Energy's Office of Energy Efficiency and Renewable Energy, which has, in recent years, undertaken a multi-year program to develop advanced microturbine systems

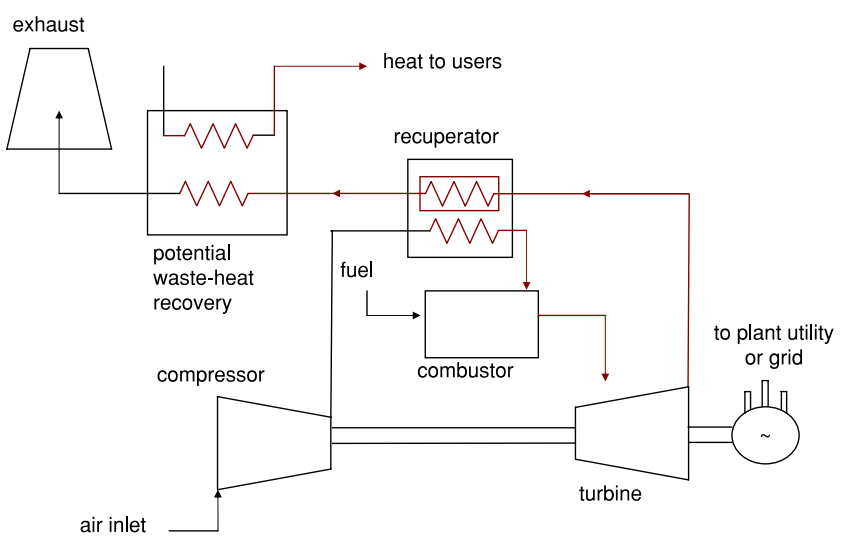

Figure 2. Schematic of a typical microcombustion system.

up to $1000 \mathrm{~kW}$ from existing microturbines systems which offer $25-75 \mathrm{~kW}$ [100]. This plan also calls for a minimum of fuel-to-electricity conversion efficiency of 40\%; $\mathrm{NO}_{x}$ emissions less than $7 \mathrm{ppm}$ for natural gas machines; $11000 \mathrm{~h}$ of operation between major overhauls, and a minimum $45000 \mathrm{~h}$ of service life [20, 100].

Most of the work in microturbines has focused on enhancement of individual system components for overall system gain, e.g. miniaturization of turbines and speed of ball bearings, which limit the power and efficiency of the system, and blade profile losses [100]. Miniaturization of combustors to the microscale, which is constrained by residence time for complete combustion, high rates of heat transfer, and material and thermodynamic cycle constraints have also been studied [20]. Hydrocarbon-air combustors have been investigated [101], but hydrocarbon-air reactions can be 5-50 times slower than hydrogen-air reactions [17], and for hydrocarbon fuels, such as propane and ethylene, power densities decrease by a factor of 10 as a result of reaction time [17].

Management of $\mathrm{NO}_{x}$ emissions is critical for hydrocarbon combustion systems. Several workers have investigated lean, premixed combustion systems, wherein a small amount of fuel is mixed with air prior to combustion to maintain a low flame temperature, while still achieving complete combustion, to reduce $\mathrm{NO}_{x}$ emissions $[17,102]$. Problems associated with premixed combustion include flame blow-out, flash-back and pressure oscillations in the combustion chamber [102, 103].

Implementation of MEMS manufacturing techniques for microcombustors is also challenging because the materials commonly used for MEMS fabrication, single-crystal silicon and glass, cannot achieve appropriate strengths or lifetimes at combustor operating temperatures [103]. A more suitable material, i.e. a silicon nitride ceramic [17], has been investigated for these applications, using both mechanical micromachining and MEMS machining technologies, though significant redesign of the structure and use of a catalyst and/or preheating before ignition is necessitated with this material [11].

Development of microcombustors for photovoltaic (PV) microsystems has also been investigated for application to MEMS devices [11, 12, 15, 27-29]. Table 4 provides novel 
Table 4. Novel thermophotovoltaic (TPV) cell data on combustion chamber size, hydrogen flow rate and approximate power density based on an assumed package size of $1 \mathrm{~cm}^{3}$.

\begin{tabular}{|c|c|c|c|c|c|}
\hline Composition & $\begin{array}{l}\text { Combustion } \\
\text { chamber volume }\end{array}$ & $\begin{array}{l}\text { Open circuit } \\
\left(V_{\mathrm{OC}}\right) / \text { short circuit } \\
\text { current }\left(I_{\mathrm{SC}}\right)\end{array}$ & $\begin{array}{l}\text { Flow rate of } \\
\text { hydrogen } \\
\left(\mathrm{g} \mathrm{h}^{-1}\right)\end{array}$ & Power & $\begin{array}{l}\text { Power density } \mathrm{W} \mathrm{cm}^{-3} \\
\text { (assuming entire } \\
\text { package }=1 \mathrm{~cm}^{3} \text { ) }\end{array}$ \\
\hline \multirow{3}{*}{$\begin{array}{l}\text { Microcylindrical silicon } \\
\text { combustor, 9-layer } \\
\text { dielectric filter, GaSb } \\
\text { photovoltaic array }\end{array}$} & \multirow[t]{3}{*}{$0.113 \mathrm{~cm}^{3}$} & \multirow[t]{3}{*}{-} & \multirow[t]{3}{*}{4.2} & $\begin{array}{l}0.92 \mathrm{~W}(0.4 \mathrm{~mm} \\
\text { wall thickness) }\end{array}$ & 0.92 \\
\hline & & & & $\begin{array}{l}0.78 \mathrm{~W}(0.6 \mathrm{~mm} \\
\text { wall thickness })\end{array}$ & 0.78 \\
\hline & & & & $\begin{array}{l}0.57 \mathrm{~W} \text { (0.8 mm } \\
\text { wall thickness) }\end{array}$ & 0.57 \\
\hline $\begin{array}{l}\mathrm{SiC} \text { emitter, 9-layer } \\
\text { dielectric filter, GaSb } \\
\text { photovoltaic array }\end{array}$ & $0.113 \mathrm{~cm}^{3}$ & $2.28 \mathrm{~V} / 0.59 \mathrm{~A}$ & 4.2 & $1.02 \mathrm{~W}$ & 1.02 \\
\hline $\begin{array}{l}\text { SiC emitter, 9-layer } \\
\text { dielectric filter, GaInAsSb } \\
\text { photovoltaic array }\end{array}$ & $0.113 \mathrm{~cm}^{3}$ & $2.32 \mathrm{~V} / 0.52 \mathrm{~A}$ & 4.2 & $1.45 \mathrm{~W}$ & 1.45 \\
\hline $\begin{array}{l}\text { Microtube combustor, } \\
\text { emitters, photovoltaic } \\
\text { cells }\end{array}$ & $\begin{array}{l}0.113 \mathrm{~cm}^{3} \\
\text { Entire package } \\
\text { volume }=1.0 \mathrm{~cm}^{3}\end{array}$ & - & 3.88 & $4.4 \mathrm{~W}$ & 4.4 \\
\hline Microtube combustor & - & $2.3 \mathrm{~V} / 0.4 \mathrm{~A}$ & 4.2 & $0.81 \mathrm{~W}(\mathrm{SiC})$ & 0.81 \\
\hline $\begin{array}{l}\text { (SiC or platinum), } \\
\text { emitters, photovoltaic } \\
\text { cells }\end{array}$ & & & & $\begin{array}{l}0.78 \mathrm{~W} \\
\text { (platinum) }\end{array}$ & 0.78 \\
\hline
\end{tabular}

thermophotovoltaic (TPV) cell data on combustion chamber size, hydrogen flow rate and approximate power density based on an assumed package size of $1 \mathrm{~cm}^{3}$. These systems typically consist of a heat source, a microflame tube combustor made of a selective emitter material, a dielectric filter and a photovoltaic array [28]. In these systems, hydrogen is often chosen as the fuel because of its high heating value and short reaction time. The process of operation for these devices consists of burning a hydrogen-air mixture in the microcombustor, which results in photon emission. The filter in turn recycles the photons with energies lower than the bandgap of the PV cells to the microcombustor and transmits the photons with energies greater than the bandgap of the PV cells. When the photons with high enough energies encounter the PV cell array, free electrons are released, thereby producing electrical power.

Microcombustor designs for PV systems must maintain a balance between sustained combustion and generation of sufficient heat [28]. The reduction of the size of the combustor results in a higher surface area-to-volume ratio that allows for increased radiation power and higher power density for the entire PV system. However, combustion ignition and quench reactions are subdued by large amounts of heat loss resulting from large surface area to volume ratios. Therefore, workers are currently investigating the factors influencing heat loss and uniform temperature through and along the wall of the flame tube, such as flame tube dimensions, the hydrogen to air ratio and flow rate [28].

\subsection{Microfuel cells}

Fuel cells have also been considered for powering MEMS devices. Fuel cells are comprised of an anode (hydrogen fuel source) and cathode (usually oxygen from air) separated by an electrolyte. Fuel cells are typically distinguished by the electrolyte used. If an acid electrolyte is used, the anode releases electrons, producing hydrogen ions $\left(\mathrm{H}^{+}\right.$, protons). The hydrogen ions pass through the electrolyte, while the electrons pass through an electrical circuit. Hydrogen ions and electrons react with oxygen to form water. Conversely, if an alkaline electrolyte is used, alkali hydroxyl $\left(\mathrm{OH}^{-}\right)$ ions (produced at the cathode) react with hydrogen at the anode, to produce electrons and water [104]. Types include solid oxide fuel cells (SOFCs), molten carbonate fuel cells (MCFCs), phosphoric acid fuel cells (PAFCs) and polymer electrolyte membrane fuel cells (PEMFCs). Advantages of fuel cell technology are (1) competitive energy density and specific energy values, (2) low emissions, (3) quiet operation and (4) ability to serve as both heat and power systems. Table 5 [24, 105-112] summarizes information on several novel microfuel cells.

PEMFCs have been rigorously studied, because of their resistance to mechanical vibrations (no electrolyte leakage), relatively small size (due to thin electrolyte membrane) and low operational temperatures $\left(20-100^{\circ} \mathrm{C}\right)$ in comparison to other fuel cell systems [22]. PEMFCs operate at low temperatures and thus require catalysts on the electrodes. The best and most commonly used catalyst for PEMFCs is platinum, which is costly. The majority of the work on the development of planar fuel cell technologies has focused on patterning technology for fabrication of microflow fields and membrane electrodes, design studies of integrated flow fields, material compatibility, interconnection of planar single cells and assembly processes that are compatible with MEMS fabrication techniques [105, 106, 109, 110, 112-114].

Both direct and indirect methanol fuel cells have also been investigated for microscale implementation. Direct methanol fuel cells produce six electrons when methanol is mixed with water. Indirect fuel cells require a reformer to produce hydrogen molecules from methanol. Both indirect and direct methanol fuel cells experience fuel crossover when hydrogen 
Table 5. Microfuel cell type, electrolyte, current, voltage, dimensions and power density.

\begin{tabular}{|c|c|c|c|c|}
\hline Type & Electrolyte & Current/voltage & Dimensions & Power/area \\
\hline $\begin{array}{l}\text { Polymer electrolyte } \\
\text { fuel cell (PEFC) })^{1}\end{array}$ & Polymer & $0.8 \mathrm{~V}$ & $5 \mathrm{~mm} \times 15 \mathrm{~mm}$ & $90 \mu \mathrm{W} \mathrm{cm}{ }^{-2}$ \\
\hline $\begin{array}{l}\text { Proton exchange } \\
\text { membrane planar fuel cell }{ }^{2}\end{array}$ & Polymer & $\begin{array}{l}1.5 \mathrm{~V} \\
40 \mathrm{~mA}\end{array}$ & $\begin{array}{l}1 \mathrm{~cm} \times 1 \mathrm{~cm} \text { and } \\
200 \mu \mathrm{m} \text { thickness }\end{array}$ & $80 \mathrm{~mW} \mathrm{~cm}^{-2}$ \\
\hline $\begin{array}{l}\text { Microdirect methanol fuel cell } \\
(\mathrm{DMFC}) \text { with } \\
\text { membrane-electrode } \\
\text { assemblies (MEA) }{ }^{3}\end{array}$ & $\begin{array}{l}\text { Nafion proton } \\
\text { exchange } \\
\text { membrane }\end{array}$ & $\begin{array}{l}37 \mathrm{~mA} \mathrm{~cm}^{-2} \\
0.22 \mathrm{~V}\end{array}$ & $25.1 \mathrm{~mm} \times 25.1 \mathrm{~mm} \times 0.5 \mathrm{~mm}$ & $8 \mathrm{~mW} \mathrm{~cm} \mathrm{~cm}^{-2}$ \\
\hline $\begin{array}{l}\text { Microdirect ethanol } \\
\text { fuel cell }\end{array}$ & $\begin{array}{l}\text { Nafion } 115 \\
\text { membrane }\end{array}$ & $0.26 \mathrm{~V}$ & $1 \mathrm{~cm} \times 1 \mathrm{~cm} \times 0.0627 \mathrm{~cm}$ & $8.1 \mathrm{~mW} \mathrm{~cm}^{-2}$ \\
\hline $\begin{array}{l}\text { Microdirect methanol fuel cells } \\
(\mu \mathrm{DMFC}) \text { with methanol-resistant } \\
\text { membrane-electrode assemblies } \\
(\mathrm{MEA})^{5}\end{array}$ & $\begin{array}{l}\text { Nafion } 112 \\
\text { membrane }\end{array}$ & $\begin{array}{l}90 \mathrm{~mA} \mathrm{~cm}^{-2} \\
\text { at } 0.3 \mathrm{~V}\end{array}$ & Active area- $-1.625 \mathrm{~cm}^{2}$ & $\begin{array}{l}34 \mathrm{~mW} \mathrm{~cm}^{-2} \\
\text { at } 0.33 \mathrm{~V} \\
62.5 \mathrm{~mW} \mathrm{~cm}^{-2} \\
\text { at } 40{ }^{\circ} \mathrm{C} \\
100 \mathrm{~mW} \mathrm{~cm}^{-2} \\
\text { at } 60^{\circ} \mathrm{C}\end{array}$ \\
\hline $\begin{array}{l}\text { Microproton exchange } \\
\text { membrane fuel cell } \\
(\mathrm{PEMFC})\end{array}$ & Polymer & $\begin{array}{l}\sim 460 \mathrm{~mA} \mathrm{~cm}{ }^{-2} \\
\quad \text { at } 1.0 \mathrm{~V}\end{array}$ & $\begin{array}{l}\text { Channel: width }=500 \mu \mathrm{m} \\
\text { and depth }=300 \mu \mathrm{m} \\
\text { Rib width }=500 \mu \mathrm{m}\end{array}$ & $\sim 142 \mathrm{~mW} \mathrm{~cm}^{-2}$ \\
\hline Metallic PEM fuel cell & Polymer & $\begin{array}{l}250 \mathrm{~mA} \mathrm{~cm}^{-2} \\
\text { at } 0.6 \mathrm{~V}\end{array}$ & $\begin{array}{l}\text { Total thickness }=2.6 \mathrm{~mm} \\
\text { reaction area }=4 \mathrm{~cm}^{2} \\
\text { bipolar plate } \\
\text { area }=16 \mathrm{~cm}^{2}\end{array}$ & $\sim 195 \mathrm{~mW} \mathrm{~cm}^{-2}$ \\
\hline $\begin{array}{l}\text { Single chamber } \\
\text { solid oxide fuel cell }\end{array}$ & $\mathrm{Ce}_{0.8} \mathrm{Gd}_{0.1} \mathrm{O}_{1.95}$ & $0.7-0.77 \mathrm{~V}$ & $\begin{array}{l}\text { Microcell active } \\
\text { area }=0.051 \mathrm{~cm}^{2}\end{array}$ & $17 \mathrm{~mW} \mathrm{~cm}^{-2}$ \\
\hline $\begin{array}{l}\text { Direct methanol } \\
\text { fuel cell, PEM }\end{array}$ & Polymer & $\begin{array}{l}0.35 \mathrm{~mA} \mathrm{~cm}^{-2} \\
\text { at } 0.74 \mathrm{~V}\end{array}$ & $\begin{array}{l}\text { Silicon plates: } \\
\text { top }=260 \mu \mathrm{m} \\
\text { bottom }=150 \mu \mathrm{m} \text {, } \\
\text { depth }=80 \mu \mathrm{m}\end{array}$ & $0.20 \mathrm{~mW} \mathrm{~cm}^{-2}$ \\
\hline
\end{tabular}

or methanol molecules flow through the electrolyte and react with oxygen, reducing the overall flow of electrons and generation of electricity. Application of membrane-electrode assemblies (MEAs) with modified support backing has been used to diminish this effect [115].

Balancing the amount of water in the electrolyte to maintain conductivity, without flooding the electrode, or blocking the pores in the electrode or gas diffusion layer is another critical design constraint for PEMFCs. Proof-of-concept devices have been described, which demonstrate techniques for water management and microfluidic subsystems. For example, a microscale direct methanol fuel cell that included a silicon wafer with arrays of etched holes selectively coated with a nonwetting agent for collecting water at the cathode has been developed [116]. In this cell, a silicon membrane micropump is used to pump excess water back to the anode and a passive liquid gas separator is used for $\mathrm{CO}_{2}$ removal.

Others have investigated utilization of steel plates as bipolar plates, with photochemically etched flow fields, to enhance sealing of the cells and reduce contact resistance associated with silicon-based direct methanol microfuel cells [24]. Fabrication of microfuel cells via MEMS fabrication techniques has also been an area of interest, wherein in-plane anodic and cathodic microchannels (as opposed to two separate substrates) have been fabricated using photolithography, deep reactive ion etching, and electron beam deposition [117]. MEMS ion etching has also been used for gas channel preparation and formation of porous silicon layers for membrane-electrode assemblies for reduction of diffusion paths, support of bulk flow and enhancement of efficiency of material transport [118]. Hybrid micro- and macromachining processes have also been utilized to optimize reliability of the microfuel cell structure [119]. Stainless steel bipolar plates with microfeature flow channels have been investigated for enhanced cell drainage [110], while planar electrodes fabricated from nanoimprint technology have been explored for the creation of fine patterns on the PEM, as an alternative to graphite-based porous electrodes [113].

Despite the numerous advances in PEM direct methanol fuel cells, high performance hinges on advances in delivery of microfluidic systems, water and temperature management; current collector design; minimization of contact resistance between components, and development of solid proton exchange membranes, such as nafion, which tend to change shape depending on the degree of humidification and degrade with temperature fluctuations.

Other workers involved in fabrication of microscale solid oxide fuel cells (SOFC) have identified several areas for enhanced performance of this technology: (1) minimization of ionic resistance of the electrolyte; (2) reduction of stresses incurred during fabrication and operation, which is influenced by thermal mechanical stability, reliability and heat transfer within the cell, and (3) thermal isolation to prevent heat loss since SOFC operate at temperatures of several hundred degrees centigrade $[23,26]$. 
Table 6. Commercial solar cell system performance characteristics.

\begin{tabular}{|c|c|c|c|c|c|c|}
\hline $\begin{array}{l}\text { Panel dimensions } \\
\text { (inches) }\end{array}$ & $\begin{array}{l}\text { Price per } \\
\text { panel }\end{array}$ & $\begin{array}{l}\text { Material } \\
\text { composition }\end{array}$ & Peak voltage $(\mathrm{V})$ & $\begin{array}{l}\text { Peak } \\
\text { current }\end{array}$ & $\begin{array}{l}\text { Peak } \\
\text { power }(\mathrm{W})\end{array}$ & $\begin{array}{l}\text { Power/area } \\
\left(\mathrm{W} \mathrm{m}^{-2}\right)\end{array}$ \\
\hline $29.5 \times 12.9 \times 1.3$ & $\$ 181.00$ & CIS/thin film & $\begin{array}{l}15.6 \text { (peak) } \\
12 \mathrm{~V} \text { (nominal) }\end{array}$ & $1.29 \mathrm{~A}$ & 20 & 0.006 \\
\hline $58.1 \times 26 \times 1.4$ & $\$ 499.18$ & Crystalline silicon & 16.7 & $6.60 \mathrm{~A}$ & 110 & 0.011 \\
\hline $50.9 \times 13 \times 1.3$ & $\$ 234.00$ & $\begin{array}{l}\text { CIS (copper indium } \\
\text { diselenide) }\end{array}$ & $\begin{array}{l}16.6 \text { (peak) } \\
12 \text { (nominal) }\end{array}$ & $2.41 \mathrm{~A}$ & 40 & 0.006 \\
\hline $56 \times 25 \times 2$ & $\$ 534.00$ & $\begin{array}{l}\text { Polycrystalline silicon } \\
\text { no. of cells: } 36 \text { in series } \\
\text { module efficiency: } \\
13.1 \%\end{array}$ & 17.1 & 6.43 & 110 & 0.012 \\
\hline $50.9^{\prime \prime} \times 12.9^{\prime \prime} \times 1.3^{\prime \prime}$ & $\$ 229.00$ & $\begin{array}{l}\text { CIS (copper indium } \\
\text { diselenide) }\end{array}$ & $\begin{array}{l}15.8 \text { (peak) } \\
12 \text { (nominal) }\end{array}$ & 2.28 & 36 & 0.006 \\
\hline
\end{tabular}

\section{Regenerative energy harvesting and MEMS}

Powering devices from scavenged ambient energy from the environment presents an opportunity for replacing or extending the lifetime of common power sources such as batteries, and is the primary area of interest of the present review. Photovoltaics, thermoelectrics and kinetic approaches are first discussed, followed by an in-depth review of piezoelectric devices, which are perhaps one of the most promising sets of technologies among vibration-based technologies for application to MEMS devices.

\subsection{Solar cells}

Solar power systems are one of the most commonly considered strategies of 'energy harvesting'. These systems consist of solar arrays and signal processing circuitry. Power from solar cells results from the photovoltaic effect, which is the direct conversion of incident light into electricity [120]. Photons generated from sunlight are absorbed (producing proton holes), stimulating current orthogonal to the flow of proton holes. The advantages of solar array systems include their ease of integration, modularity, lack of emission or noise, lack of moving parts and use of a readily available resource, i.e. sunlight. Disadvantages of solar systems include the additional signal processing circuitry required to provide high quality continuous current at a specific voltage; variability in quality and amount of power generation and relatively large surface area required for arrays of cells. Other disadvantages of PV systems that are prohibitive to MEMS applications are low conversion efficiencies and high cost, in addition to the spotty availability of sunlight.

Most commercially manufactured solar cells are based on multi-crystalline silicon or monocrystalline silicon with cell and module efficiencies of $10-16 \%$, while novel fabrication techniques demonstrated in the laboratories have efficiencies of about $24 \%$ (one metamorphic GaInP/GaInAs/Ge threejunction cell with $40 \%$ efficiency at 240 suns [121]), but are costly [30, 32, 33, 106, 120, 122-140]. Common commercial and novel solar PV panels, along with their respective power capabilities, are presented in table 6 [141-143] and table $7[130,132,144-151]$. Table 7 provides the material composition, open circuit voltage, short circuit current, power per unit area and power conversion efficiency of a number of novel solar cells. Material compounds such as III-V compounds, e.g. gallium arsenide (GaAs), indium phosphide (InP) and gallium antimonide (GaSb), are being explored as materials for PV cells, but are both expensive and contain either toxic or scarce elements [120]. One additional problem with thin-film solar cells is that, in order to reach higher power density values, larger surface areas are required. To address some of these issues, workers have fabricated various types of systems. These include: PV devices in series to achieve high voltage delivery for application to electrostatic MEMS [30], systems comprised of microphotovoltaic arrays coupled with a microwave antenna [31], thermal integral microgeneration (TIMGen) systems for use with solar-or fuelderived heat [32] and PV arrays subjected to laser light of different wavelengths for application to laser-or LED-driven PV systems [33]. Microcrystalline silicon and polysilicon have also been investigated for use in the middle and bottom cells of nip (n-type, intrinsic, p-type layers) triple-junction cells [137]. Fundamental transport mechanisms that influence single-junction nip $\mu \mathrm{C}-\mathrm{Si}$ structures where the intrinsic layer is deposited by the hot-wire CVD technique [152, 153] have also been undertaken.

The efficiencies and fabrication techniques for thin-film solar cells based on $\mathrm{CdTe}$ and $\mathrm{CuGaInSe}_{2}$ have improved, despite the forecast lack of abundance of some constituent materials, which may limit large-scale production of these cells. Also, the use of organic materials such as dyes, semiconductor polymers $[130,133,136,154-156]$ that incorporate both micro- and nanotechnology, along with tandem/multi-junction devices [149, 151, 154, 157, 158], have resulted in pronounced enhanced efficiencies (table 7). The typical power densities of novel solar cells [141-143] are comparable with some thin- and thick-film lithium and lithiumion batteries [2, 3, 9, 74-89] as detailed in figure 3; the voltages produced by solar cells require significant processing to achieve values realized by battery technology.

\subsection{Thermoelectric power}

Generation of electricity via thermal gradient, the so-called Seeback effect, is another form of regenerative power supply proposed for powering portable MEMS devices. Novel thermoelectric devices are presented in table 8 $[52,153,159-175]$. A typical system is shown in figure 4 
Table 7. Novel solar cell data detailing material composition, open circuit voltage, short circuit current, power provided per unit area and power conversion efficiency.

\begin{tabular}{|c|c|c|c|c|c|c|}
\hline Active area & $\begin{array}{l}\text { Material } \\
\text { composition }\end{array}$ & $\begin{array}{l}\text { Open circuit } \\
\text { voltage/short circuit } \\
\text { current }\end{array}$ & $\begin{array}{l}\text { Fill } \\
\text { factor }(\%)\end{array}$ & $\begin{array}{l}\text { Power/area } \\
\mathrm{mW} \mathrm{cm} \mathrm{cm}^{-2}\end{array}$ & $\begin{array}{l}\text { AM simulated } \\
\text { solar intensity } \\
\mathrm{mW} \mathrm{cm}\end{array}$ & $\begin{array}{l}\text { Power } \\
\text { conversion } \\
\text { efficiency }(\%)\end{array}$ \\
\hline $0.0725 \mathrm{~cm}^{2}$ & $\mathrm{GaAlAs} / \mathrm{GaAs}$ & $0.7 \mathrm{~V} / 3.7 \mathrm{~mA}$ & 69 & 35.72 & 100 & 24.6 \\
\hline $0.15 \mathrm{~cm}^{2}$ & $\begin{array}{l}\text { 3-methylthiophene } \\
\text { onto textured n-Si } \\
\text { wafers }\end{array}$ & $0.26 \mathrm{~V} / 2.0 \mathrm{~mA}$ & 0.24 & 3.47 & 30 & 0.42 \\
\hline Not given & $\begin{array}{l}\text { Dye-sensitized } \\
\text { nanocrystalline } \mathrm{TiO}_{2}\end{array}$ & $\begin{array}{l}0.344 \mathrm{~V} / \\
5.93 \mathrm{~mA} \mathrm{~cm}^{-2}\end{array}$ & 45 & 2.04 & 100 & 0.91 \\
\hline $4.0 \mathrm{~cm}^{2}$ & Crystalline silicon & $\begin{array}{l}0.696 \mathrm{~V} / \\
42.0 \mathrm{~mA} \mathrm{~cm}^{-2}\end{array}$ & 83.6 & 29.23 & 100 & 24.7 \\
\hline $\begin{array}{l}1 \mathrm{~cm}^{2} \\
\text { thick }=99 \mu \mathrm{m}\end{array}$ & Multicrystalline & $\begin{array}{l}0.664 \mathrm{~V} / \\
37.7 \mathrm{~mA} \mathrm{~cm}^{-2}\end{array}$ & 80.9 & 25.03 & 1000 & 20.3 \\
\hline $\begin{array}{l}1 \mathrm{~cm}^{2} \\
\text { thick }=218 \mu \mathrm{m}\end{array}$ & Multicrystalline & $\begin{array}{l}0.653 \mathrm{~V} / \\
38.8 \mathrm{~mA} \mathrm{~cm}^{-2}\end{array}$ & 78.6 & 25.34 & 1000 & 19.9 \\
\hline $\begin{array}{l}1 \mathrm{~cm}^{2} \\
\text { thick }=220 \mu \mathrm{m}\end{array}$ & $\begin{array}{l}\text { Phosphorus gettered } \\
\text { multicrystalline silicon }\end{array}$ & $\begin{array}{l}0.660 \mathrm{~V} / 39.8 \\
\mathrm{~mA} \mathrm{~cm}\end{array}$ & 80.7 & 26.27 & - & 21.2 \\
\hline $\begin{array}{l}0.25 \mathrm{~cm}^{2} \\
\text { thick }=354.87 \mu \mathrm{m}\end{array}$ & $\begin{array}{l}\text { AlGaAs/Si monolithic } \\
\text { Tandem solar cell }\end{array}$ & $1.5 \mathrm{~V} / 23 \mathrm{~mA} \mathrm{~cm}^{-2}$ & 77.2 & 34.5 & 1 sun & 19.9 \\
\hline $\begin{array}{l}\text { top }=0.25 \mathrm{~cm}^{2} \\
\text { bottom }=0.33 \mathrm{~cm}^{2}\end{array}$ & $\begin{array}{l}\text { Three-terminal } \\
\text { monolithic GaAs/Si } \\
\text { cascade solar cell }\end{array}$ & $\begin{array}{l}0.857 \mathrm{~V} / \\
30.7 \mathrm{~mA} \mathrm{~cm}^{-2}\end{array}$ & 77.9 & 26.31 & 135.3 & - \\
\hline
\end{tabular}

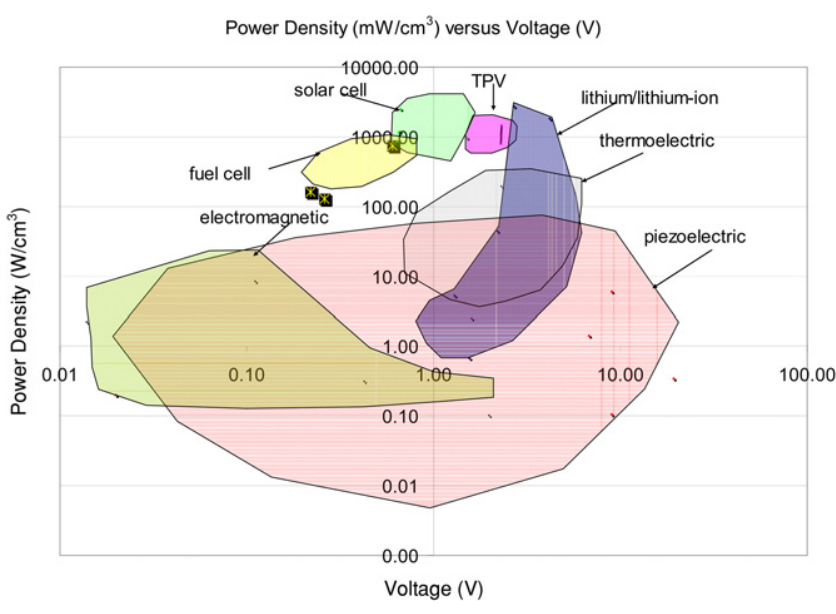

Figure 3. Plot of power density versus voltage for common regenerative and lithium/lithium-ion power supply strategies.

[153] (only one cell), with n- and p-type semiconductor legs connected electrically in series by metal strips and thermally in parallel [153]. Thermocouples are examples of thermoelectric elements that have a temperature difference between two junctions of dissimilar materials that results in an electrical current. In figure 4 , heat from a source at a temperature, $T_{w}$, is conducted to an electrically insulated heat exchanger with a thermal conductance, $K_{1}$. Heat flows from the source to the hot side of the heat exchanger at a rate $Q_{\mathrm{h}}$ and from the exchanger to the thermocouple. Electrical current subjected to a resistive load of $R_{1}$ is produced from the temperature differential between the hot and cold sides of the thermocouple. Heat flows from the cold junction at a rate of $Q_{\mathrm{c}}$, at a temperature of $T_{\mathrm{C}}$, to the cold side of the heat exchanger that has a conductance of $K_{2}$ [153].

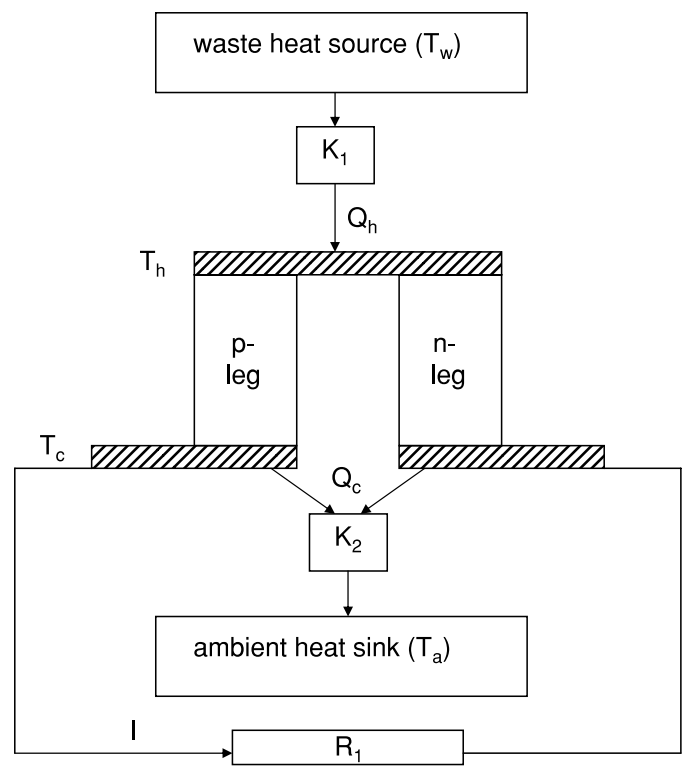

Figure 4. Schematic of a typical thermoelectric system.

The advantages of thermoelectric generators are that they are reliable, solid state and have long operation times with little noise and emissions $[153,165]$. Yet, commercial realization of thermoelectric generators has been delayed due to material problems associated with thermocouple modules. These modules are fabricated from intermetallic compounds such as $\mathrm{Bi}_{2} \mathrm{Te}_{3}, \mathrm{~Pb}-\mathrm{Te}$ and $\mathrm{Si}-\mathrm{Ge}$, which have intrinsically low melting and/or decomposition temperatures, low energy conversion efficiency and toxic content and are presently scarce [51]. Limited energy conversion efficiencies and operational temperatures have restricted the usage of thermoelectric devices 
Table 8. Open circuit output voltage, power, power density and power per unit area values for novel thermoelectric devices.

\begin{tabular}{|c|c|c|c|c|c|}
\hline Composition & $\Delta T$ & Dimensions & $\begin{array}{l}\text { Open circuit } \\
\left(V_{\mathrm{OC}}\right)\end{array}$ & Power & $\begin{array}{l}\text { Power/area or } \\
\text { power density }\end{array}$ \\
\hline $\begin{array}{l}\text { BiTe thermopile, } 158 \\
\text { thermocouples per stage }\end{array}$ & - & $\begin{array}{l}\text { Thermopile size: } \\
0.67 \mathrm{~cm} \times 0.84 \mathrm{~cm} \times 0.18 \mathrm{~cm}\end{array}$ & $1.6 \mathrm{~V}$ & $250 \mu \mathrm{W}$ & $2.47 \mathrm{~mW} \mathrm{~cm}^{-3}$ \\
\hline $\begin{array}{l}\text { Coiled generator fabricated } \\
\text { using screen print technique }\end{array}$ & 5 & $\begin{array}{l}1 \mathrm{~cm}^{2} \\
2 \mathrm{~cm}^{2}\end{array}$ & $\begin{array}{l}0.8 \mathrm{~V} \\
1.6 \mathrm{~V}\end{array}$ & $\begin{array}{l}0.8 \mu \mathrm{W} \\
1.6 \mu \mathrm{W}\end{array}$ & $0.8 \mu \mathrm{W} \mathrm{cm}^{-2}$ \\
\hline $\begin{array}{l}\text { Polymer-based wafer level } \\
\text { fabrication ( } 51 \text { thermocouples) }\end{array}$ & 20 & $\begin{array}{l}\text { Area }=0.26 \mathrm{~cm}^{2} \\
\text { Height }=150+10 \mu \mathrm{m}\end{array}$ & - & - & $12.0 \mathrm{nW} \mathrm{cm}{ }^{-2}$ \\
\hline $\begin{array}{l}\text { PbTe-based, cross-plane } \\
\text { quantum-dot superlattice (QDSL) } \\
\text { unicouple devices fabricated } \\
\text { from nanostructured thick films }\end{array}$ & 220 & $\begin{array}{l}\text { Length }=95 \mu \mathrm{m} \\
\text { Cross sectional } \\
\text { area }=4 \mathrm{~mm}^{2}\end{array}$ & - & $89 \mathrm{~mW}$ & $2.2 \mathrm{~W} \mathrm{~cm}^{-2}$ \\
\hline $\begin{array}{l}\text { Thermoelectric generator coupled } \\
\text { with catalytic butane combustor } \\
34 \text { thermocouples }\end{array}$ & - & $\begin{array}{l}\text { Each element }= \\
0.95 \mathrm{~mm} \times 0.95 \mathrm{~mm} \times 2.0 \mathrm{~mm} \\
\text { Total volume }=0.955 \mathrm{~cm}^{3}\end{array}$ & $2.31 \mathrm{~V}$ & $184 \mathrm{~mW}$ & $192.67 \mathrm{~mW} \mathrm{~cm}^{-3}$ \\
\hline $\begin{array}{l}\text { Generator fabricated using } \\
\text { polysilicon surface } \\
\text { micromachining }\end{array}$ & 5 & $\begin{array}{l}\text { Area }=1 \mathrm{~cm}^{2} \\
\text { Thickness }= \\
400 \mathrm{~nm}\end{array}$ & $5 \mathrm{~V}$ & $1 \mu \mathrm{W}$ & $1.0 \mu \mathrm{W} \mathrm{cm}^{-2}$ \\
\hline $\begin{array}{l}\text { Micro Sb-Bi thermocouple strips } \\
\text { embedded within a } 50 \mu \mathrm{m} \text { thick } \\
\text { flexible epoxy film ( } 100 \text { pairs of } \\
\text { thermocouples) }\end{array}$ & 30 & $16 \mathrm{~mm} \times 20 \mathrm{~mm} \times 0.05 \mathrm{~mm}$ & 0.25 & - & - \\
\hline
\end{tabular}

in applications such as radioisotope thermoelectric generators [176]. Realization of power generating thermoelectric devices for MEMS applications are limited due to the lack of large temperature gradients $\left(>10^{\circ} \mathrm{C}\right)$ in small device volumes $\left(<1 \mathrm{~cm}^{3}\right)$ [162]. Therefore, most research has focused on optimization of thermoelectric materials and module geometry $[162,173]$. Oxide materials such as $\mathrm{Ca}_{2.7} \mathrm{Bi}_{0.3} \mathrm{Co}_{4} \mathrm{O}_{9}(\mathrm{Co}-$ 349 ) for p-type and $\mathrm{La}_{0.9} \mathrm{Bi}_{0.1} \mathrm{NiO}_{3}$ (Ni-113) for n-type materials [51]; filled skutterudite materials for high temperature thermoelectric applications [159]; V-VI compounds $\mathrm{Bi}_{2} \mathrm{Te}_{3}$ and $(\mathrm{Bi}, \mathrm{Sb})_{2} \mathrm{Te}_{3}$ [161] and nanoarchitectured devices made of $\mathrm{Bi}_{2} \mathrm{Te}_{3}$ and BiSbTe nanobundled elements [165] have been investigated as alternative materials. N-type materials that operate in the temperature range of 300-1272 K and p-type materials that operate in ranges from 300 to $975 \mathrm{~K}$ have also been fabricated [52, 160, 163, 170, 177].

Proof-of-concept devices of hybrid thermoelectric systems and new methods for evaluation of thermoelectric generator efficiency [153] such as a two-stage solar concentrator for combined heat and thermoelectric power generation [50] and a thermoelectric generator coupled with a thermo-acoustic refrigerator [168], have also been investigated.

\subsection{Vibration energy harvesting systems}

Recently energy harvesting from external mechanical excitation has become an area of interest. A plot of power density versus output voltage for common forms of regenerative power production is provided in figure 4 [55, 58, 120, 142, 178-194]. This plot indicates that vibration-based energy harvesting devices have power density values that are comparable to some other power sources such as thin- and thick-film lithium and lithium-ion batteries. Electrostatic energy systems are not included in this plot since the voltages produced by most electrostatic generators are significantly out of range $(0.01-100.00 \mathrm{~V}$ in the plot) of those plotted. Also, pulsed piezoelectric generators have not been included in figure 4 for two reasons: first, their power density values are typically outside of the range of values plotted, e.g. $0.151 \mathrm{MW} \mathrm{cm}^{-3}[187,188,195]$, and second, the pulse generators that reach power densities of these values have not yet been realized for portable electronics and MEMS devices. We have chosen to focus the remainder of this review on vibration-based energy harvesting with an emphasis on piezoelectric energy harvesting because much of the work is in its infancy and many of these technologies can be incorporated into hybrid power systems with existing commercial technologies. Furthermore, the purpose of this discussion is not to suggest that vibration-based energy scavenging is superior to other forms of regenerative energy systems, but rather to elucidate the applications and areas of needed investigation for enhancement of piezoelectric energy harvesting devices.

The use of vibration energy harvesting devices is an ever-expanding area of interest for wireless, self-powered microsystems and macroscaled devices. There are a number of opportunities for energy harvesting via vibration. Table 9 $[47,48,55,196]$ includes the acceleration $\left(\mathrm{m} \mathrm{s}^{-2}\right)$ and peak frequency $(\mathrm{Hz})$ values of a number of low level vibrating structures. In this section, an overview of general kinetic energy theory will be presented, followed by a comparison of electrostatic, electromagnetic and piezoelectric energy harvesting technologies.

3.3.1. Kinetic energy harvesting theory. Kinetic energy harvesting involves conversion of mechanical energy into electrical energy, wherein environmental displacements (kinetic energy source) are coupled with a transduction mechanism. In these systems, a mechanical component is attached to an inertial frame, which serves as a fixed reference as depicted in figure 5. In figure 5, energy is generated from the relative displacement or mechanical strain between the fixed inertial 
Table 9. Acceleration magnitude and frequency of potential sources of vibration among common commercial devices.

\begin{tabular}{lll}
\hline $\begin{array}{ll}\text { Vibration source } \\
\text { Car engine }\end{array}$ & $\begin{array}{l}\text { Acceleration } \\
\left(\mathrm{m} \mathrm{s}^{-2}\right)\end{array}$ & $\begin{array}{l}\text { Frequency } \\
(\mathrm{Hz})\end{array}$ \\
$\begin{array}{l}\text { compartment } \\
\text { Base of 3-axis } \\
\text { machine tool }\end{array}$ & 12 & 200 \\
$\begin{array}{l}\text { Blender casing } \\
\begin{array}{l}\text { Clothes dryer } \\
\text { Person tapping }\end{array}\end{array}$ & 6.4 & 70 \\
their heel & 3 & 121 \\
$\begin{array}{l}\text { Car instrument } \\
\text { panel }\end{array}$ & 3 & 1 \\
$\begin{array}{l}\text { Door frame just } \\
\text { after door closes }\end{array}$ & 3 & 13 \\
$\begin{array}{l}\text { Small microwave oven } \\
\text { HVAC vents in } \\
\text { office building }\end{array}$ & 2.5 & 125 \\
$\begin{array}{l}\text { Windows next to } \\
\text { a busy road }\end{array}$ & $0.2-1.5$ & 60 \\
$\begin{array}{l}\text { CD on notebook } \\
\text { computer }\end{array}$ & 0.7 & 100 \\
$\begin{array}{l}\text { Second story floor } \\
\text { of busy office }\end{array}$ & 0.6 & 75 \\
\hline
\end{tabular}

frame and the attached mass. In the case of electromagnetic devices, the transduction mechanism is velocity, while in electrostatic devices it is relative position. The piezoelectric transduction mechanism employs the strain, e.g. deformation of the device, for generation of electricity. In general, optimal output energy from kinetic energy harvesting devices is obtained when the coupling between the kinetic energy source and transduction mechanism is optimized [197]. Models predicting the power generated from vibration systems typically are comprised of (but are not limited to) inertial spring and mass systems, where each transduction mechanism exhibits a different damping characteristic.

The model most commonly used to describe kinetic energy harvesting systems is based on a resonant secondorder spring and mass system with a linear damper as shown in figure 5 [198]. Because the damping mechanism is proportional to the velocity in this model, it (in theory) best represents an electromagnetic device. Thus, this model can provide good information on resonant generators, and some aspects of it can be used for the design of the other two transducer applications, namely piezoelectric and electrostatic. In this model [198-200], vibration from the inertial frame, e.g. the housing, induces movement of the mass, $m$, which is out of phase with the generator housing. The inertial frame is excited by an external sinusoidal vibration of the form, $y(t)=Y \sin (\omega t)$ that drives the generator. This model only applies to systems where the mass of the vibrating source (housing) is much greater than the mass of the generator and systems where the vibration source is relatively unaffected by the movement of the generator. Specifically, this model applies to systems where energy is to be scavenged from the inertial frame. The net displacement of the mass is $z(t)$, and the differential equation that describes the movement of the mass

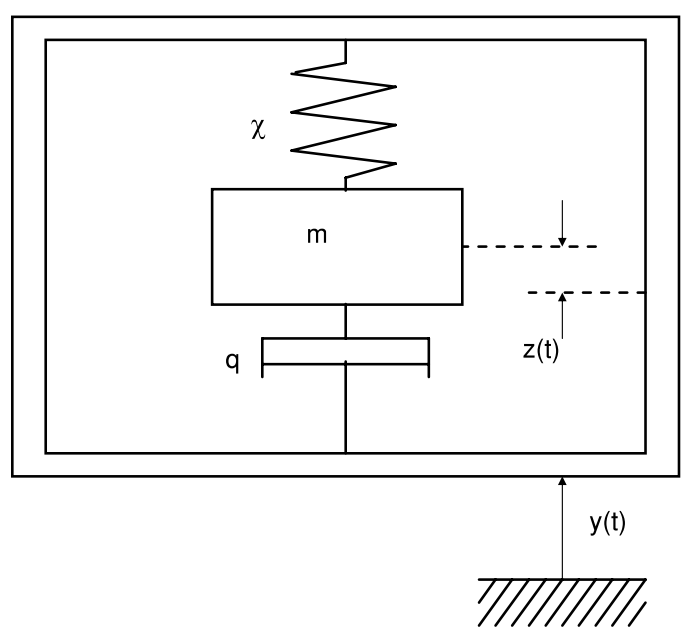

Figure 5. Schematic for a typical kinetic energy scavenging system.

with respect to the generator housing is expressed as

$$
m \ddot{z}(t)+q \dot{z}(t)+\chi z(t)=-m \ddot{y}(t) .
$$

In equation (1) $[197,198], m$ is the seismic mass, $q$ is the damping coefficient, $t$ is time and $\chi$ is the spring stiffness. In equation (1), the damping coefficient is comprised of both the parasitic losses $q_{\mathrm{p}}$ and electrical energy extracted by the transduction mechanism, $q_{\mathrm{e}}$.

The steady-state solution for the displacement of the mass is given by

$$
z(t)=\frac{\omega^{2}}{\sqrt{\left(\frac{\chi}{m}-\omega^{2}\right)^{2}+\left(\frac{q \omega}{m}\right)^{2}}} Y \sin (\omega t-\phi),
$$

where $\phi$ is the phase angle, expressed as

$$
\phi=\tan ^{-1}\left(\frac{q \omega}{\chi-\omega^{2} m}\right) .
$$

The instantaneous power, $p(t)$, generated from the resonant system is the product of the force on the mass $(-m \ddot{y}(t))$ and the mass's velocity $(\dot{y}(t)+\dot{z}(t))$ :

$$
p(t)=-m \ddot{y}(t)[\dot{y}(t)+\dot{z}(t)] .
$$

Mechanical power is converted to electrical power when damping is present. For a sinusoidal excitation vibration, the electrical power generated, $P(t)$, by the system is given by

$$
P(t)=\frac{m \zeta_{\mathrm{t}} Y^{2}\left(\frac{\omega}{\omega_{\mathrm{n}}}\right)^{3} \omega^{3}}{\left[1-\left(\frac{\omega}{\omega_{\mathrm{n}}}\right)^{2}\right]^{2}+\left[2 \zeta_{\mathrm{t}} \frac{\omega}{\omega_{\mathrm{n}}}\right]^{2}} .
$$

In equation (5), $\zeta_{\mathrm{t}}$ is the transducer damping ratio $\left(\zeta_{\mathrm{t}}=\right.$ $\left.q / 2 m \omega_{\mathrm{n}}\right), \omega_{\mathrm{n}}$ is the natural frequency of the system, $Y$ is the amplitude of vibration and $\omega$ is the excitation frequency. Several conclusions may be drawn from the model. First, the maximum output power occurs at the natural frequency of the generator [198], e.g. when $\omega_{\mathrm{n}}=\sqrt{k / m}$, namely

$$
P_{\max }=\frac{m Y^{2} \omega_{\mathrm{n}}^{3}}{4 \zeta_{\mathrm{t}}}
$$


Also it can be concluded from equation (6) that the value of the maximum power is indeed finite, and that reduction of the damping factor results in increased mass displacement, which is ultimately limited by the size and geometry of the device. Second, if the natural frequency of the generator housing is set equal to the seismic mass frequency, the maximum power generated is limited by the movement of the seismic mass. Thus, the maximum power can be expressed in terms of maximum distance the seismic mass can move, $Z_{\max }$ :

$$
P_{\max }=m \zeta_{\mathrm{t}} \omega_{\mathrm{n}}^{3} Z_{\max }^{2}
$$

Third, for applications where the frequencies of vibration are well defined and concentrated around one point, a low damping factor will provide higher peak responses and power generation. Fourth, if the fundamental vibration frequency varies over time, a higher damping factor is needed to increase the bandwidth of the generator. Fifth, power generation is proportional to the cube of the vibration frequency.

The power available from the vibrating beam structure is also limited by undesirable parasitic mechanical damping, $\zeta_{\mathrm{p}}$, such as air resistance. Equation (8) [197] is an expression for power in terms of both the parasitic, $\zeta_{\mathrm{p}}$, and electrical, $\zeta_{\mathrm{e}}$, damping ratios:

$$
P=\frac{\zeta_{\mathrm{e}}}{4\left(\zeta_{\mathrm{p}}+\zeta_{\mathrm{e}}\right)^{2}} m Y^{2} \omega_{\mathrm{n}}^{3}
$$

Others have also expressed power in terms of the excitation acceleration magnitude of the input vibration:

$$
P=\frac{\zeta_{\mathrm{e}}}{4 \omega_{\mathrm{n}}\left(\zeta_{\mathrm{e}}+\zeta_{\mathrm{p}}\right)^{2}} m A^{2}
$$

In equation (9), $A$ is excitation acceleration and can be computed from $A=\omega_{\mathrm{n}}^{2} Y$. In equation (9) power is inversely proportional to the natural frequency of the seismic mass. Equations (8) and (9) can be used to draw several conclusions regarding power generation from piezoelectric systems [48]. First, if the acceleration magnitude is constant or decreasing with frequency the converter should be designed to resonate at the lowest fundamental frequency in the input spectrum. Second, since the mass of the converter is proportional to the power generated, the converter should be as large as possible, while meeting size constraints of the system. Third, the power generated by a vibrating system is maximized when the electrical damping ratio, $\zeta_{\mathrm{e}}$, is equal to the mechanical damping ratio (parasitic), $\zeta_{\mathrm{p}}$. Fourth, power was greatly diminished in cases where $\zeta_{\mathrm{p}}$ was greater than $\zeta_{\mathrm{e}}$, but was only slightly reduced for cases where $\zeta_{\mathrm{e}}$ was greater than $\zeta_{\mathrm{p}}$. In other words, a highly damped system will slightly under-perform as long as the majority of the damping is electrically induced.

\subsubsection{Comparison of electromagnetic, electrostatic and} piezoelectric energy harvesting transduction mechanisms. Electromagnetic materials produce electricity from the motion of a magnetic field relative to a conductive coil, which causes current to flow in the coil [201-203]. Typically, the electricity is generated by either the relative movement of the magnet and coil, or due to the changes in the magnetic field [197, 198] Therefore, the amount of electricity generated can be a function of magnetic field strength, relative motion velocity and the number of turns of the coil. In most systems, the magnets are attached to the cantilever structure and act as inertial masses. The expressions for power defined in section 3.3.1 can be determined by incorporating the appropriate electromagnetic expression for the damping ratio, $q_{\mathrm{e}}$. In figure 5, $q$ represents the electromagnetic transduction mechanism, e.g. the magnet and coil arrangement. An expression for the damping ratio for electromagnetic devices has been determined to be [203]

$$
q_{\mathrm{e}}=\frac{(N \ell B)^{2}}{R_{\text {load }}+R_{\text {coil }}+\mathrm{j} \omega L_{\text {coil }}},
$$

where $N$ is the number of turns in the generator coil, $\ell$ is the side length of the coil (assumed to be a square) and $B$ is the flux density. $R_{\text {load }}$ and $R_{\text {coil }}$ are the load and coil resistance, respectively, and $L_{\text {coil }}$ is the coil inductance. In equation (10), $R_{\text {Load }}$ can be adjusted to produce maximum power, e.g. achieve the case where $q_{\mathrm{e}}$ is equal to $q_{\mathrm{p}}$. The expression for the optimal value for $R_{\mathrm{Load}}, R_{\mathrm{Load}}^{\prime}$, has been determined to be [199]

$$
R_{\text {Load }}^{\prime}=R_{\text {coil }}+\frac{(N \ell B)^{2}}{q_{\mathrm{p}}} .
$$

Also the maximum average power provided to the load, $R_{\text {Load }}^{\prime}$, is given by

$$
P_{\text {Load-max }}=\frac{m A^{2}}{16 \zeta_{\mathrm{p}} \omega_{\mathrm{n}}}\left(1-\frac{R_{\text {coil }}}{R_{\text {Load }}^{\prime}}\right) .
$$

A number of wafer-scale and macroscale devices have been fabricated, and details of these devices are provided in table 10 [178, 189, 200, 203-211].

Electromagnetic energy harvesting technology is well established and is utilized in many electrical generators. Furthermore, these systems require no input voltage source to initiate power generation, though the voltage generated is usually between 0.1 and $0.2 \mathrm{~V}$. Hence transformers are usually needed to meet voltage requirements for MEMS applications. Macroscaled, high performance bulk magnets, and multi-turn and macroscale coils are readily available, but there remain challenges for fabrication of MEMS scale systems due to the poor properties of planar magnets [197]. Also, the number of turns that can be achieved with planar coils are limited, in addition to the restricted amplitudes of vibration that result in commensurately reduced velocities in MEMS electromagnetic devices. Lastly, the assembly and alignment of wafer-scale (sub-millimeter) electromagnetic systems remain a challenge for implementation to MEMS devices [197].

Electrostatic generators are comprised of two conductive plates that are electrically isolated via air, vacuum or an dielectric insulator (capacitor), which move relative to one another [212]. There are two modes of electrostatic energy conversion: one where the charge on the capacitor is constrained, while the voltage increases and the capacitance decreases, and the other when the voltage across the capacitor is constrained, while the charge moves from the capacitor as 
Table 10. Output voltage, power and power density data for novel electromagnetic devices.

\begin{tabular}{|c|c|c|c|c|c|c|}
\hline$P(\mu \mathrm{W})$ & $F(\mathrm{~Hz})$ & $A\left(\mathrm{~m} \mathrm{~s}^{-2}\right)$ & Volume & $\begin{array}{l}\text { Power density } \\
\left(\mathrm{mW} \mathrm{cm}^{-3}\right)\end{array}$ & Voltage & Description \\
\hline 0.3 & 4400 & 382 & $0.0054 \mathrm{~cm}^{3}$ & 0.056 & - & GaAs, polyimide \\
\hline 530 & 322 & - & $0.24 \mathrm{~cm}^{3}$ & 2.21 & $\sim 14 \mathrm{mVrms}$ & Steel \\
\hline $0.4 \mathrm{nW}$ & 700 & 12.4 & $2.1 \mathrm{~cm}^{3}$ (simulated) & $190.5 \mathrm{nW} \mathrm{cm}^{-3}$ & - & Silicon \\
\hline 180 & 322 & 2.7 & $0.84 \mathrm{~cm}^{3}$ & 0.214 & - & Steel \\
\hline $45 \mathrm{nW}$ & 360 & $\begin{array}{l}3.4 \mu \mathrm{m} \\
\text { displacement }\end{array}$ & $\begin{array}{l}7 \mathrm{~mm} \times 7 \mathrm{~mm} \times 4 \mathrm{~mm} \\
\text { magnet and } \\
13 \mathrm{~mm} \times 13 \mathrm{~mm} \\
\text { membrane }\end{array}$ & - & $\sim 21 \mathrm{mV}$ & $\begin{array}{l}\text { Silicon-based technology- } \\
\text { a fixed micromachined coil } \\
\text { and a movable magnet }\end{array}$ \\
\hline 830 & 110 & $\begin{array}{l}95.5 \\
\text { (simulated) }\end{array}$ & $1 \mathrm{~cm}^{3}$ & 0.830 & - & Copper/brass \\
\hline 7000 & 35 & - & $9 \mathrm{~cm}^{3}$ & 0.778 & - & LTCC/beryllium/copper \\
\hline 46 & 52 & 0.5 & $0.15 \mathrm{~cm}^{3}$ & 0.306 & $428 \mathrm{mVrms}$ & $\begin{array}{l}4 \text { magnets arranged on an } \\
\text { etched cantilever with a } \\
\text { wound coil }\end{array}$ \\
\hline $2-25$ & Resonant & - & $0.25 \mathrm{~cm}^{3}$ & $0.008-0.10$ & 2 Vrms & $\begin{array}{l}\text { Air-cored tubular } \\
\text { architecture and flexible } \\
\text { translator bearing }\end{array}$ \\
\hline 412 & 149.3 & - & $0.05 \mathrm{~cm}^{3}$ & 8.24 & $111.2 \mathrm{mV}$ & $\begin{array}{l}\text { In-plane rotary generator, } \\
\text { consisting: multi-layer } \\
\text { planar copper microcoil } \\
\text { and mutipolar hard magnet }\end{array}$ \\
\hline 0.5 & 9500 & 1.92 & - & - & - & Silicon \\
\hline
\end{tabular}

the capacitance decreases [48]. The plates are charged via an external source such as a battery with a voltage, $V$. The charging of the plates creates equal and opposite charges on the plates, which results in stored charge when the voltage source is disconnected. Electrostatic transduction operates via a constant force, the $F_{\mathrm{E}}$ damping effect, so-called Coulomb damping [190]. The power dissipated by these devices, e.g. the energy dissipated within the damper, is calculated from the product of the force and distance and is expressed as [213]

$$
P_{\mathrm{E}}=\frac{4 Y F_{\mathrm{E}} \omega \omega_{\mathrm{c}}^{2}}{2 \pi}\left[\frac{1}{\left(1-\omega_{\mathrm{c}}^{2}\right)^{2}}-\left(\frac{F_{\mathrm{E}}}{m Y \omega^{2} \omega_{\mathrm{c}}} U\right)^{2}\right]^{1 / 2},
$$

where $\omega_{\mathrm{c}}=\omega / \omega_{\mathrm{n}}$ and $U=\sin \left(\pi / \omega_{\mathrm{c}}\right) /\left[1+\cos \left(\pi / \omega_{\mathrm{c}}\right)\right]$. The optimum damping force for an electrostatic energy harvesting generator is given by [197]

$$
F_{\mathrm{E}, \mathrm{opt}}=\frac{Y \omega^{2} m}{\sqrt{2}} \frac{\omega_{\mathrm{c}}}{\left|\left(1-\omega_{\mathrm{c}}^{2} U\right)\right|} .
$$

The capacitance of these devices can be expressed as [197]

$$
C=\frac{Q_{\mathrm{E}}}{V_{\mathrm{E}}}
$$

where $C$ is capacitance in farads, $Q_{\mathrm{E}}$ is the charge on the plate in coulombs and $V_{\mathrm{E}}$ is the voltage on the plates in volts. For a parallel plate capacitor, the capacitance is given by

$$
C=\varepsilon \frac{A_{\mathrm{E}}}{d_{\mathrm{E}}},
$$

where $\varepsilon$ is the permittivity of the material between the plates in units of $\mathrm{F} \mathrm{m}^{-1}, A_{\mathrm{E}}$ is the area of the plates in $\mathrm{m}^{2}$ and $d_{\mathrm{E}}$ is the separation between the plates in meters.
The voltage across a parallel plate capacitor and the energy stored in the capacitor are given by

$$
V_{\mathrm{E}}=\frac{Q_{\mathrm{E}} d_{\mathrm{E}}}{\varepsilon_{o} A_{\mathrm{E}}}
$$

where $\varepsilon_{o}$ is the permittivity of free space and the energy

$$
E_{\mathrm{E}}=0.5 Q_{\mathrm{E}}^{2} / C .
$$

For the constrained charge case, the perpendicular force between the plates is given by

$$
F_{\mathrm{E}}=\frac{0.5 Q_{\mathrm{E}} 2 d_{\mathrm{E}}}{\varepsilon A_{\mathrm{E}}} .
$$

Also, for the case where the voltage is constrained, the perpendicular force between the plates is given by

$$
F_{\mathrm{E}}=\frac{0.5 \varepsilon A_{\mathrm{E}} V_{\mathrm{E}}^{2}}{d_{\mathrm{E}}} .
$$

The harvested energy is derived from the work done against the electrostatic force between the plates. Electrostatic generators can be grouped into three categories: (1) inplane overlap varying, (2) in-plane gap closing and (3) outof-plane gap closing [47, 48, 183, 196], wherein the three technologies can be operated via charge or voltage constrained modes. In general, the voltage constrained approach provides the most energy. However, the energy produced from the charge constrained approach can approach that of the voltage constrained approach if a capacitor is incorporated in parallel with an energy harvesting capacitor. In-plane gap closing techniques generally offer the highest output power, followed by out-of-plane closing and then in-plane overlap varying [183]. 
Table 11. Output voltage, power and power density data for novel electrostatic energy harvesting devices.

\begin{tabular}{|c|c|c|c|c|c|c|c|}
\hline$P(\mu \mathrm{W})$ & $F(\mathrm{~Hz})$ & $A\left(\mathrm{~m} \mathrm{~s}^{-2}\right)$ & Mass (g) & $\begin{array}{l}\text { Volume } \\
\left(\mathrm{cm}^{3}\right)\end{array}$ & Voltage & $\begin{array}{l}\text { Power } \\
\text { density }\end{array}$ & Material \\
\hline 58 & 4.76 & 0.5 & 1200 & - & 24 & - & Aluminum/polyester \\
\hline 8 & 2520 & - & - & 75 & - & $8 \mathrm{nW} \mathrm{cm}^{-3}$ & Silicon \\
\hline 36 & 6 & 1 & 780 & - & - & - & Aluminum/polyester \\
\hline 3.7 & 30 & 50 & 0.1 & 750 & - & $4.9 \mathrm{nW} \mathrm{cm}^{-3}$ & Silicon/pyrex \\
\hline $\begin{array}{l}110 \\
\text { (simulated) }\end{array}$ & 120 & 2.25 & - & 1000 & - & $0.11 \mu \mathrm{W} \mathrm{cm}^{-3}$ & Silicon \\
\hline $97 \mathrm{mV}$ & 28000 & 1395 & - & - & - & - & Aluminum/gold/glass \\
\hline 0.12 & 45 & 0.08 & - & - & - & - & Metal \\
\hline 0.065 & 4200 & 766 & $2 \times 10^{-4}$ & - & 0.4 & - & Gold/silicon \\
\hline 6 & 10 & 3.9 & - & 800 & $200 V_{p-p}$ & $7.5 \mathrm{nW} \mathrm{cm}^{-3}$ & Polymer/glass \\
\hline 80 & 30 & 40 & - & Area $=5.5 \mathrm{~cm}^{2}$ & $220 \mathrm{~V}$ & $14.5 \mu \mathrm{W} \mathrm{cm}-2$ & Glass and silicon \\
\hline $0.3 \mathrm{~J} /$ cycle & - & - & 0.5 proof mass & - & $250 \mathrm{~V}$ & - & Quartz and silicon \\
\hline 24 & 10 & - & - & Area $=0.56 \mathrm{~cm}^{2}$ & $2.3 \mathrm{kV}$ & $42.9 \mu \mathrm{W} \mathrm{cm}^{-2}$ & Silicon and quartz \\
\hline
\end{tabular}

Electrostatic devices have tremendous capability for integration into microsystems, via the use of silicon micromachining fabrication techniques, and most of the work has focused on in-plane and out-of-plane capacitors [183]. A table of novel technologies is presented in table 11 [47, 183, 190, 204, 212, 214-219]. Power generated by the motion of the human body has been the focus of several workers, such as power generation from the left ventricular wall motion of a laboratory animal used to power a cardiac pacemaker [214] and non-resonant force Coulomb force generators, that derive energy from non-uniform, non-periodic human motion for biosensor applications [190, 220, 221].

In general, the energy density of electrostatic generators can be increased by reduction of capacitor spacing (typically of the order of nm to $\mu \mathrm{m}$ ) or by reduction of the capacitor surface area [197].

Electrostatic generators are easily fabricated for MEMS applications, yet there are several challenges for realization of commercial devices. First, these devices require an input charge or voltage. This does not present a problem for devices that can provide an input voltage via batteries or electrets, but can pose a problem for devices where these devices are not suitable. Second, the output impedance and voltage of these electrostatic devices are high, making them less suitable for power supply devices due to reduced amounts of available current resulting from high output voltage. Third, the limited current supply necessitates custom circuitry and signal processing for implantation as energy harvesting devices. Fourth, the parasitic capacitances within the structure can result in reduced efficiency. Lastly, in wafer-scale applications, there are problems associated with electrode shorting.

Piezoelectric materials produce an electrical charge when subjected to mechanical loads. An undisturbed molecular model of a piezoelectric material is shown in figure 6(a) [222]. Here the gravity centers of the positive and negative charges of each molecule are arranged so that their respective charges cancel one another, until a load $F$ is applied as shown in figure 6(b). The applied load causes the molecular structure to deform, which in turn causes a separation of the positive and negative gravity centers, resulting in dipoles, which polarize the material as shown in figure $6(\mathrm{c})$. The polarized material

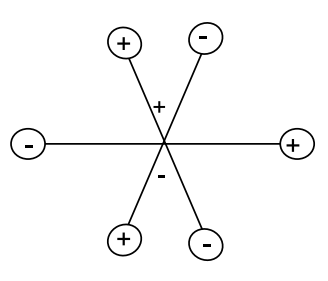

a)

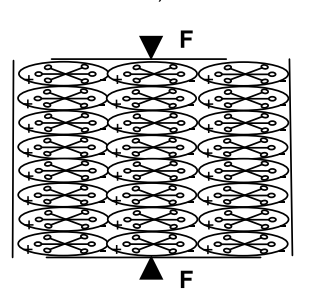

c)

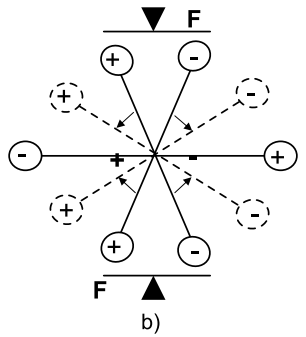

b)

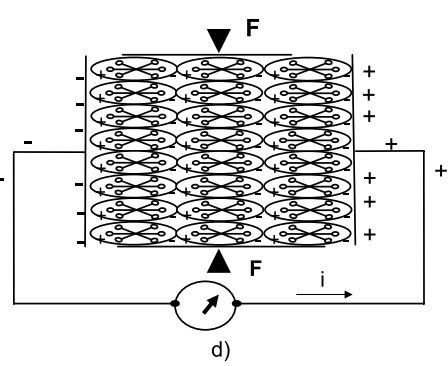

Figure 6. (a) Undisturbed molecular model of a piezoelectric material, where the molecules are arranged so that their respective charges cancel one another. (b) Molecular structure subjected to an applied load $F$ at both ends, where structural deformation causes a separation of positive and negative gravity centers creating dipoles. (c) A polarized piezoelectric material is depicted, wherein facing poles on the inside of the material mutually cancel each other, while positive and negative poles appear at the surface of the material. (d) Neutralization of the polarization effect by the flow of free charge.

consists of poles on the inside of the material that face and mutually cancel each other, while positive and negative poles appear at the surface of the material [222]. The polarization effect is neutralized by the flow of free charge as shown in figure 6(d).

The damping coefficient for piezoelectric transduction is expressed as

$$
q_{\mathrm{e}}=\frac{2 m \omega_{\mathrm{n}}^{2} k^{2}}{2 \sqrt{\omega_{\mathrm{n}}^{2}+\left(1 /\left(R_{\mathrm{load}} C_{\text {load }}\right)^{2}\right)}} .
$$

In equation (21), $k$ is the piezoelectric material electromechanical coupling factor and $C_{\text {Load }}$ is the load capacitance. Maximum power is achieved with $\zeta_{\mathrm{e}}$ and $\zeta_{\mathrm{p}}$ are equal, which results 
in the following expression for the optimal load:

$$
R_{\mathrm{opt}}=\frac{1}{\omega_{\mathrm{n}} C} \frac{2 \zeta_{\mathrm{p}}}{\sqrt{4 \zeta_{\mathrm{p}}^{2}+k^{4}}}
$$

The three transduction techniques for energy harvesting can be compared based on device efficiency, which is given by

$$
\eta=\frac{U_{\mathrm{out}}}{U_{\mathrm{in}}}
$$

where $U_{\text {out }}$ is the energy delivered to the electrical load and $U_{\text {in }}$ is the input energy from the excitation vibrations/cycle. In addition to comparison by efficiency, the coupling coefficient, $k$, is another parameter used to compare the performance of the transduction methods. The coupling coefficient describes how efficiently the external vibration energy is converted to energy stored within the generator. The transmission coefficient, $\lambda$, which is mathematically equal to the expression for efficiency provided in equation (23) [47, 197], is also used to compare vibration-based energy harvesting technologies. The maximum transmission coefficient can be expressed as a function of coupling coefficient:

$$
\lambda_{\max }=\frac{k}{4-2 k^{2}},
$$

and is dependent upon the resistive load that is selected to produce maximized values. The maximum power from any of the transducers can be calculated from the expression [47]

$$
P_{\max , \lambda}=\lambda_{\max } \omega U_{\text {in }} .
$$

Equations (24) and (25) can be evaluated for each transduction technique from different expressions for the coupling coefficient [47]. The coupling coefficient for the electromagnetic generator is given by

$$
k^{2}=\frac{(B \ell)^{2}}{\chi L_{\text {coil }}} .
$$

The coupling coefficient for piezoelectric generators is expressed as

$$
k^{2}=\frac{d^{2} E_{\mathrm{y}}}{\varepsilon},
$$

where $d$ is the piezoelectric strain coefficient and $E_{\mathrm{y}}$ is Young's modulus $(\mathrm{Pa})$. The coupling coefficients for electrostatic generators are nonlinear and dependent on the geometry and operating conditions of the device [197]. However, an expression for an out-of-plane parallel plate capacitor operating in constant charge mode is given by [197]

$$
k^{2}=\frac{V_{\mathrm{in}}^{2} C_{\max }^{2}}{V_{\mathrm{in}}^{2} C_{\max }^{2}+m \omega^{2} z^{2} C(z)} .
$$

In equation (28), $V_{\text {in }}$ is the input voltage, $z$ is the displacement of the top electrode and $C_{\max }$ is the maximum capacitance. From this expression it is evident that the coupling coefficient varies with displacement, and hence throughout the cycle. Electromagnetic and piezoelectric generators share the same expression for maximum energy density, which is expressed as

$$
\tilde{E}=\frac{k^{2} \rho\left(Q_{\mathrm{M}} A\right)^{2}}{4 \omega},
$$

where $\rho$ is the density of the proof mass material, $Q_{\mathrm{M}}$ is the mechanical quality factor of the generator and $A$ is the magnitude of the acceleration of the excitation vibration. The average power density for an electrostatic generator can be calculated from

$$
\tilde{P}_{\text {ave }}=f \frac{\rho\left(Q_{\mathrm{M}} A\right)^{2}}{2 \omega^{2}} \int_{1}^{2} k(t) \mathrm{d} t,
$$

where $f$ is the frequency of the generator. Values of transmission and coupling coefficients of the three transduction techniques have been compared [47]. In these studies, the transmission and coupling coefficient contours were plotted against the frequency and area enclosed by the conductor loop. Since the electromagnetic coefficients are dependent on the design of the device, the electromagnetic properties that were assumed in the study were $7.5 \mathrm{~g} \mathrm{~cm}^{-3}$ and $0.1 \mathrm{~T}$ for the mass density and magnetic flux density, respectively. Given these values, the coefficients and power densities of piezoelectric and electromagnetic devices were comparable. However, for different design characteristics of the electromagnetic device, this may not be the case. In the same study, the average coupling coefficient was plotted versus the frequency and gap of a $1 \mathrm{~cm}^{2}$ parallel plate with a mass density of $7.5 \mathrm{~g} \mathrm{~cm}^{-3}$ and $Q_{\mathrm{M}}$ of 30 . Although these values were comparable to the electromagnetic and piezoelectric values, the amplitudes of the displacement values were unrealistically high compared to the minimum capacitor separation gap. In another study [55], the maximum achievable energy densities for piezoelectric, electromagnetic and electrostatic transduction were 35.4, 24.8 and $4 \mathrm{~mJ} \mathrm{~cm}^{-3}$, respectively. In this study, the piezoelectric device was made of PZT-5H, the electromagnetic device had a magnetic flux density of $0.25 \mathrm{~T}$ and the electrostatic device had a supply voltage of $3 \times 10^{7} \mathrm{~V} \mathrm{~m}^{-1}$.

The remainder of this review focuses on piezoelectric energy harvesting devices because piezoelectric energy harvesting devices are the simplest (of the three vibration-based devices, e.g. electromagnetic, electrostatic and piezoelectric) means of scavenging power directly from the structural vibration for several reasons. First, piezoelectric devices directly convert vibration energy to a voltage. Second, numerous additional components and complex geometries are not required for realization of workable devices [197]. Therefore, these devices are relatively simple in comparison to the other vibration-based energy harvesting devices to fabricate. Third, piezoelectric generators are well suited for application to both micro- and macroscaled devices, as evidenced by the available thin- and thick-film fabrication techniques [223-237] and macroscaled [58, 186-188, 238-249] devices, as opposed to electromagnetic devices, which are not easily fabricated on the microscale. Fourth, these devices do not require an input voltage as opposed to electrostatic devices. Also, piezoelectric devices can deliver relatively high output voltages (though at low electrical currents), as opposed to electromagnetic generators that may require transformers to meet applications with 
required voltages higher than $\sim 2$ V. Since production of power via piezoelectric devices requires strain and deformation of the material, the performance, lifetime and transduction efficiency are dependent upon the material properties.

\section{Piezoelectrics for energy harvesting}

\subsection{Electromechanical governing equations and constants}

Piezoelectric materials produce a voltage across them when a mechanical stress or strain is applied, or vice versa. The linear constitutive equations that describe the mechanical and electrical behavior of piezoelectric materials are [47, 211, 250]

$$
\begin{gathered}
S_{i j}=s_{i j k l}^{\mathrm{E}} T_{k l}+d_{k i j} E_{k} \\
D_{i}=d_{i k l} T_{k l}+\varepsilon_{i k}^{\mathrm{T}} E_{k} .
\end{gathered}
$$

In equations (31) and (32) subscripts $i, j, k$ and $l$ take values of 1,2 , and 3. $S$ and $T$ are strain and stress tensors, respectively. $T$ has SI units of $\mathrm{N} \mathrm{m}^{-2}$ and represents stresses that are induced by the mechanical and electrical effects. $D$ and $E$ are the electric displacement and electric field vectors, with SI units of $\mathrm{C} \mathrm{m}^{-2}$ and $\mathrm{V} \mathrm{m}^{-1}$, respectively. Also, $s^{\mathrm{E}}$ is the elastic compliance matrix evaluated at a constant electric field with SI units of $\mathrm{m}^{2} \mathrm{~N}^{-1}, d$ is a matrix of piezoelectric strain coefficients with SI units of $\mathrm{m} \mathrm{V}^{-1}$ and $\varepsilon^{\mathrm{T}}$ is a matrix of permittivity values that are evaluated at a constant stress with SI units of $\mathrm{N} \mathrm{V}^{-2}$. In equations (31) and (32) $d$ represents the charge created by a given force in the absence of an electric field (short circuit electrical condition), or the deflection caused by an applied voltage in the absence of an applied force (stressfree mechanical condition) [251].

Thermal effects have also been included in the constitutive equations [252, 253] for piezoelectric materials. These models are especially important for ferroelectric relaxor-type and composite materials because they behave nonlinearly with temperature and frequency. The thermo-piezoelectric constitutive equations at constant temperature and voltage that incorporate the coefficient of thermal expansion and pyroelectric effects are as follows:

$$
\begin{gathered}
S_{\varpi}=s_{\varpi \beta}^{E, T}(T) \sigma_{\beta}+d_{\varpi m}^{\mathrm{T}}(T) E_{\mathrm{m}}+\alpha_{\varpi}^{E, T}(T) \theta \\
D_{\mathrm{m}}=d_{m \varpi}^{\mathrm{T}}(T) \sigma_{\varpi}+\varepsilon_{m k}^{\sigma, T}(T) E_{k}+\mathcal{P}_{\mathrm{m}}^{\sigma, T}(T) \theta,
\end{gathered}
$$

where superscripts $E, T$ and $\sigma$ indicate constant voltage, temperature and stress conditions, and $\varpi$ and $\beta=1, \ldots, 6$ and $k$ and $m=1,2,3$. The other values, $\mathcal{P}, s, S, T, d, E, \alpha, \theta, D$ and $\varepsilon$, represent the pyroelectric constant, elastic compliance tensor, strain, temperature, piezoelectric strain coefficient, electric field, coefficient of thermal expansion, temperature difference, electric displacement and electric permittivity, respectively. Although there have been a great deal of predictive models derived for performance of piezoelectric materials, the majority have been for specific designs and have neglected temperature and nonlinear material responses.

Other coefficients and factors used to describe the properties of piezoelectric materials include coupling coefficient (described in section 3.3), voltage coefficient and mechanical quality factor. In addition to the expression for coupling coefficients found in section 3.3, an expression for a composite piezoelectric material, the effective electromechanical coupling factor, $k_{\text {eff }}$ [254], is expressed as

$$
k_{\mathrm{eff}}=\sqrt{1-\left(\frac{F_{\mathrm{r}}}{F_{\mathrm{a}}}\right)^{2}},
$$

where $F_{\mathrm{r}}$ is the resonance frequency $(\mathrm{Hz})$ and $F_{\mathrm{a}}$ is the antiresonance frequency $(\mathrm{Hz})$ of a piezoelectric cantilever beam. The voltage coefficient, $g\left(\mathrm{~V} \mathrm{~m} \mathrm{~N}^{-1}\right)$ [250, 254] is expressed as

$$
g=\frac{d}{\varepsilon^{\mathrm{T}}}
$$

The mechanical quality factor, $Q_{\mathrm{M}}[250]$, is defined as

$$
Q_{\mathrm{M}}=2 \pi \frac{\text { energy stored } / \text { cycle }}{\text { energy dissipated } / \text { cycle }}
$$

The amount of energy, $E_{\mathrm{C}}$, stored in a piezoelectric element is

$$
E_{\mathrm{C}}=\frac{1}{2} C V^{2}
$$

where $C$ is the capacitance of the piezoelectric source and $V$ is the voltage produced [249].

In addition to the expression for efficiency described in section 3.3, the efficiency of piezoelectric devices can also be computed from two additional expressions [255-257]. Equation (39) provides another expression for efficiency, wherein the ability of the piezoelectric material to convert mechanical energy to electrical energy is expressed as a function of coupling coefficient and mechanical quality factor. This expression [257] is significant because it illustrates that increasing $k$ and $Q_{\mathrm{M}}$ enhances the efficiency of the device, and hence provides a good guideline for material selection. It illustrates that reduction of the structural stiffness can lead to the largest gain in efficiency:

$$
\eta=\frac{\frac{1}{2}\left(\frac{k^{2}}{1-k^{2}}\right)}{\frac{1}{Q_{\mathrm{M}}}+\frac{1}{2}\left(\frac{k^{2}}{1-k^{2}}\right)} .
$$

The other [58] expression for efficiency is based on a piezoelectric cantilever beam subjected to a vibration load:

$$
\begin{aligned}
\eta & =\frac{P_{\text {out }}}{P_{\text {in }}} \times 100 \% \\
& =\frac{1}{M} \sum_{n=2}^{M} \frac{\left(V_{n}+V_{n-1}\right)^{2} / R}{\left[\left(F_{n}+F_{n-1}\right)\left(\delta_{n}-\delta_{n-1}\right)\right] /\left(t_{n-t_{n-1}}\right)} \times 100 \% .
\end{aligned}
$$

In equation (40), $V$ is the voltage drop across the load resistance, $R$ is the load resistance, $F$ is the force applied to the base of the cantilever beam, $\delta$ is the displacement of the beam, $t$ is the time increment between captured data points, $n$ is the data point index and $M$ is the total number of data points measured. 
(a)

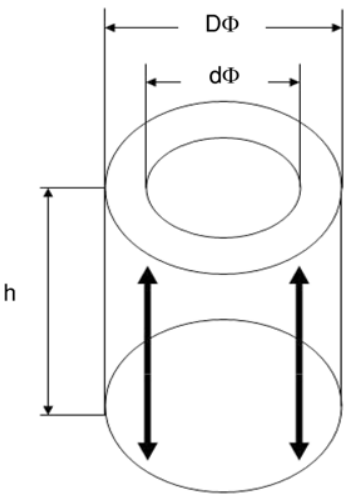

length mode (thin wall tube)

(c)

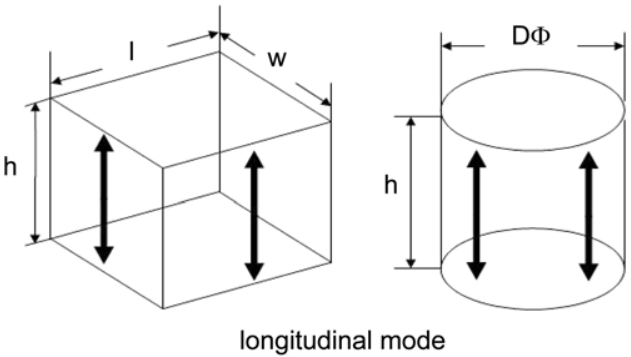

(cylinder or block, h>3.161, w, DФ)

(e)

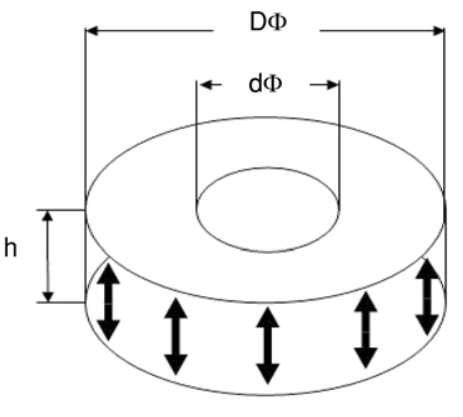

thin disc or plate, $1, \mathrm{w}, \mathrm{D} \Phi>3.16 \mathrm{~h}$

(g)

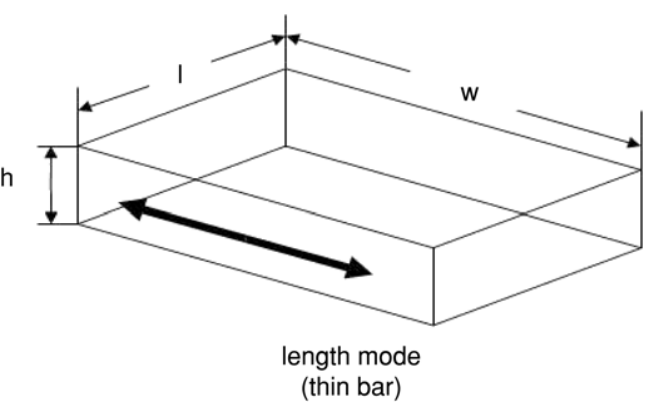

(b)

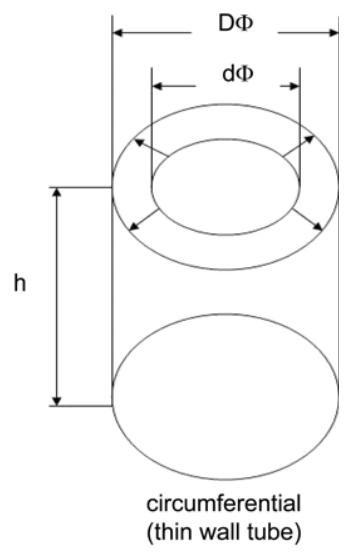

(d)

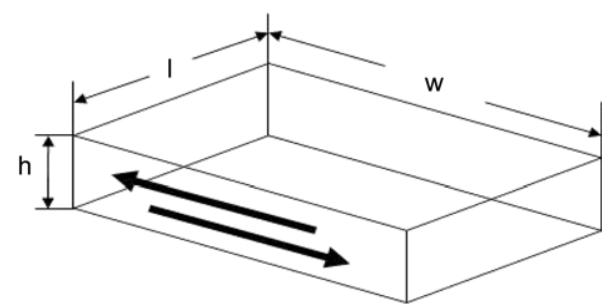

shear mode plate

(f)

h

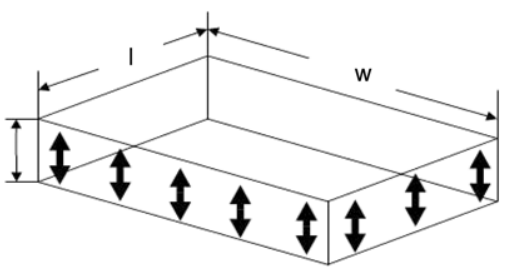

thickness mode

for plate, $\mathrm{I}, \mathrm{w}>3.16 \mathrm{~h}$

for disk $\mathrm{D} \Phi>3.16 \mathrm{~h}(\mathrm{D} \Phi=$ diameter of the disk)

(h)

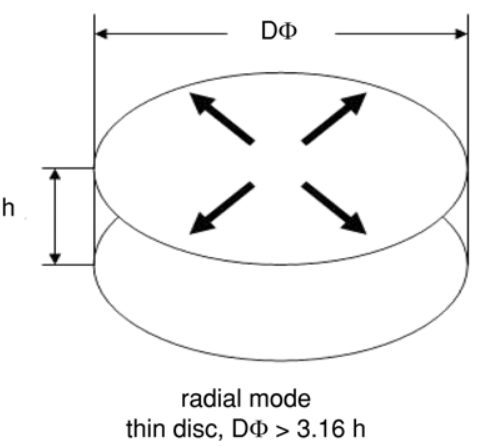

Figure 7. Common modes of vibration.

\subsection{Piezoelectric structures and modes of mechanical loading}

Piezoelectric materials produce an electrical charge when subjected to mechanical loads and/or vibration. The voltage and charge produced depend on the mechanical, electrical and material properties of the piezoelectric, the mechanical loading and the structure of the device used. Modes of vibration are presented in figures 7(a)-(h) [258]. Examples of piezoelectric structures are: unimorphs, bimorphs, multilayered stacks, rainbows, s-morphs, moonie and cymbal. Some of these structures are shown in figures 8(a)-(f) [258]. 
(a)

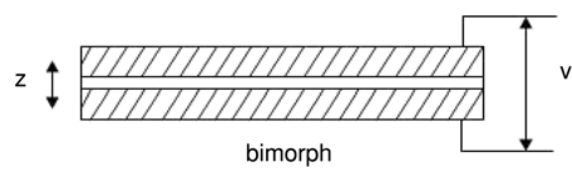

(b)

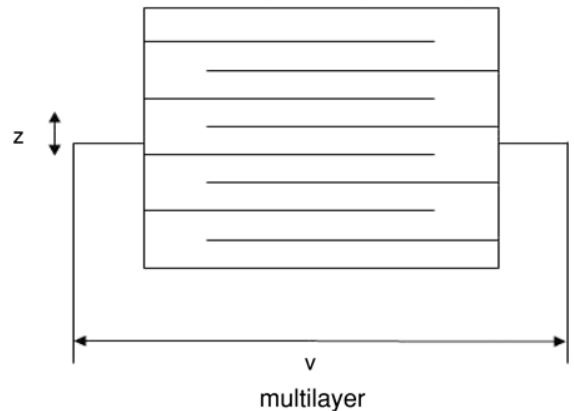

(c)

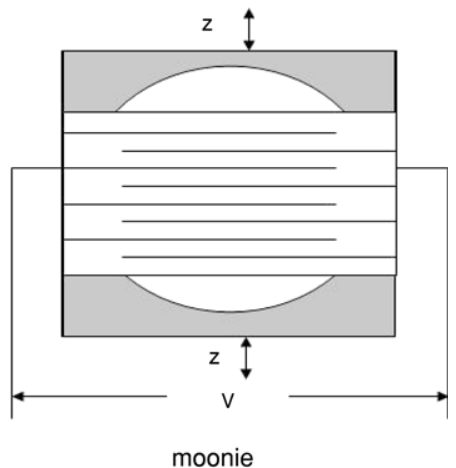

(d)

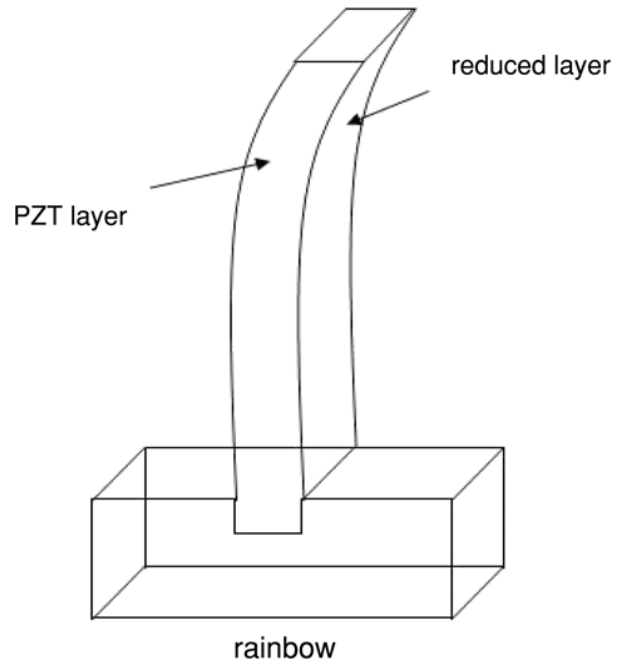

(e)

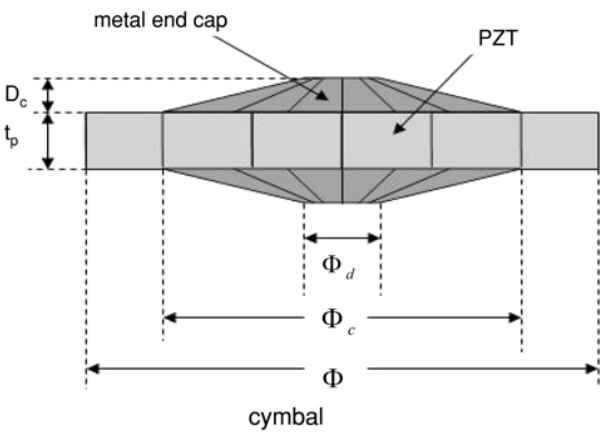

(f)

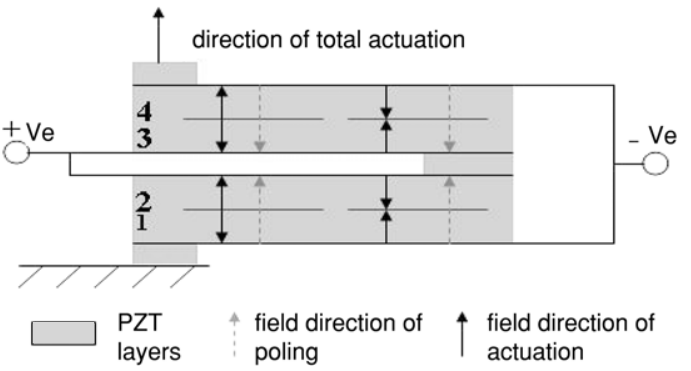

Figure 8. (a) Bimorph piezoelectric structure. (b) Multilayer piezoelectric structure. (c) Moonie piezoelectric structure. (d) RAINBOW piezoelectric structure. (e) Cymbal piezoelectric structure. (f) S-morph piezoelectric structure.

Unimorphs are the building block structure for bimorphs and multi-layer stacks. Unimorphs consist of a piezoelectric material sandwiched between two electrodes. Frequently, a metallic, elastic shim is bonded to one side of the material to improve the structural properties of the device. A bimorph consists of two piezoelectric plates bonded together to form either an antiparallel (series) or parallel-type generator, as shown in figures 9(a) and (b), respectively [258], and multi-layer structures comprise more than two layers of unimorphs. Multilayer piezoelectric structures have enhanced structural rigidity, which often result in longer device life cycles. Moonies consist of a thin multi-layer element and two metal plates with a moon-shaped cavity bonded together [258]. The moonie configuration was developed to produce larger deflections than multi-layered structures and response times for applied voltage that are quicker than bimorphs. Cymbal (dimorph) devices consist of one or more layers of piezoelectric material sandwiched between cymbal-shaped end caps [242, 243, 254]. Reduced and internally biased oxide wafers (RAINBOW actuators) have an electromechanically reduced passive layer on an unreduced piezoelectric layer [259]. S-morphs are accordion-shaped structures developed for optimization of displacement and bending [260]. The s-morph shape is achieved by splitting the central electrode and applying opposite actuation field directions over half of the beam, resulting in a ' $\mathrm{S}$ ' shape rather than the constant curvature of a bimorph beam. The majority of the piezoelectric structures were developed to enhance 


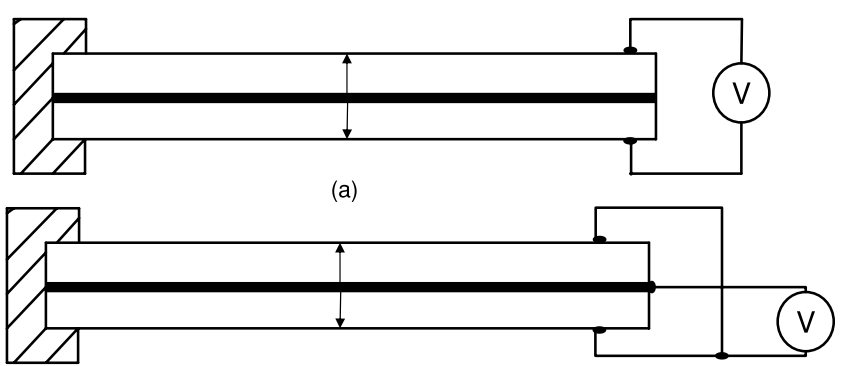

(b)

Figure 9. (a) Antiparallel polarization piezoelectric bimorphs.

(b) Parallel polarization piezoelectric bimorphs.

transducer performance; however, only a few of the structures (bimorphs, dimorphs and moonies) have been used for energy harvesting.

The mounting of piezoelectric generators can vary: however, the most common mounting configuration is a cantilever beam subjected to 33 and 31 loading as illustrated in figures 10(a) and (b) [48], wherein $x, y$, and $z$ are labeled 1, 2 and 3, respectively. In 33-mode, the voltage and stress act in the same direction and in 31-mode the voltage acts in the 3 direction, while the mechanical stress acts in the 1 direction. For structures with a rectangular cross section and surface area, the poling direction is denoted as the ' 3 ' direction, and 33 loading refers to the collection of charge on the electrode surface perpendicular to the polarization direction when tensile or compressive mechanical forces are applied along the polarization axis. When a material experiences ' 31 ' loading, the charge is collected on the electrode surface perpendicular to the polarization direction, when force is applied perpendicular to the axis of polarization. Since the coupling factor of the 33-mode is higher than 31-mode, the 33mode can achieve higher energy conversion. However, for a very low pressure source and limited device size, the 31-mode conversion may be more suitable for energy harvesting, since larger strains can be produced with smaller input forces with 31 loading.

\subsection{State-of-the-art in energy harvesting using piezoelectric materials}

The piezoelectric effect is expressed in materials such as single crystals, ceramics, polymers, composites, thin films and relaxor-type ferroelectric materials. Of the existing piezoelectric materials, polymers and ceramics [242, 243, 251, 261] have been most widely explored as energy harvesting materials. This section describes the state-of-the-art in piezoelectric materials development for energy harvesting and transducer applications.

Single-crystal piezoelectric materials include quartz, lithium niobate $\left(\mathrm{LiNbO}_{3}\right)$ and lithium tantalate $\left(\mathrm{LiTaO}_{3}\right)$, and are currently used for frequency stabilized oscillators and surface acoustic devices. Single-crystal materials are isotropic, e.g. have different material properties depending on the cut of the material and direction of bulk or surface wave propagation $[222,258]$, and have high electromechanical coupling coefficients for surface acoustic waves. Although

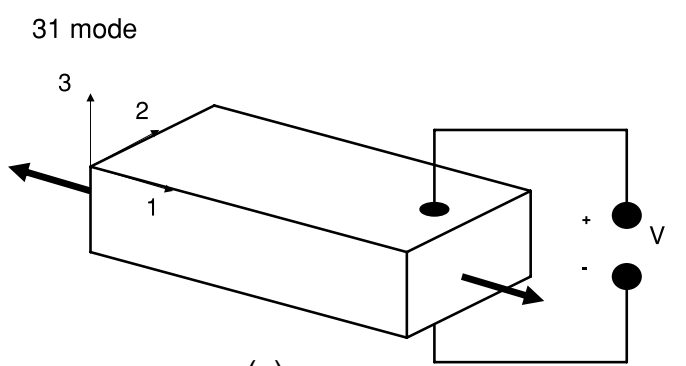

(a)

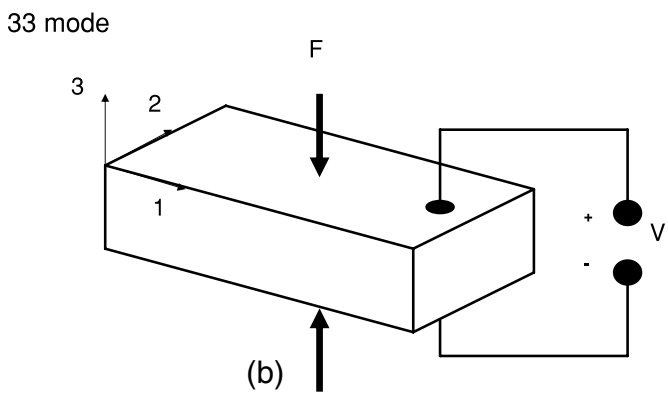

Figure 10. (a) 31-mode of loading for piezoelectric structures. (b) 33-mode of loading for piezoelectric structures.

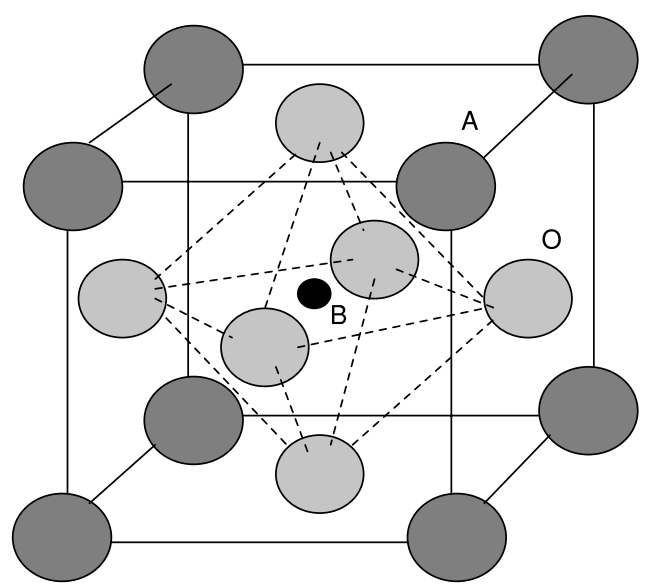

Figure 11. Perovskite structure common in most ceramic piezoelectric materials.

these types of materials have been investigated for oscillator and acoustic devices, investigation of these materials for energy harvesting is limited. In one study [262] the efficiency of lithium niobate $\left(\mathrm{LiNbO}_{3}\right)$ was compared to the piezoelectric ceramic, PZT, where plates were subjected to hammer impact. The electricity generated per impact for $\mathrm{LiNbO}_{3}$ was smaller than PZT, because the dielectric constant of $\mathrm{LiNbO}_{3}$ was smaller than for the commercial PZT studied. However, the piezoelectric efficiency of $\mathrm{LiNbO}_{3}(78 \%)$ was greater than the commercially manufactured PZT $(68 \%)$ studied.

Ceramic piezoelectric materials include barium titanate $\left(\mathrm{BaTiO}_{3}\right)$, lead zirconate-lead titanate $\left(\mathrm{PbZr}_{x} \mathrm{Ti}_{1-x} \mathrm{O}_{3}\right)-\mathrm{PZT}$ and lead titanate $\left(\mathrm{PbTiO}_{3}, \mathrm{PCT}\right)$. Most piezoelectric ceramics have a perovskite structure $\mathrm{ABO}_{3}$ (figure 11 [222]), consisting of a simple cubic structure with a large cation, A, 

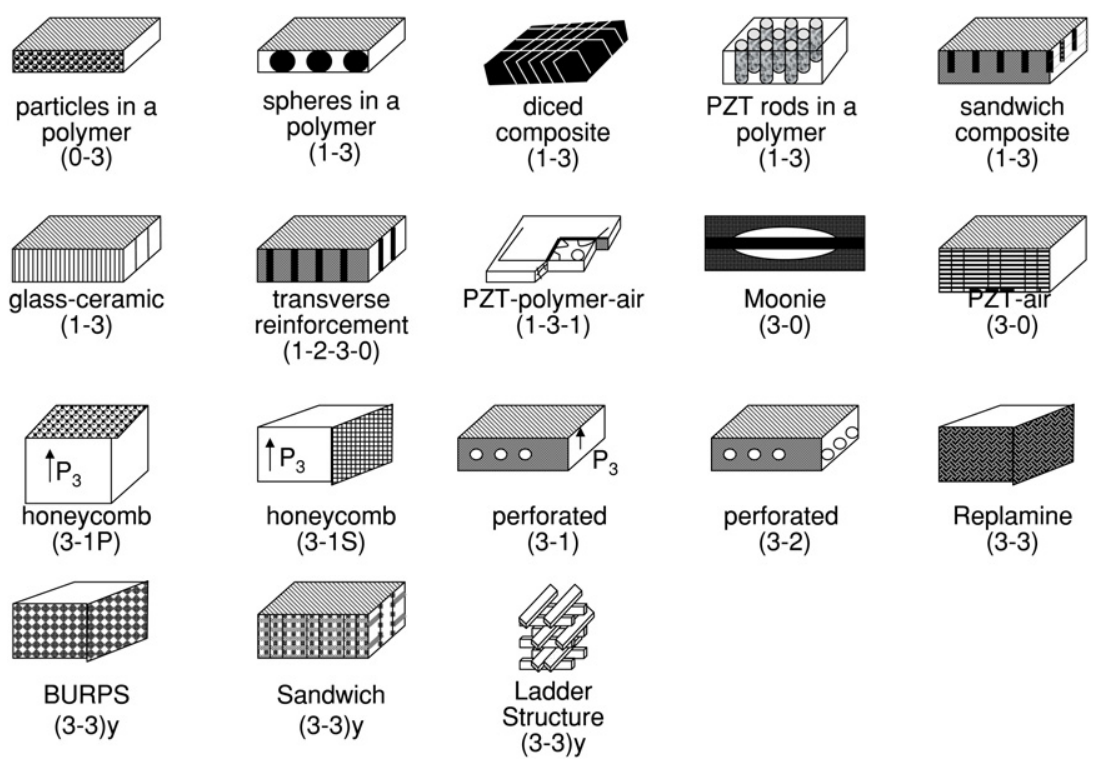

Figure 12. Schematics of typical piezoelectric ceramic composite structures.

on the corner, a smaller cation, $\mathrm{B}$, in the body center and oxygen, $\mathrm{O}$, in the centers of the faces [222]. These materials have been extensively studied for energy harvesting because perovskite materials can be easily tailored for various applications by incorporating different types of cations within the structure. The dielectric and piezoelectric constants of barium titanate are a function of temperature, stoichiometry, microstructure and doping. Examples of dopants used for $\mathrm{BaTiO}_{3}$ materials are lead $(\mathrm{Pb})$ or calcium $(\mathrm{Ca})$, which enter $\mathrm{A}$ or $\mathrm{B}$ sites. As opposed to $\mathrm{BaTiO}_{3}$, the piezoelectric constants for PZT are not strongly dependent upon temperature, but rather on material composition. Doping of these materials with donors or acceptors produces dramatic material property changes. Common doping ions used are $\mathrm{Nb}^{5+}$ and $\mathrm{Ta}^{5+}$, which when used in $\mathrm{PbZr}_{x} \mathrm{Ti}_{1-x} \mathrm{O}_{3}$ result in soft materials such as PZT-5. One study examined the influence of doping PZT with $\mathrm{Mn}\left(\mathrm{Pb}_{0.99} \mathrm{Mn}_{0.01}\right)\left(\mathrm{Zr}_{0.52} \mathrm{Ti}_{0.48}\right) \mathrm{O}_{3}$ [263]. In this study, samples were subjected to compression from drop-weight impact tests. The results from these experiments indicated that the voltage released from the slowly applied stress (compression) was of the same order of magnitude as the impact stress tests, but the energy released from the impact stress was lower than the slowly applied stress. These tests rendered a 10-6 conversion ratio of energy for the impact stress case and 10-2 for the slowly applied stress case. Others [264] have investigated the influence of doping parameters in PZT materials. In one study PZT was doped with Mn: $\mathrm{Pb}\left[\left(\mathrm{Zr}_{0.52} \mathrm{Ti}_{0.48}\right) \mathrm{O}_{3}\right]_{1-x}\left[\left(\mathrm{Zn}_{1 / 3} \mathrm{Nb}_{2 / 3}\right) \mathrm{O}_{3}\right]_{x+y} \mathrm{MnCO}_{3}$, where $x=$ 0.1 and $y$ was varied from 0.5 to 0.9 per cent weight. In these studies, a figure of merit, $d \cdot g$ product was computed for comparison of piezoelectric materials for energy harvesting applications. The product $d \cdot g$, was optimized from the maximization of the expression

$$
|d|=\varepsilon^{v},
$$

where $\varepsilon$ was the permittivity of the material and $v$ was obtained from empirical data. In equation (41), practical values of $v$ were in the range of 1.1-1.3. This same study also included the development of a two-step sintering process to optimize polycrystalline ceramic composition with low magnitudes of $v$.

The fabrication of lead titanate materials with lanthanum and calcium has been demonstrated via soft solution processing [233], sol-gel spin coating [226] and traditional dry ceramic techniques [265]. Samarium-modified PCT was investigated for application to infrared sensors, electrooptic devices and ferroelectric memory devices. In one study [266, 267] samarium-modified PCT with composition $\left(\mathrm{Pb}_{0.76-x} \mathrm{Sm}_{x} \mathrm{Ca}_{0.24}\right)\left(\mathrm{Ti}_{0.98} \mathrm{Mn}_{0.02}\right) \mathrm{O}_{3}$ was prepared where $x$ was varied from 0 to 0.08 . Increasing Sm concentration increased the dielectric constant, due to the reduced tetragonality of the structure and denser structure from the Sm substitution. Polycrystalline samples of lanthanum-modified PCT ceramics [265] with composition $\mathrm{Pb}_{0.76-3 x / 2} \mathrm{La}_{x} \mathrm{Ca}_{0.24} \mathrm{Mn}_{0.02} \mathrm{Ti}_{0.98} \mathrm{O}_{3}$ were fabricated with $x=0-0.08$ using a conventional dry ceramic processing technique. The dielectric constant of these materials at room temperature increased with elevated amounts of lanthanum.

Polymer piezoelectric materials such as polyvinylidene difluoride (PVDF) or $\mathrm{PVF}_{2}$ demonstrate the piezoelectric effect when they are stretched or formed during fabrication. The copolymerization of vinylidene difluoride with trifluroethylene (TrFE) produces a copolymer called PVDF-TrFE, which does not need to be stretched to induce piezoelectric behavior.

Composite piezoelectric materials comprise a piezoelectric ceramic and a polymer. Piezoelectric composites are defined [268] based on their connectivity between phases. When only two materials are used, e.g. two phases (diphasic), there are ten possible connectivities: $0-0,1-0,2-0,3-0,1-1,2-$ $1,3-1,2-2,3-2$ and 3-3. Several composite structures that represent some of these connectivities are shown in figure 12 [269]. Many of these structures have yet to be realized, while the majority of composite piezoelectric work has been limited 
to PZT rod and fibrous composites. The influence of diameter size on performance [270] of fibrous PZT composites with diameters of $15,45,120$ and $250 \mu \mathrm{m}$, respectively (1-3 composite form), produced the maximum voltage achieved of $350 \mathrm{~V}$ with a corresponding output power of $120 \mathrm{~mW}$. 1-3 piezoelectric composites comprised of PZT rods embedded within a polymer matrix are predicted to be one of the most promising structures for transducer and acoustic applications, because of high coupling factors, low acoustic impedance, mechanical flexibility and broad bandwidth coupled with low mechanical quality factor. The high coupling factors also make them ideal candidates for energy harvesting devices.

Relaxor-type ferroelectrics differ from traditional ferroelectric materials because they have a broad phase transition from paraelectric to ferroelectric state, dielectric relaxation and weak remnant polarization. The dielectric maximum and amplitude of dielectric permittivity of these materials depend on both frequency and temperature [271]. Several relaxor-type ferroelectric materials have been investigated for transducer applications: single crystals of $\mathrm{Pb}\left(\mathrm{Mg}_{1 / 3} \mathrm{Nb}_{2 / 3}\right) \mathrm{O}_{3}$ $(\mathrm{PMN}), \mathrm{Pb}\left(\mathrm{Zn}_{1 / 3} \mathrm{Nb}_{2 / 3}\right) \mathrm{O}_{3}(\mathrm{PZN})$ and binary systems of these systems coupled with $\mathrm{PbTiO}_{3}$, PMN-PT and PZN-PT. These materials are under investigation because of their large coupling coefficients, large piezoelectric constants and high strain levels, which are higher than many piezoelectric ceramic materials [272]. PMN-PT single crystals have high longitudinal electromechanical coupling factors that are $90 \%$ greater than PZT [273]. PMN, PZN, PMN-PT and PZN-PT are currently under investigation for transducer technology. However, there has been little investigation of these materials as energy harvesters.

Nanowire zinc oxide arrays have been grown on a singlecrystal sapphire substrate [274]. The nanowires were aligned and activated via contact from a conductive atomic force microscopy tip. The bending of the nanowires resulted in a strain field and charge separation across the nanowires. Also, the Schottky barrier formed between the AFM tip and nanowire resulted in current flow. In this study, the nanowire diameters and lengths were $300 \mathrm{~nm}$ and $1 \mu \mathrm{m}$, respectively, and individual wires produced output power of $5 \mathrm{pW}$ at $45 \mathrm{mV}$.

\subsection{Proof-of-concept devices and fabrication techniques}

Proof-of-concept prototypes and fabrication techniques have been explored for piezoelectric energy harvesting. Table 12 $[19,181,182,186,230,248,249,251,254,275,276]$ details novel piezoelectric devices, their application and power, voltage and current data.

Thin- and thick-film piezoelectric material fabrication techniques such as photomask [230], screen print [182], sol-gel [277] and photolithography [19, 277] have been demonstrated for PZT, PZN-PT and PMN-PT structures for energy harvesting. In addition to these MEMS devices, macroscaled energy harvesting proof-of-concept devices have also been fabricated.

Windmills. Three types of windmill designs have been [245, 248, 275] constructed. The first design consisted of $\mathrm{PVF}_{2}$ bimorphs subjected to 33 compressive loading from rotation and mechanical oscillation from the wind. It was concluded from this study that for compressive 33-mode loading, higher oscillating frequencies were necessary, and one means of achieving this was to scale down the oscillator size and increase the number of oscillating devices. The second piezoelectric windmill design comprised of twelve PVDF piezoelectric bimorphs positioned along the circumference of the mill with cantilever supports. In this design, wind flow induced a camshaft gear mechanism to oscillate, thereby causing the bimorphs to deflect, resulting in electrical power. The third windmill design was created for small-scale applications. The structure was made primarily of plastic and comprised 18 bimorphs. This windmill when subjected to an average wind speed of 10 miles $^{-1}$ produced $5 \mathrm{~mW}$ of continuous power.

Shoe inserts. Several workers have investigated energy harvesting from piezoelectric shoe inserts. One design comprised two shoe inserts [249] subjected to 31-mode loading, wherein one insert was a flexible PVDF bimorph mounted under the insole of the shoe, while the other was a dimorph structure consisting of a curved semi-flexible PZT material laminated onto pre-stressed metal strips, subjected to heel pressure. The authors concluded that, since the low frequency piezoelectric sources were capacitive, they produced high voltage, low energy and low current pulses (10-7 A), which were an efficient means of conversion of mechanical to electrical energy, as long as adequate power conditioning was provided. The second shoe insert design [278] was also made of a PVDF bimorph subjected to 31-mode loading conditions. These workers concluded that piezoelectric rectangular beams subjected to 31-mode loading conditions required high length to height ratios in order to produce maximum charge density. A third shoe insert design [261] comprised a two-layer curved unimorph shoe insert. This design was modeled using shallow thin shell theory and linear piezoelectric constitutive equations, and was used to identify the influence of thickness, length, width and center height on maximum charge density. These workers found that the dimensions of the unimorph influenced its overall power production. Specifically, they found that increasing the width of the unimorph resulted in higher charge generation than increasing the length. Second, they concluded that increasing the center height and thickness of the substrate (limited by available input force) also enhanced charge generation of the generator.

Other workers have investigated the influence of geometrical modification on device performance. For example, one group fabricated clamped short discs for piezoelectric energy harvesting [242, 243] and concluded that the ratio of layer thickness (piezoelectric layer to substrate layer) and electrode pattern significantly influences the energy harvested from the piezoelectric device.

Implantable devices. Several groups have investigated piezoelectric energy harvesting from implantable devices. In one study [181], PZT-5A, PZT-5H and PVDF membranes were used to produce power from fluctuating blood pressure. Although the devices did produce power, the amount of power produced was insufficient for the proposed application. The workers concluded that further development of materials, signal processing and device design were required for the 
Table 12. Description of novel piezoelectric energy harvesting devices, along with power and energy capabilities.

\begin{tabular}{|c|c|c|c|c|c|c|}
\hline Material & Application & Dimensions & Power & $\begin{array}{l}\text { Energy/power } \\
\text { density }\end{array}$ & Voltage & Load \\
\hline $\begin{array}{l}\text { PZT composite-d } 33 \\
\text { compressive loading of } \\
39 \mathrm{MPa}\end{array}$ & Composite & - & - & $12 \mathrm{~mW} \mathrm{~cm}^{-3}$ & - & - \\
\hline $\begin{array}{l}\text { PVF2, d33 compressive } \\
\text { load }\end{array}$ & $\begin{array}{l}\text { Wind mill rotor } \\
\text { design }\end{array}$ & $\begin{array}{l}500 \mu \mathrm{m} \times \\
90 \mathrm{~mm} \times 70 \mathrm{~mm}\end{array}$ & $2.4 \mu \mathrm{W}$ & $0.76 \mu \mathrm{W} \mathrm{cm}^{-3}$ & $1 \mathrm{~V}$ & $400 \mathrm{k} \Omega$ \\
\hline PVDF bimorph, d31-mode & Shoe insert & - & $1.3 \mathrm{~mW}$ & - & $18 \mathrm{~V}$ & $250 \mathrm{k} \Omega$ \\
\hline PZT dimorph, d31-mode & Shoe insert & - & $8.4 \mathrm{~mW}$ & - & $64.8 \mathrm{~V}$ & $500 \mathrm{k} \Omega$ \\
\hline $\begin{array}{l}\text { PVDF bimorph windmill, } \\
12 \text { cantilever bimorphs } \\
\text { d31 loading }\end{array}$ & Windmill & $\begin{array}{l}\text { Each bimorph: } \\
60 \times 20 \times 0.5 \mathrm{~mm}^{3}\end{array}$ & $10.2 \mathrm{~mW}$ & $1.42 \mathrm{~mW} \mathrm{~cm}^{-3}$ & $6.8 \mathrm{~V}$ & $4.6 \mathrm{k} \Omega$ \\
\hline $\begin{array}{l}\text { PZT-5A membrane, } \\
\text { d31 loading from blood } \\
\text { pressure }\end{array}$ & Biomedical & $\begin{array}{l}\text { Surface area }=1 \mathrm{~cm}^{2} \\
\text { Thickness }=9 \mu \mathrm{m}\end{array}$ & $2.3 \mu \mathrm{W}$ & $2.6 \mathrm{~mW} \mathrm{~cm}^{-3}$ & - & - \\
\hline $\begin{array}{l}\text { PZT rectangular structure, } \\
\text { knee implant, } \\
\text { d33 compressive loading }\end{array}$ & Knee implant & $1.0 \times 1.0 \times 1.8 \mathrm{~cm}^{3}$ & $4.8 \mathrm{~mW}$ & $0.89 \mathrm{~mW} \mathrm{~cm}^{-3}$ & - & - \\
\hline $\begin{array}{l}\text { PZT thin-film membrane } \\
\text { generator } \\
\text { coupled with heat engine }\end{array}$ & Hybrid & $\begin{array}{l}\text { Surface area }=3 \mathrm{~mm}^{2} \\
\text { Thickness }=3.4 \mu \mathrm{m}\end{array}$ & $56 \mu \mathrm{W}$ & $5.5 \mathrm{~W} \mathrm{~cm}^{-3}$ & - & - \\
\hline $\begin{array}{l}\text { PZT cymbal device, } \\
\text { d33 loading }\end{array}$ & Cymbal & $\begin{array}{l}\text { Diameter }=29 \mathrm{~mm} \\
\text { Thickness }=1 \mathrm{~mm}\end{array}$ & $29 \mathrm{~mW}$ & $43.9 \mathrm{~mW} \mathrm{~cm}^{-3}$ & - & - \\
\hline $\begin{array}{l}\text { PZT projectile generator, } \\
\text { d33 compressive loading }\end{array}$ & Pulse generator & $\begin{array}{l}\text { Diameter }=1.27 \mathrm{~cm} \\
\text { Thickness }=0.13 \mathrm{~cm}\end{array}$ & $25 \mathrm{~kW}$ & $151.4 \mathrm{~kW} \mathrm{~cm}^{-3}$ & $500 \mathrm{~V}$ & $10 \Omega$ \\
\hline $\begin{array}{l}\text { PMN-PT composite-d33 } \\
\text { compressive loading of } \\
40.4 \mathrm{MPa}\end{array}$ & Composite & - & - & $22.1 \mathrm{~mW} \mathrm{~cm}^{-3}$ & - & - \\
\hline Material & Dimensions & Power & Application & $\begin{array}{l}\text { Energy/power } \\
\text { density }\end{array}$ & Voltage & Resistance \\
\hline $\begin{array}{l}\text { Unimorph membrane } \\
\text { transducer subjected to } \\
\text { shaker vibration }\end{array}$ & $\begin{array}{l}\text { Total radius }=20.5 \mathrm{~mm}, \\
\text { PZT radius }=12.5 \mathrm{~mm}, \\
\text { PZT thickness }=230 \mu \mathrm{m}, \\
\text { bras thickness }=400 \mu \mathrm{m}\end{array}$ & $1.7 \mathrm{~mW}$ & $\begin{array}{l}\text { Low power } \\
\text { sensors }\end{array}$ & $0.106 \mathrm{~mW} \mathrm{~cm}^{-3}$ & $9 \mathrm{~V}$ & $47 \mathrm{k} \Omega$ \\
\hline $\begin{array}{l}\text { PZT thin-film d33-mode } \\
\text { cantilever generator }\end{array}$ & $170 \mu \mathrm{m} \times 260 \mu \mathrm{m}$ & $1 \mu \mathrm{W}$ & MEMS & $0.74 \mathrm{mWh} \mathrm{cm}^{-2}$ & $2.2 \mathrm{~V}$ & $5.2 \mathrm{M} \Omega$ \\
\hline $\begin{array}{l}\text { PZT thick-film operating } \\
\text { at } 80 \mathrm{~Hz}\end{array}$ & $20 \mu \mathrm{m}$ thick layers & $2 \mu \mathrm{W}$ & MEMS & - & $0.816 \mathrm{~V}$ & $333 \mathrm{k} \Omega$ \\
\hline $\begin{array}{l}\text { PZT with } 1.5 \mathrm{MPa} \text { lateral } \\
\text { stress operating at } 15 \mathrm{~Hz}\end{array}$ & Volume $=0.2 \mathrm{~cm}^{3}$ & $1.2 \mathrm{~mW}$ & $\begin{array}{l}\text { Autonomous } \\
\text { wireless } \\
\text { transmitter }\end{array}$ & $6 \mathrm{~mW} \mathrm{~cm}^{-3}$ & $9 \mathrm{~V}$ & - \\
\hline $\begin{array}{l}\text { PZT stacked } \\
\text { generator-164 layers } \\
\text { at } 1 \mathrm{~Hz} \text { subjected to } 250 \mathrm{~N}\end{array}$ & $5 \mathrm{~mm} \times 5 \mathrm{~mm} \times 8 \mathrm{~cm}$ & $690 \mu \mathrm{W}$ & $\begin{array}{l}\text { Power from } \\
\text { activated muscle }\end{array}$ & $345 \mu \mathrm{W} \mathrm{cm}{ }^{-3}$ & $19.3 \mathrm{~V}$ & $540 \mathrm{k} \Omega$ \\
\hline $\begin{array}{l}\text { PZT, steel and brass drum } \\
\text { actuator subjected to } \\
\text { cyclic stress of } 0.7 \mathrm{~N} \text { at } \\
590 \mathrm{~Hz}\end{array}$ & Volume $=0.51 \mathrm{~cm}^{3}$ & $11 \mathrm{~mW}$ & - & $21.57 \mathrm{~mW} \mathrm{~cm}^{-3}$ & 14.07 & $18 \mathrm{k} \Omega$ \\
\hline $\begin{array}{l}\text { Nanowire arrays of } \\
\text { piezoelectric and } \\
\text { semiconductive } \mathrm{ZnO}\end{array}$ & $\begin{array}{l}300 \mathrm{~nm} \text { diameter wire } \\
\text { Array dimensions: } \\
6.5 \mu \mathrm{m} \times 3.2 \mu \mathrm{m}\end{array}$ & $\sim 10-20 \mathrm{pW} /$ wire & $\begin{array}{l}\text { Biosensors and } \\
\text { self-powered } \\
\text { electronics }\end{array}$ & $0.1-0.2 \mathrm{~mW} \mathrm{~cm}^{-2}$ & $20 \mathrm{mV}$ & \\
\hline
\end{tabular}

realization of devices for adequate power production. A 33mode PZT generator prototype for powering an orthopedic knee implant [246, 251] was fabricated for implantation within a total knee replacement implant. Although the actual device was not implanted, it was subjected to lifetime studies. The results indicated a linear decrease in power per decade of operational time. A comparison of stacked versus monolithic elements of PZT was also investigated in this study and it was concluded that elements with the same geometry produced the same output power, with matching loads. However, the stacked elements required lower matching electrical load requirements, resulting in lower output voltages, which were more manageable in real world applications.

Wave energy. Devices, called Eels, have been fabricated to harvest energy from water movement [279, 280]. These devices were comprised of PVDF beams that were placed in the wake of a bluff body in oceans and rivers. Preliminary studies indicate that larger scaled devices would produce power in the milliwatt and watt power ranges.

Pulse generators. Pulse generators [186, 188] are piezoelectric materials that are subjected to a high impact force or projected at a high speed onto a rigid surface (33-mode 


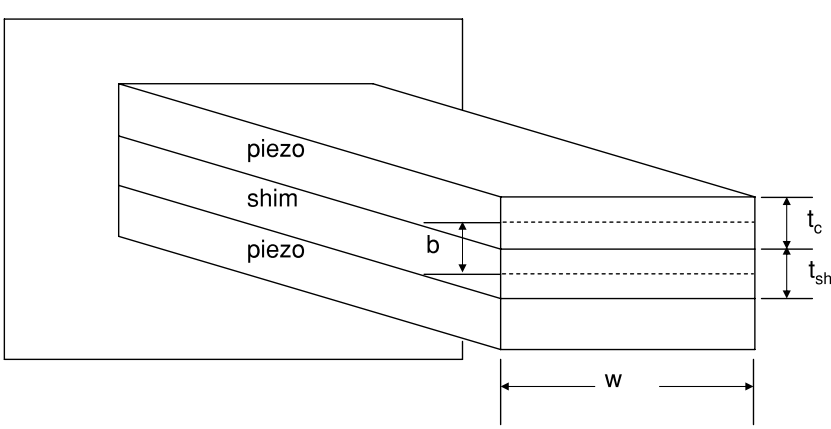

Figure 13. Typical cantilever generator.

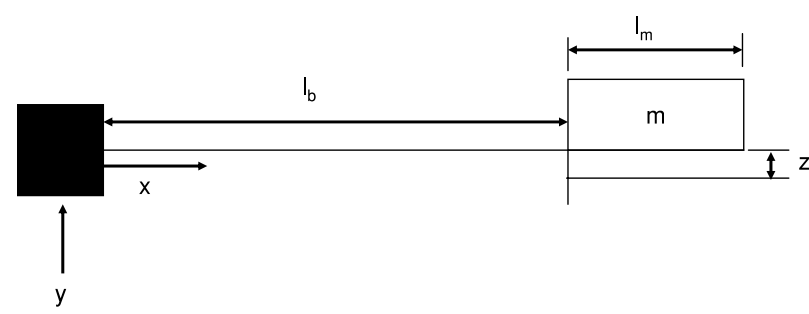

Figure 14. Side view of cantilever structure that included mass.

loading). Although these devices produced relatively large power compared to 31-mode load devices, applications for such devices are still unclear.

\subsection{Predictive models of piezoelectric devices_circuit models}

Several numerical models to describe the behavior of specific piezoelectric devices have been developed. Piezoelectric generators are typically modeled as circuit elements $[47,48,55,196]$. The models in this section apply to generators that are poled along the 3 -axis with electrodes placed perpendicular to the 3 -axis (figures 13 and 14). Driving vibrations are assumed to exist only along the 3 -axis, and the piezoelectric material is assumed to have a one-dimensional state of stress along the 1-axis. Given these assumptions, the constitutive equations for strain and electrical displacement reduce to the following:

$$
S_{1}=s_{11}^{\mathrm{E}} T_{1}+d_{31} E_{3}
$$

and

$$
D_{3}=d_{31} T_{1}+\varepsilon_{3}^{\mathrm{T}} E_{3}
$$

respectively.

4.5.1. Simple model of cantilever bimorph-no resistive load [55]. The electrical circuit for a bimorph cantilever system with no resistive load is depicted in figure 15 [55]. The equivalent circuit for this model includes an equivalent inductor, $L_{\mathrm{m}}$, resistor, $R_{\mathrm{b}}$, capacitor, $C_{k}$, and stress, $\sigma_{\text {in }}$. The equivalent inductor is the mass or inertia of the generator, the equivalent resistor represents the mechanical damping, the equivalent capacitor is the mechanical stiffness and the equivalent stress is the stress resulting from input vibration. $C_{\mathrm{b}}$ is the capacitance of the bender, $n^{\prime}$ is the equivalent turns

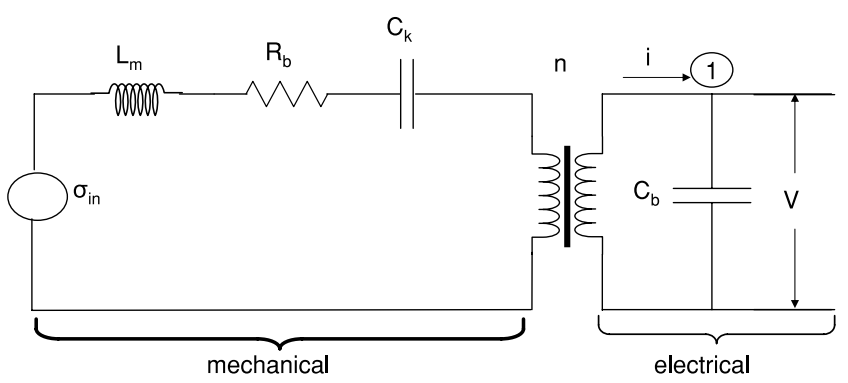

Figure 15. Simple model of cantilever bimorph with no resistive load.

ratio of the transformer, e.g. the piezoelectric coupling, and $V$ is the voltage across the piezoelectric device. In this model, the mechanical side is uncoupled, meaning the stress is $\sigma$, and not $T$, which is induced by mechanical and electrical effects. The system of equations derived in this model are determined using Kirchhoff's voltage and current laws. Specifically, summing the voltage around the mechanical side of the circuit in figure 15 results in the expression

$$
\sigma_{=} L_{\mathrm{m}} \ddot{S}+R_{\mathrm{b}} \dot{S}+\frac{S}{C_{k}}+n^{\prime} V
$$

where

$$
n^{\prime}=\frac{-a d_{31} C_{\mathrm{p}}}{2 t_{\mathrm{c}}}
$$

Summing the current at node 1 (circled in figure 15) yields the following expression for current:

$$
i=C_{\mathrm{b}} \dot{V} .
$$

Equations (44)-(46) coupled with equations (42) and (43) are used to derive a system of equations that are a function of state variables $S, \dot{S}$ and $V$ in [55]. The resulting system of equations in terms of state variables are

$$
\ddot{S}=\frac{-C_{\mathrm{p}}}{k_{1} k_{2}} S-\frac{b_{\mathrm{m}}}{m} \dot{S}+\frac{C_{\mathrm{p}}}{k_{1} k_{2}} \frac{d_{31} a}{2 t_{\mathrm{c}}} V+\frac{\ddot{y}}{k_{2}}
$$

and

$$
\dot{V}=\frac{2 t_{\mathrm{c}} d_{31} C_{\mathrm{p}}}{a \varepsilon} \dot{S},
$$

where $c_{\mathrm{p}}$ is the elastic constant for the piezoelectric material and $b_{\mathrm{m}}$ is the mechanical damping. In equations (45), (47) and (48), $a$ is equal to 1 when the two layers of the device are wired in series and equal to 2 when the layers are wired in parallel. Also, in equations (47) and (48), $m$ is the seismic mass located at the free end of the cantilever structure, $d_{31}$ is the piezoelectric constant and $\varepsilon$ is the dielectric constant in the 3 direction. Also

$$
k_{1}=\frac{b\left(2 l_{\mathrm{b}}+l_{\mathrm{m}}-l_{\mathrm{c}}\right)}{2 I},
$$

and

$$
k_{2}=\frac{l_{\mathrm{b}}^{2}}{3 b} \frac{\left(2 l_{\mathrm{b}}+\frac{3}{2} l_{\mathrm{m}}\right)}{\left(2 l_{\mathrm{b}}+l_{\mathrm{m}}-l_{\mathrm{c}}\right)},
$$

where $l_{\mathrm{c}}$ is the length of the electrode covering the piezoelectric material, $l_{\mathrm{b}}$ is the length of the piezoelectric element not 


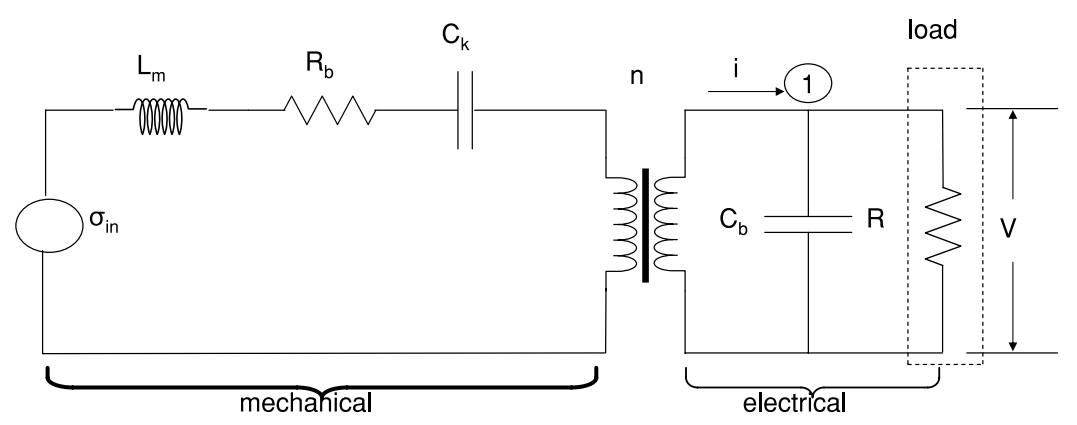

Figure 16. Model of cantilever bimorph with resistive load.

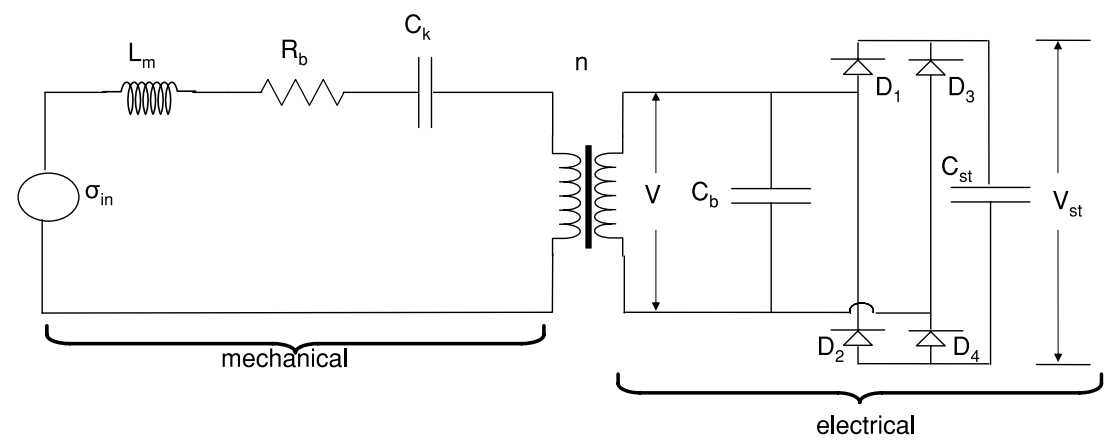

Figure 17. Model of cantilever bimorph with capacitive load.

covered by the seismic mass and $l_{\mathrm{m}}$ is the length of the mass at the free end of the bimorph. Also, in equations (49) and (50) $I$ is the effective moment of inertia, where $\eta_{\mathrm{s}}=C_{\mathrm{sh}} / C_{\mathrm{p}}$, and $C_{\mathrm{p}}$ and $C_{\text {sh }}$ are the elastic constants for the piezoelectric material and center shim of the bimorph, respectively. $I$ is given by

$$
I=2\left[\frac{w t_{\mathrm{c}}^{3}}{12}+w t_{\mathrm{p}} b^{2}\right]+\frac{\eta_{\mathrm{s}} w t_{\mathrm{sh}}^{3}}{12} .
$$

In equation (51) $t_{\mathrm{c}}$ is the thickness of the piezoelectric material, $t_{\mathrm{sh}}$ is the thickness of the shim material and $w$ is the width of the beam. In these expressions, $k_{1}$ is a geometric constant relating the average stress in the piezoelectric material to force exerted by the mass on the end of the beam.

The assumptions used in developing this model were (1) the mass on the end of the beam acts as a point load located at the center of mass, (2) the moment due to rotational inertia of the proof mass was neglected, which is insignificant for the fundamental vibration mode, and (3) the mass of the beam was neglected, which is assumed to have minimal influence on the result since the size of the actuators under investigation are relatively small. This model does not include a resistive or capacitive load and thus acts as a building block for the next two models describes in sections 4.5.2 and 4.5.3. Since this model does not include a resistive or capacitive load, power derived from the system cannot be calculated.

4.5.2. Model of cantilever bimorph with resistive load. This model was informed by the first model described above (section 4.5.1), where no electrical load is applied, e.g. no power is transferred. This model incorporates a resistive load and thus allows for the calculation of power delivered to an electrical load. A circuit representation of this model is provided in figure 16. In this model, the mechanical side of the equivalent circuit remains unchanged, and thus the expression for $\ddot{S}$, in equation (47), remains the same, along with equation (44). However, the currents at node 1 do change due to the addition of the resistive load. Therefore the expression for current in this model becomes

$$
i=C_{\mathrm{b}} \dot{V}+\frac{V}{R}
$$

Hence, the expression for $\dot{V}$ now becomes

$$
\dot{V}=\frac{2 t_{\mathrm{c}} d_{31} c_{\mathrm{p}}}{a \varepsilon} \dot{S}-\frac{1}{R C_{\mathrm{b}}} V .
$$

4.5.3. Model of cantilever bimorph with capacitive load. The model described above in section 4.5.2 is based on a simple resistive load, but is not the best approximation for an actual electrical load [55]. Instead, the equivalent circuit presented in figure 17 is a more realistic depiction of an operational system, wherein $C_{\text {st }}$ refers to a storage capacitor, which could certainly be replaced with a battery. This simplified capacitive load model is typical of many wireless sensor systems. An example of this would be a wireless sensor system where typical duty cycles are about $1 \%$ of the time, while the remaining time is for charging. Figure 17 depicts a system where the vibration converter is allowed to charge a storage capacitor for the majority of the time ( $\sim 99 \%$ of the time). In figure 17 , three different states of operation are presented: (1) diodes $D_{1}$ and $D_{4}$ are conducting, (2) diodes $D_{2}$ and $D_{3}$ are conducting and 
(3) none of the diodes are conducting. Since the mechanical portion of the equivalent circuit does not change in any of the three models presented in this section, the first system equation, equation (47) for $\ddot{S}$, remains the same, and when no diodes are conducting, state 3 , the circuit is identical to the first model presented in section 4.5.1, which has neither a resistive or capacitive load. Hence for state 3, the second system equation, equation (48), remains the same and the voltage, $V_{\text {st }}$, remains constant. For states 1 and $2, \dot{V}$ can be expressed as

$$
\dot{V}=\frac{a c_{\mathrm{p}} d_{31} l_{\mathrm{e}} w}{C_{\mathrm{b}}+C_{\mathrm{st}}} \dot{S} .
$$

For state 1 , the storage voltage, $V_{\mathrm{st}}$ is equal to the voltage across the piezoelectric element, $V$, and in state $2, V_{\mathrm{st}}=-V$.

\section{Conclusions and opportunities for energy harvesting using piezoelectric materials}

Of the non-regenerative power supply technologies presented, batteries still appear to be the most economical option for portable electronics considering mass, volume and available surface area constraints. Lithium-ion cells remain one of the best means of powering portable electronics due to their relatively long cycle life, broad temperature range, long shelf life, low self-discharge rate, rapid charge capability, high rate and power discharge capability, high energy efficiency, high operating voltage, lack of memory effect, and high specific energy and energy density compared to other battery electrochemistries. However, realization of commercial lithium-ion thin-film, thick-film and microbattery battery technologies for application to portable electronics hinges on resolving limitations on intercalation of sufficiently high volumes of lithium, the irreversibility of the structural changes that result from the intercalation, and low current and capacity due to reduced amounts of active material available in the cells. Also, integration of lithium-ion fabrication techniques with CMOS techniques remains a challenge, along with development of economical substrates other than platinum.

Microcombustors and microfuel cells, though promising, require significant work for the realization of commercial devices, and thus far are ill equipped to compete with their macroscaled predecessors. Materials commonly used for MEMS fabrication, e.g. single crystals and glass, cannot achieve the appropriate strengths or lifetimes at combustor operating temperatures. Also, although silicon nitride ceramics have been investigated for microcombustors, significant redesign of structures and use of catalysts and/or preheating are required for operation.

PEM direct methanol fuel cells offer great promise compared to some of the other fuel cell options, but advances in microfluidic system design, temperature and water management are still required for adequate implementation for portable electronic systems.

Of the regenerative systems presented, solar cells have made significant progress in terms of efficiency. Their ease of integration, modularity, lack of emissions or noise, lack of moving parts and use of a readily available resource, i.e. sunlight, make them ideal for certain applications.
However, high cost, dependence on the amount and quality of light, and limitations on available surface area for arrays limit their application.

Standalone microthermoelectric devices are currently the least viable option for MEMS applications due to the lack of large temperature gradients $\left(>10^{\circ} \mathrm{C}\right)$ due to small device volumes $\left(<1 \mathrm{~cm}^{3}\right)$ and limited energy conversion efficiencies.

Opportunities for application of vibration-based power supply systems to wireless sensor systems for ambient intelligence, condition monitoring, medical implants and smart clothing is an area of wide potential. Of the three technologies presented, electromagnetic and piezoelectric appear to be the most promising. Electrostatic devices are currently limited by their high impedance and output voltages, which reduce the amount of available current. Development of microelectromagnetic devices requires enhancement of planar magnet quality and development of assembly and alignment techniques for wafer-scale (sub-millimeter) systems. Currently, piezoelectric energy harvesting devices are the simplest means of scavenging power directly from structural vibrations for several reasons. They require few additional components and relatively simple geometries for the realization of workable devices. Also there are a number of available thin- and thick-film fabrication techniques for application to MEMS devices.

A great deal of research has focused on improving the efficiency, via physical and geometrical configuration, and adaptive circuitry, for piezoelectric energy harvesting devices. So opportunities for enhanced performance depend on development of generator materials. Most fabricated devices have comprised of PVDF and PZT, but there has been little investigation of ferroelectric relaxor-type (e.g. PMN, PZN, PMN-PT and PZN-PT) materials as energy harvesting devices, despite their high electromechanical coupling factors and piezoelectric constants [273]. Hence, the investigation of PMN, PZN, PMN-PT and PZN-PT/polymer composite fabrication and analytical techniques for prediction of performance variables for both $0-3$ and 1-3 connectivity composites is an area worthy of exploration.

Adequate modeling of electromechanical and material performance of these materials will require enhancement of the traditional linear models used to describe piezoelectric energy harvesting devices. Most of these models have been for materials such as PZT, whose performance is not significantly influenced by temperature. Yet, the electromechanical properties of PMN, PZN, PMN-PT and PZN-PT materials are functions of temperature, so future work should include investigation of performance parameters as a function of temperature.

Since the majority of MEMS-scaled piezoelectric energy harvesting devices do not provide enough current to directly power systems of MEMS devices, two areas of investigation are crucial: development of hybrid systems comprising piezoelectric energy harvesting and storage devices, and enhancement of charge density via material and structure advancements. Specifically, development of strategies for designing hybrid systems will be necessary for the design of complete commercial devices. Also, investigation of methods to improve charge density in order to reduce complex signal 
processing and circuitry is needed. Since workers have demonstrated that stacked devices produce enhanced charge and energy densities, mathematical models describing stacked structure performance will also lead to the realization of commercial devices capable of powering MEMS devices.

Regenerative hybrid piezoelectric energy harvesting systems are envisioned for applications requiring lengthy cycle life, such as implantable devices, where 20 year lifetimes are desirable. The ability of piezoelectric devices to capitalize off of inherent device movements and acoustic wave production offer opportunities to continuously charge secondary sources of power such as batteries, which could potentially increase the host device operational lifetime until the active materials of the battery are exhausted or the piezoelectric material cracks or breaks. Thus, development of materials capable of withstanding long lifetimes of cyclic loading is imperative. Lifetime studies have been performed for PZT materials [251], but not for energy harvesting devices comprising PMN, PZN, PMN-PT and PZN-PT and other related composite structures. Furthermore, there has been little investigation of cyclic loading type and duration on electrical and mechanical properties for energy harvesting application. Thus investigation of the response of these materials to continuous loading is crucial for the development of mathematical models that predict device reliability and failure modes.

Reduction of device size, coupled with an increase in the number of devices, could allow for higher frequency oscillation of piezoelectric devices, which would ultimately increase output power [275]. Indeed, as pointed out in several independent areas covered by the present review, nanotechnologies have already revolutionized energy and power density [281-283], efficiency [175, 284, 285] and capacity [175, 284-287] of many storage and generation devices, and thus further investigation of fabrication techniques for nanoscaled piezoelectric energy harvesting devices will certainly allow for the realization of hybrid nanopowered and/or self-power systems for implantable biological and nanosensor systems.

The most fruitful efforts will likely come from hybridized power supplies, which offer both on-board storage and energy harvesting from environmental sources. Though some initial work has been done in optimization of batteries [97, 98] and capacitors [288-290], the literature on optimization of combinations of storage and generation schemes remains sparse. The potential insertion of novel ceramics (composite structures comprised of PMN-PT, PZNPT and nanoarrays) will undoubtedly create opportunities for piezoelectric materials to be used in hybrid schemes, especially given the inexorable trend to smaller microelectronics.

\section{References}

[1] International Technology Roadmap for Semiconductors 2006 Update: Overview and Working Group Summaries 2006 vol 2007 European Semiconductor Industry Association, Japan Electronics and Information Technology Industries Association, Korea Semiconductor Industry Association, Taiwan Semiconductor Industry Association,

Semiconductor Association
[2] Do J S, Yu S H and Cheng S F 2004 Preparation and characterization of thick-film Ni/MH battery Biosens. Bioelectron. 20 61-7

[3] Wang C L, Taherabadi L, Jia G Y, Madou M, Yeh Y T and Dunn B 2004 C-MEMS for the manufacture of 3D microbatteries Electrochem. Solid State Lett. 7 A435-8

[4] Sukumar V et al 2005 High voltage MOSFET gate/bulk driver controller for a microbattery switch matrix in a $0.35 \mu \mathrm{m}$ microwave SOI technology Analog Integr. Circuits Signal Process. 44 203-11

[5] Nathan M, Golodnitsky D, Yufit V, Strauss E, Ripenbein T, Shechtman I, Menkin S and Peled E 2005

Three-dimensional thin-film Li-ion microbatteries for autonomous MEMS J. Microelectromech. Syst. 14 879-85

[6] Wu X M, Xiao Z B, He Z Q, Ma M Y, Liu J B and Xu M F 2006 Preparation and characterization of $\mathrm{Li}_{4 / 3} \mathrm{Ti}_{5 / 3} \mathrm{O}_{4}$ thin films by solution deposition Mater. Lett. $60422-4$

[7] Clark N H and Doughty D H 2005 Development and testing of $100 \mathrm{~kW} / 1 \mathrm{~min} \mathrm{Li}$-ion battery systems for energy storage applications J. Power Sources 146 798-803

[8] Golodnitsky D, Yufit V, Nathan M, Shechtman I, Ripenbein T, Strauss E, Menkin S and Peled E 2006 Advanced materials for the 3D microbattery J. Power Sources 153 281-7

[9] Harb J N, LaFollette R M, Selfridge R H and Howell L L 2002 Microbatteries for self-sustained hybrid micropower supplies J. Power Sources 104 46-51

[10] Singh P, Kaneria S, Anugonda V S, Chen H M, Wang X Q, Reisner D E and LaFollette R M 2006 Prototype silicon micropower supply for sensors IEEE Sensors J. 6 211-22

[11] Tanaka S, Yamada T, Sugimoto S, Li J F and Esashi M 2003 Silicon nitride ceramic-based two-dimensional microcombustor J. Micromech. Microeng. 13 502-8

[12] Yang W M, Chou S K, Shu C, Xue H, Li Z W, Li D T and Pan J F 2003 Microscale combustion research for application to micro thermophotovoltaic systems Energy Convers. Manage. 44 2625-34

[13] Li Z W, Chou S K, Shu C, Yang W M and Xue H 2004 Predicting the temperature of a premixed flame in a microcombustor J. Appl. Phys. 96 3524-30

[14] Li Z W, Chou S K, Shu C, Xue H and Yang W M 2005 Characteristics of premixed flame in microcombustors with different diameters Appl. Therm. Eng. 25 271-81

[15] Li Z W, Chou S K, Shu C and Yang W M 2005 Effects of step height on wall temperature of a microcombustor J. Micromech. Microeng. 15 207-12

[16] Hua J S, Wu M and Kumar K 2005 Numerical simulation of the combustion of hydrogen-air mixture in micro-scaled chambers part II: CFD analysis for a micro-combustor Chem. Eng. Sci. $603507-15$

[17] Spadaccini C M, Zhang X, Cadou C P, Miki N and Waitz I A 2003 Preliminary development of a hydrocarbon-fueled catalytic micro-combustor Sensors Actuators A $103219-24$

[18] Khanna R 2003 MEMS fabrication perspectives from the MIT microengine project Surf. Coat. Technol. 163 273-80

[19] Whalen S, Thompson M, Bahr D, Richards C and Richards R 2003 Design, fabrication and testing of the P-3 micro heat engine Sensors Actuators A 104 290-8

[20] Peirs J, Reynaerts D and Verplaetsen F 2004 A microturbine for electric power generation Sensors Actuators A 113 86-93

[21] Spadaccini C M, Mehra A, Lee J, Zhang X, Lukachko S and Waitz I A 2003 High power density silicon combustion systems for micro gas turbine engines Trans. ASME J. Eng. Gas Turbines Power 125 709-19

[22] Takei F, Cooray N F, Yoshida K, Yoshida H, Ebisu K, Suzuki S and Sawatari N 2005 Development of prototype micro fuel cells for mobile electronics Fujitsu Sci. Tech. J. 41 191-200 
[23] Tang Y H, Stanley K, Wu J, Ghosh D and Zhang J J 2005 Design consideration of micro thin film solid-oxide fuel cells J. Micromech. Microeng. 15 S185-92

[24] Lu G Q and Wang C Y 2005 Development of micro direct methanol fuel cells for high power applications $J$. Power Sources 144 141-5

[25] Nguyen N T and Chan S H 2006 Micromachined polymer electrolyte membrane and direct methanol fuel cells-a review J. Micromech. Microeng. 16 R1-12

[26] Srikar V T, Turner K T, Ie T Y A and Spearing S M 2004 Structural design considerations for micromachined solid-oxide fuel cells J. Power Sources 125 62-9

[27] Yang W M, Chou S K, Shu C, Li Z W and Xue H 2004 A prototype microthermophotovoltaic power generator Appl. Phys. Lett. 84 3864-6

[28] Yang W M, Chou S K, Shu C, Li Z W and Xue H 2002 Development of microthermophotovoltaic system Appl. Phys. Lett. 81 5255-7

[29] Yang W M, Chou S K, Shu C, Xue H and Li Z W 2004 Design, fabrication, and testing of a prototype microthermophotovoltaic system J. Microelectromech. Syst. 13 851-6

[30] Lee J B, Chen Z Z, Allen M G, Rohatgi A and Arya R 1995 A miniaturized high-voltage solar-cell array as an electrostatic mems power-supply J. Microelectromech. Syst. 4 102-108

[31] Sakakibara T, Izua H, Shibata T, Tarui H, Shibata K, Kiyama S and Kawahara N 2002 Multi-source power supply system using micro-photovoltaic devices combined with microwave antenna Sensors Actuators A 95 208-11

[32] Kribus A 2002 Thermal integral micro-generation systems for solar and conventional use Trans. ASME J. Sol. Energy Eng. 124 189-97

[33] Bermejo S, Ortega P, Jimenez J J and Castaner L 2005 Response of c-Si PV arrays under monochromatic light for MEMS power supply J. Micromech. Microeng. 15 1446-53

[34] Chia L C and Feng B 2007 The development of a micropower (micro-thermophotovoltaic) device J. Power Sources 165 455-80

[35] Pan J F, Huang J, Li D T, Yang W M, Tang W X and Xue H 2007 Effects of major parameters on micro-combustion for thermophotovoltaic energy conversion Appl. Therm. Eng. 27 1089-95

[36] Yang W M, Chou S K, Shu C, Li Z W and Xue H 2002 Combustion in micro-cylindrical combustors with and without a backward facing step Appl. Therm. Eng. 22 1777-87

[37] Yang W M, Chou S K, Shu C, Li Z W and Xue H 2003 Research on micro-thermophotovoltaic power generators Sol. Energy Mater. Sol. Cells 80 95-104

[38] Yang W M, Chou S K, Shu C, Xue H and Li Z W 2005 Research on micro-thermophotovoltaic power generators with different emitting materials J. Micromech. Microeng. 15 S239-42

[39] Yang W M, Siawkiang C, Chang S, Hong X and Li Z W 2005 Effect of wall thickness of micro-combustor on the performance of micro-thermophotovoltaic power generators Sensors Actuators A 119 441-5

[40] Arnold D P, Das S, Cros F, Zana I, Allen M G and Lang J H 2006 Magnetic induction machines integrated into bulk-micromachined silicon J. Microelectromech. Syst. 15 406-14

[41] Holmes A S, Hong G D and Pullen K R 2005 Axial-flux permanent magnet machines for micropower generation J. Microelectromech. Syst. 14 54-62

[42] Yin Y, Messier J and Hopwood J A 1999 Miniaturization of inductively coupled plasma sources IEEE Trans. Plasma Sci. 27 1516-24

[43] Murakami T, Okuno Y and Yamasaki H 2005 Radio-frequency power-assisted performance improvement of a magnetohydrodynamic power generator J. Appl. Phys. 987

[44] Murakami T, Okuno Y and Yamasaki H 2005 Rf-assisted magnetohydrodynamic power generation pure-argon plasma Appl. Phys. Lett. 86171502

[45] Lee E 2003 A micro HTS renewable energy/attitude control system for micro/nano satellites IEEE Trans. Appl. Supercond. 13 2263-6

[46] Mikheev A V, Kayukawa N, Okinaka N, Kamada Y and Yatsu S 2006 High-temperature coal-syngas plasma characteristics for advanced MHD power generation IEEE Trans. Energy Convers. 21 242-9

[47] Roundy S 2005 On the effectiveness of vibration-based energy harvesting J. Intell. Mater. Syst. Struct. 16 809-23

[48] Roundy S, Wright P K and Rabaey J 2003 A study of low level vibrations as a power source for wireless sensor nodes Comput. Commun. 26 1131-44

[49] Bozkurt A, Ladabaum I, Atalar A and Khuri-Yakub B T 1999 Theory and analysis of electrode size optimization for capacitive microfabricated ultrasonic transducers IEEE Trans. Ultrason. Ferroelectr. Freq. Control 46 1364-74

[50] Omer S A and Infield D G 2000 Design and thermal analysis of a two stage solar concentrator for combined heat and thermoelectric power generation Energy Convers. Manage. $41737-56$

[51] Funahashi R, Mikami M, Mihara T, Urata S and Ando N 2006 A portable thermoelectric-power-generating module composed of oxide devices J. Appl. Phys. 99066117

[52] Brown S R, Kauzlarich S M, Gascoin F and Snyder G J 2006 $\mathrm{Yb}_{14} \mathrm{MnSb}_{11}$ : new high efficiency thermoelectric material for power generation Chem. Mater. 18 1873-7

[53] Frick G, Osswald F and Heusch B 1996 Vivitron 1995-transient voltage simulation, high voltage insulator tests, electric field calculation Nucl. Instrum. Methods Phys. Res. A 382 37-50

[54] Heusch B et al 1996 VIVITRON 1995 report Nucl. Instrum. Methods Phys. Res. A 382 32-6

[55] Roundy S and Wright P K 2004 A piezoelectric vibration based generator for wireless electronics Smart Mater. Struct. 13 1131-42

[56] Lu F, Lee H P and Lim S P 2004 Modeling and analysis of micro piezoelectric power generators for micro-electromechanical-systems applications Smart Mater. Struct. 13 57-63

[57] Lefeuvre E, Badel A, Richard C and Guyomar D 2005 Piezoelectric energy harvesting device optimization by synchronous electric charge extraction J. Intell. Mater. Syst. Struct. 16 865-76

[58] Sodano H A, Inman D J and Park G 2005 Comparison of piezoelectric energy harvesting devices for recharging batteries J. Intell. Mater. Syst. Struct. 16 799-807

[59] Christen T and Carlen M W 2000 Theory of Ragone plots J. Power Sources 91 210-6

[60] Pell W G and Conway B E 1996 Quantitative modeling of factors determining Ragone plots for batteries and electrochemical capacitors J. Power Sources 63 255-66

[61] Kiehn H A 2003 Battery Technology Handbook 2nd edn (New York: Dekker)

[62] Reddy D L a T B 2002 Handbook of Batteries 3rd edn (New York: McGraw-Hill)

[63] Albertus P, Christensen J and Newman J 2008 Modeling side reactions and nonisothermal effects in nickel metal-hydride batteries J. Electrochem. Soc. 155 A48-60

[64] Doughty D H 1996 Materials issues in lithium ion rechargeable battery technology J. Power Sources 32 75-81

[65] Karami H, Shamsipur M, Ghasemi S and Mousavi M F 2007 Lead-acid bipolar battery assembled with primary chemically formed positive pasted electrode J. Power Sources 164 896-904 
[66] Karpinski A P, Makovetski B, Russell S J, Serenyi J R and Williams D C 1999 Silver-zinc: status of technology and applications J. Power Sources 80 53-60

[67] Megahed S and Scrosati B 1994 Lithium-ion rechargeable batteries J. Power Sources 51 79-104

[68] Berndt D 2003 Maintenance-Free Batteries: Based on Aqueous Electrolyte Lead-Acid, Nickel/Cadmium, Nickel/Metal Hydride: A Handbook of Battery Technology 3rd edn (Philadelphia, PA: Research Studies Press)

[69] Bode H 1997 Lead-Acid Batteries vol AAF-7959, translated by R J Brodd and K V Kordesch (New York: Wiley)

[70] Crompton T R 1995 Battery Reference Book 2nd edn, vol ABN-0259 (Boston, MA: Butterworth-Heinemann)

[71] Uno Falk S and Salkind A J 1969 Alkaline Storage Batteries vol AAI-1179 (New York: McGraw-Hill)

[72] Mantell C L 1983 Energy Systems 2nd edn, vol AAN-3868 (New York: McGraw-Hill)

[73] Reddy D L a T B 2002 Handbook of Batteries 3rd edn (New York: McGraw-Hill)

[74] Bates J B, Dudney N J, Gruzalski G R, Zuhr R A, Choudhury A, Luck C F and Robertson J D 1992 Electrical-properties of amorphous lithium electrolyte thin-films Solid State Ion. 53-6 647-54

[75] Bates J B, Dudney N J, Lubben D C, Gruzalski G R, Kwak B S, Yu X H and Zuhr R A 1995 Thin-film rechargeable lithium batteries J. Power Sources 54 58-62

[76] Bates J B, Dudney N J, Neudecker B, Ueda A and Evans C D 2000 Thin-film lithium and lithium-ion batteries Solid State Ion. $13533-45$

[77] Birke P, Chu W F and Weppner W 1996 Materials for lithium thin-film batteries for application in silicon technology Solid State Ion. 93 1-15

[78] Branci C, Benjelloun N, Sarradin J and Ribes M 2000 Vitreous tin oxide-based thin film electrodes for Li-ion micro-batteries Solid State Ion. 135 169-74

[79] Dudney N J 2000 Addition of a thin-film inorganic solid electrolyte (lipon) as a protective film in lithium batteries with a liquid electrolyte J. Power Sources 89 176-9

[80] Dudney N J and Neudecker B J 1999 Solid state thin-film lithium battery systems Curr. Opin. Solid State Mater. Sci. 4 479-82

[81] Humble P H, Harb J N and LaFollette R 2001 Microscopic nickel-zinc batteries for use in autonomous microsystems J. Electrochem. Soc. 148 A1357-61

[82] Jones S D and Akridge J R 1995 Development and performance of a rechargeable thin-film solid-state microbattery J. Power Sources 54 63-7

[83] Jones S D and Akridge J R 1996 A microfabricated solid-state secondary Li battery Solid State Ion. 86-8 1291-4

[84] Neudecker B J, Dudney N J and Bates J B 2000 'Lithium-free' thin-film battery with in situ plated $\mathrm{Li}$ anode J. Electrochem. Soc. 147 517-23

[85] Neudecker B J, Zuhr R A and Bates J B 1999 Lithium silicon tin oxynitride (LiySiTON): high-performance anode in thin-film lithium-ion batteries for microelectronics J. Power Sources 82 27-32

[86] Park K S, Park Y J, Kim M K, Son J T, Kim H G and Kim S J 2001 Characteristics of tin nitride thin-film negative electrode for thin-film microbattery J. Power Sources $10367-71$

[87] Shukla A K, Venugopalan S and Hariprakash B 2001 Nickel-based rechargeable batteries J. Power Sources 100 125-48

[88] West W C, Whitacre J F, White V and Ratnakumar B V 2002 Fabrication and testing of all solid-state microscale lithium batteries for microspacecraft applications J. Micromech. Microeng. 12 58-62

[89] Yu X H, Bates J B, Jellison G E and Hart F X 1997 A stable thin-film lithium electrolyte: lithium phosphorus oxynitride J. Electrochem. Soc. 144 524-32

[90] Takeuchi E S and Leising R A 2002 Lithium batteries for biomedical applications MRS Bull. 27 624-7
[91] Yang L, Wang B F and Qiu Y L 2005 Safety characteristics of Li-ion batteries evaluated by in situ measurement techniques Chin. Sci. Bull. 50 2552-6

[92] Otsuji H, Kawahara K, Ikegami T and Ebihara K 2006 $\mathrm{LiMn}_{2} \mathrm{O}_{4}$ thin films prepared by pulsed laser deposition for rechargeable batteries Thin Solid Films 506 120-2

[93] Abe K, Ushigoe Y, Yoshitake H and Yoshio M 2006 Functional electrolytes: novel type additives for cathode materials, providing high cycleability performance J. Power Sources 153 328-35

[94] Kobayashi Y, Seki S, Yamanaka A, Miyashiro H, Mita Y and Iwahori T 2005 Development of high-voltage and high-capacity all-solid-state lithium secondary batteries J. Power Sources 146 719-22

[95] Iriyama Y, Kako T, Yada C, Abe T and Ogumi Z 2005 Reduction of charge transfer resistance at the lithium phosphorus oxynitride/lithium cobalt oxide interface by thermal treatment J. Power Sources 146 745-8

[96] Lee K S, Kim Y L and Lee S M 2005 Silver alloying effect on the electrochemical behavior of $\mathrm{Si}-\mathrm{Zr}$ thin film anodes J. Power Sources 146 464-8

[97] Cook K A, Albano F, Nevius P E and Sastry A M 2006 POWER (power optimization for wireless energy requirements): a MATLAB based algorithm for design of hybrid energy systems J. Power Sources 159 758-80

[98] Cook K A and Sastry A M 2005 An algorithm for selection and design of hybrid power supplies for MEMS with a case study of a micro-gas chromatograph system J. Power Sources 140 181-202

[99] Albano F, Chung M D, Blaauw D, Sylvester D M, Wise K D and Sastry A M 2007 Design of an implantable power supply for an intraocular sensor, using POWER (power optimization for wireless energy requirements) J. Power Sources $170216-24$

[100] US Department of Energy 2000 Advanced Microturbine Systems, Program Plan for Fiscal Years 2000 through 2006 (Washington, DC: US Department of Energy) pp 8-10

[101] Waitz I A, Gauba G and Tzeng Y S 1998 Combustors for micro-gas turbine engines Trans. ASME J. Fluids Eng. 120 109-17

[102] Marbach T L and Agrawal A K 2006 Heat-recirculating combustor using porous inert media for mesoscale applications J. Propuls. Power 22 145-50

[103] Yuasa S, Oshimi K, Nose H and Tennichi Y 2005 Concept and combustion characteristics of ultra-micro combustors with premixed flame Proc. Combust. Inst. 30 2455-62

[104] Larminie J and Dicks A 2000 Fuel Cell Systems Explained (New York: Wiley)

[105] Min K B, Tanaka S and Esashi M 2006 Fabrication of novel MEMS-based polymer electrolyte fuel cell architectures with catalytic electrodes supported on porous $\mathrm{SiO}_{2}$ J. Micromech. Microeng. 16 505-11

[106] Hahn R, Wagner S, Schmitz A and Reichl H 2004 Development of a planar micro fuel cell with thin film and micro patterning technologies J. Power Sources 131 73-8

[107] Cha H Y, Choi H G, Nam J D, Lee Y, Cho S M, Lee E S, Lee J K and Chung C H 2004 Fabrication of all-polymer micro-DMFCs using UV-sensitive photoresist Electrochim. Acta $\mathbf{5 0}$ 795-9

[108] Aravamudhan S, Rahman A R A and Bhansali S 2005 Porous silicon based orientation independent, self-priming micro direct ethanol fuel cell Sensors Actuators A 123/124 497-504

[109] Lee C Y, Wu G W and Hsieh C L 2007 In situ diagnosis of micrometallic proton exchange membrane fuel cells using microsensors J. Power Sources 172 363-7

[110] Lee S J, Lee Y M, Lee C Y, Lai J J, Kuan F H and Chuang C W 2007 The performance of miniature metallic PEM fuel cells J. Power Sources 171 148-54 
[111] Buergler B E, Ochsner M, Vuillemin S and Gauckler L J 2007 From macro- to micro-single chamber solid oxide fuel cells J. Power Sources 171 310-20

[112] Zhang Y, Lu J, Shimano S, Zhou H and Maeda R 2007 Development of MEMS-based direct methanol fuel cell with high power density using nanoimprint technology Electrochem. Commun. 9 1365-8

[113] Moore J M, Lakeman J B and Mepsted G O 2002 Development of a PEM fuel cell powered portable field generator for the dismounted soldier J. Power Sources $10616-20$

[114] Zhang X G et al 2007 A preliminary study of a miniature planar 6-cell PEMFC stack combined with a small hydrogen storage canister J. Power Sources 166 441-4

[115] Lu G Q, Wang C Y, Yen T J and Zhang X 2004 Development and characterization of a silicon-based micro direct methanol fuel cell Electrochim. Acta 49 821-8

[116] Yao S C, Tang X D, Hsieh C C, Alyousef Y, Vladimer M, Fedder G K and Amon C H 2006 Micro-electro-mechanical systems (MEMS)-based micro-scale direct methanol fuel cell development Energy 31 636-49

[117] Motokawa S, Mohamedi M, Momma T, Shoji S and Osaka T 2004 MEMS-based design and fabrication of a new concept micro direct methanol fuel cell (mu-DMFC) Electrochem. Commun. 6 562-5

[118] Yamazaki Y 2004 Application of MEMS technology to micro fuel cells Electrochim. Acta 50 663-6

[119] Stanley K G, Czyzewska E K, Vanderhoek T P K, Fan L L Y, Abel K A, Wu Q M J and Parameswaran M 2005 A hybrid sequential deposition fabrication technique for micro fuel cells J. Micromech. Microeng. 15 1979-87

[120] Miles R W, Hynes K M and Forbes I 2005 Photovoltaic solar cells: an overview of state-of-the-art cell development and environmental issues Prog. Cryst. Growth Charact. Mater. $511-42$

[121] King R R, Law D C, Edmondson K M, Fetzer C M, Kinsey G S, Yoon H, Sherif R A and Karam N H 2007 40\% efficient metamorphic GaInP/GaInAs/Ge multijunction solar cells Appl. Phys. Lett. 903

[122] Bashahu M and Nkundabakura P 2007 Review and tests of methods for the determination of the solar cell junction ideality factors Sol. Energy 81 856-63

[123] Baur C, Bett A W, Dimroth F, Siefer G, Meuw M, Bensch W, Kostler W and Strobl G 2007 Triple-junction III-V based concentrator solar cells: perspectives and challenges , Trans. ASME J. Sol. Energy Eng. 129 258-65

[124] Benanti T L and Venkataraman D 2006 Organic solar cells: an overview focusing on active layer morphology Photosynth. Res. $8773-81$

[125] Bosi M and Pelosi C 2007 The potential of III-V semiconductors as terrestrial photovoltaic devices Prog. Photovolt. 15 51-68

[126] Brendel R 2004 Thin-film crystalline silicon mini-modules using porous Si for layer transfer Sol. Energy 77 969-82

[127] Bundgaard E and Krebs F C 2007 Low band gap polymers for organic photovoltaics Sol. Energy Mater. Sol. Cells 91 954-85

[128] Chopra K L, Paulson P D and Dutta V 2004 Thin-film solar cells: an overview Prog. Photovolt. 12 69-92

[129] Dhere N G, Ghongadi S R, Pandit M B, Jahagirdar A H and Scheiman D 2002 CIGS2 thin-film solar cells on flexible foils for space power Prog. Photovolt. 10 407-16

[130] Erten S, Eren E and Icli S 2007 Dye sensitized solar cell based on 1,8-naphthalene benzimidazole comprising carboxyl group Eur. Phys. J. 38 227-30

[131] Feldrapp K, Horbelt R, Auer R and Brendel R 2003 Thin-film ( 25 center dot $5 \mathrm{mu} \mathrm{m}$ ) solar cells from layer transfer using porous silicon with 32 center dot $7 \mathrm{~mA} \mathrm{~cm}^{-1}$ (2) short-circuit current density Prog. Photovolt. 11 105-12
[132] Ferraioli L, Maddalena P, Parretta A, Wang A and Zhao J 2004 Current-voltage characteristics of high-efficiency silicon solar cells from photoluminescence Appl. Phys. Lett. 85 4222-4

[133] Frank A J, Kopidakis N and van de Lagemaat J 2004 Electrons in nanostructured $\mathrm{TiO}_{2}$ solar cells: transport, recombination and photovoltaic properties Coordinat. Chem. Rev. 248 1165-79

[134] Hermann A M 1998 Polycrystalline thin-film solar cells-a review Sol. Energy Mater. Sol. Cells 55 75-81

[135] Koeppe R, Bossart O, Calzaferri G and Sariciftci N S 2007 Advanced photon-harvesting concepts for low-energy gap organic solar cells Sol. Energy Mater. Sol. Cells 91 986-95

[136] Kroon J M et al 2007 Nanocrystalline dye-sensitized solar cells having maximum performance Prog. Photovolt. 15 1-18

[137] Li H, Stolk R L, van der Werf C H M, Rusche M Y S, Rath J K and Schropp R E I 2006 Thin film micro- and polycrystalline silicon nip cells on stainless steel made by hot-wire chemical vapour deposition Thin Solid Films $501276-9$

[138] Li L G, Lu G H, Yang X N and Zhou E L 2007 Progress in polymer solar cell Chin. Sci. Bull. 52 145-58

[139] Lu Z H and Yao Q 2007 Energy analysis of silicon solar cell modules based on an optical model for arbitrary layers Sol. Energy 81 636-47

[140] Lundberg O, Edoff M and Stolt L 2005 The effect of Ga-grading in CIGS thin film solar cells Thin Solid Films 480 520-5

[141] Southwest Photovoltaic (PV) Systems, Inc. 2007 GEPV-50 Solar Module http://www.southwestpv.com/

[142] Mitsubishi Solar Module-110 W 2007 http://store. altenergystore.com/Solar-Panels/ 100-to-149-Watts-Solar-Panels/ Mitsubishi-Electric-PV-MF110EC4-110W-Solar-Panel/ p765/

[143] Alter Systems—go green for life $2007 \mathrm{http} / / / \mathrm{www}$. altersystems.com/catalog/index.php? gclid=CKjWy-acnpECFQ2nGgodoAECOw

[144] Suraprapapich S, Thainoi S, Kanjanachuchai S and Panyakeow S 2006 Quantum dot integration in heterostructure solar cells Sol. Energy Mater. Sol. Cells 90 2968-74

[145] Zhao L, Chen Q, Li C and Shi G Q 2007 Electrochemical fabrication of p-poly (3-methylthiophene)/n-silicon solar cells Sol. Energy Mater. Sol. Cells 91 1811-5

[146] Schultz O, Glunz S W, Riepe S and Willeke G P 2006 High-efficiency solar cells on phosphorus gettered multicrystalline silicon substrates Prog. Photovolt. 14 711-9

[147] Schultz O, Glunz S W and Willeke G P 2004 Multicrystalline silicon solar cells exceeding 20\% efficiency Prog. Photovolt. 12 553-8

[148] Zhao J H, Wang A H, Green M A and Ferrazza F 1998 19.8\% efficient honeycomb textured multicrystalline and $24.4 \%$ monocrystalline silicon solar cells Appl. Phys. Lett. 73 1991-3

[149] Umeno M, Kato T, Egawa T, Soga T and Jimbo T 1996 High efficiency AlGaAs/Si tandem solar cell over 20\% Sol. Energy Mater. Sol. Cells 41-2 395-403

[150] Yang M J, Soga T, Egawa T, Jimbo T and Umeno M 1994 3-terminal monolithic cascade gaas/Si solar-cells Sol. Energy Mater. Sol. Cells 35 45-51

[151] Yamaguchi M, Takamoto T and Araki K 2006 Super high-efficiency multi-junction and concentrator solar cells Sol. Energy Mater. Sol. Cells 90 3068-77

[152] Strengers J J H, Rubinelli F A, Rath J K and Schropp R E I 2006 A combined experimental and computer simulation study of HWCVD nip micro crystalline silicon solar cells Thin Solid Films $\mathbf{5 0 1} 291-4$ 
[153] Chen M, Lu S S and Liao B 2005 On the figure of merit of thermoelectric generators Trans. ASME J. Energy Resources Technol. 127 37-41

[154] Goetzberger A, Hebling C and Schock H W 2003 Photovoltaic materials, history, status and outlook Mater. Sci. Eng. R $401-46$

[155] Li B, Wang L D, Kang B N, Wang P and Qiu Y 2006 Review of recent progress in solid-state dye-sensitized solar cells Sol. Energy Mater. Sol. Cells 90 549-73

[156] Nogueira A F, Longo C and De Paoli M A 2004 Polymers in dye sensitized solar cells: overview and perspectives Coord. Chem. Rev. 248 1455-68

[157] Gordon J M, Katz E A, Feuermann D and Huleihil M 2004 Toward ultrahigh-flux photovoltaic concentration Appl. Phys. Lett. 84 3642-4

[158] Takatsuka H, Noda M, Yonekura Y, Takeuchi Y and Yamauchi Y 2004 Development of high efficiency large area silicon thin film modules using VHF-PECVD Sol. Energy 77 951-60

[159] Berardan D, Alleno E, Godart C, Puyet M, Lenoir B, Lackner R, Bauer E, Girard L and Ravot D 2005 Improved thermoelectric properties in double-filled $\mathrm{Ce}_{y} / 2 \mathrm{Yb}_{y / 2} \mathrm{Fe}_{4-x}(\mathrm{Co} / \mathrm{Ni})_{(x)} \mathrm{Sb}_{-12}$ skutterudites J. Appl. Phys. 98033710

[160] Beyer H, Nurnus J, Bottner H, Lambrecht A, Roch T and Bauer G 2002 PbTe based superlattice structures with high thermoelectric efficiency Appl. Phys. Lett. 80 1216-8

[161] Bottner H, Nurnus J, Gavrikov A, Kuhner G, Jagle M, Kunzel C, Eberhard D, Plescher G, Schubert A and Schlereth K H 2004 New thermoelectric components using microsystem technologies J. Microelectromech. Syst. 13 414-20

[162] Chen J C, Yan Z J and Wu L Q 1996 The influence of Thomson effect on the maximum power output and maximum efficiency of a thermoelectric generator J. Appl. Phys. 79 8823-8

[163] Kim S W, Kimura Y and Mishima Y 2004 Enhancement of high temperature thermoelectric properties of intermetallic compounds based on a skutterudite $\mathrm{IrSb}_{3}$ and a half-Heusler TiNiSb Sci. Technol. Adv. Mater. 5 485-9

[164] Leonov V, Torfs T, Fiorini P and Van Hoof C 2007 Thermoelectric converters of numan warmth for self-powered wireless sensor nodes IEEE Sensors $J$. 7 650-7

[165] Lim J R, Whitacre J F, Fleurial j P, Huang C K, Ryan M A and Myung N V 2005 Fabrication method for thermoelectric nanodevices Adv. Mater. 17 1488-92

[166] Mayer P M and Ram R J 2006 Optimization of heat sink-limited thermoelectric generators Nanoscale Microscale Thermophys. Eng. 10 143-55

[167] Qu W M, Plotner M and Fischer W J 2001 Microfabrication of thermoelectric generators on flexible foil substrates as a power source for autonomous microsystems J. Micromech. Microeng. 11 146-52

[168] Slaton W V and Zeegers J C H 2006 Thermoelectric power generation in a thermoacoustic refrigerator Appl. Acoust. 67 450-60

[169] Strasser M, Aigner R, Lauterbach C, Sturm T F, Franosch M and Wachutka G 2004 Micromachined CMOS thermoelectric generators as on-chip power supply Sensors Actuators A 114 362-70

[170] Venkatasubramanian R, Siivola E, Colpitts T and O'Quinn B 2001 Thin-film thermoelectric devices with high room-temperature figures of merit Nature 413 597-602

[171] Wang W, Jia F L, Huang Q H and Zhang J Z 2005 A new type of low power thermoelectric micro-generator fabricated by nanowire array thermoelectric material Microelectron. Eng. 77 223-9
[172] Weber J, Potje-Kamloth K, Haase F, Detemple P, Voklein F and Doll T 2006 Coin-size coiled-up polymer foil thermoelectric power generator for wearable electronics Sensors Actuators A 132 325-30

[173] Xuan X C 2002 Optimum design of a thermoelectric device Semicond. Sci. Technol. 17 114-9

[174] Yoshida K, Tanaka S, Tomonari S, Satoh D and Esashi M 2006 High-energy density miniature thermoelectric generator using catalytic combustion J. Microelectromech. Syst. 15 195-203

[175] Zhang Q J, Tang X F, Zhai P C, Niino M and Endo C 2005 Recent development in nano and graded thermoelectric materials Functionally Graded Materials VIII vol 492-493 (Zurich-Uetikon: Trans Tech Publications) pp 135-40

[176] US Department of Energy 1987 Atomic Power in Space (Washington, DC: US Department of Energy)

[177] Kurosaki K, Kosuga A, Muta H, Uno M and Yamanaka S $2005 \mathrm{Ag}_{9} \mathrm{TITe}_{5}$ : a high-performance thermoelectric bulk material with extremely low thermal conductivity Appl. Phys. Lett. 873

[178] Beeby S P, Torah R N, Tudor M J, Glynne-Jones P, O’Donnell T, Saha C R and Roy S 2007 A micro electromagnetic generator for vibration energy harvesting J. Micromech. Microeng. 17 1257-65

[179] Umeda M, Nakamura K and Ueha S 1996 Analysis of the transformation of mechanical impact energy to electric energy using piezoelectric vibrator Japan. J. Appl. Phys. 35 3267-73

[180] Umeda M, Nakamura K and Ueha S 1997 Energy storage characteristics of a piezo-generator using impact induced vibration Japan. J. Appl. Phys. 136 3146-51

[181] Ramsay M J and Clark W W 2001 Piezoelectric energy harvesting for bio MEMS applications Smart Struct. Mater. Ind. 4322 429-38

[182] White N M, Glynne-Jones P and Beeby S P 2001 A novel thick-film piezoelectric micro-generator Smart Mater. Struct. 10 850-2

[183] Roundy S 2003 Energy scavenging for wireless sensor nodes with a focus on vibration to electricity conversion $P h D$ University of California, Berkeley

[184] Sodano H A, Inman D J and Park G 2005 Generation and storage of electricity from power harvesting devices J. Intell. Mater. Syst. Struct. 16 67-75

[185] Sodano H A, Lloyd J and Inman D J 2006 An experimental comparison between several active composite actuators for power generation Smart Mater. Struct. 15 1211-6

[186] Engel T G, Keawboonchuay C and Nunnally W C 2000 Energy conversion and high power pulse production using miniature piezoelectric compressors IEEE Trans. Plasma Sci. 28 1338-41

[187] Keawboonchuay C and Engel T G 2003 Maximum power generation in a piezoelectric pulse generator IEEE Trans. Plasma Sci. 31 123-8

[188] Keawboonchuay C and Engel T G 2004 Scaling relationships and maximum peak power generation in a piezoelectric pulse generator IEEE Trans. Plasma Sci. 32 1879-85

[189] Shearwood C and Yates R B 1997 Development of an electromagnetic micro-generator Electron. Lett. 33 1883-4

[190] Mitcheson P D, Miao P, Stark B H, Yeatman E M, Holmes A S and Green T C 2004 MEMS electrostatic micropower generator for low frequency operation Sensors Actuators A 115 523-9

[191] Mitcheson P D, Reilly E K, Toh T, Wright P K and Yeatman E M 2007 Performance limits of the three MEMS inertial energy generator transduction types J. Micromech. Microeng. 17 S211-6

[192] Miles R W, Zoppi G and Forbes I 2007 Inorganic photovoltaic cells Mater. Today 10 20-7

[193] O’Neill M J, McDanal A J, Piszczor M F, George P J, Edwards D L, Brandhorst H W, Eskenazi M I, Botke M M 
and Jaster P M 2003 The stretched lens array (SLA) —a low-risk, cost-effective concentrator array offering wing-level performance of $180 \mathrm{~W} \mathrm{~kg}^{-1}$ and $300 \mathrm{w} \mathrm{m}^{-1}$ (2) at 300 VDC IEEE Aeros. Electron. Syst. Mag. 18 3-9

[194] Xue J G, Uchida S, Rand B P and Forrest S R 2004 4.2\% efficient organic photovoltaic cells with low series resistances Appl. Phys. Lett. 84 3013-5

[195] Grekhov I V, Korotkov S V, Kozlov A K and Stepanyants A L 1997 A high-power high-voltage pulse generator based on reverse switch-on dynistors for an electrostatic precipitator power supply Instrum. Exp. Tech. 40 702-4

[196] Roundy S, Leland E S, Baker J, Carleton E, Reilly E, Lai E, Otis B, Rabaey J M, Wright P K and Sundararajan V 2005 Improving power output for vibration-based energy scavengers IEEE Pervasive Comput. 4 28-36

[197] Beeby S P, Tudor M J and White N M 2006 Energy harvesting vibration sources for microsystems applications Meas. Sci. Technol. 17 R175-95

[198] Williams C B and Yates R B 1996 Analysis of a micro-electric generator for microsystems Sensors Actuators A 52 8-11

[199] Stephen N G 2006 On energy harvesting from ambient vibration J. Sound Vib. 293 409-25

[200] Williams C B, Shearwood C, Harradine M A, Mellor P H, Birch T S and Yates R B 2001 Development of an electromagnetic micro-generator IEE Proc., Circuits Devices Syst. 148 337-42

[201] Amirtharajah R and Chandrakasan A P 1998 Self-powered signal processing using vibration-based power generation IEEE J. Solid-State Circuits $\mathbf{3 3}$ 687-95

[202] Sasaki K, Osaki Y, Okazaki J, Hosaka H and Itao K 2005 Vibration-based automatic power-generation system Microsyst. Technol.-Micro Nanosyst.-Information Storage Processing Syst. 11 965-9

[203] El-hami M, Glynne-Jones R, White N M, Hill M, Beeby S, James E, Brown A D and Ross J N 2001 Design and fabrication of a new vibration-based electromechanical power generator Sensors Actuators A 92 335-42

[204] Mizuno M and Chetwynd D G 2003 Investigation of a resonance microgenerator J. Micromech. Microeng. 13 209-16

[205] Glynne-Jones P, Tudor M J, Beeby S P and White N M 2004 An electromagnetic, vibration-powered generator for intelligent sensor systems Sensors Actuators A $110344-9$

[206] Ching N N H, Wong H Y, Li W J, Leong P H W and Wen Z Y 2002 A laser-micromachined multi-modal resonating power transducer for wireless sensing systems Sensors Actuators A 97/98 685-90

[207] von Buren T and Troster G 2007 Design and optimization of a linear vibration-driven electromagnetic micro-power generator Sensors Actuators A 135 765-75

[208] Pan C T and Wu T T 2007 Development of a rotary electromagnetic microgenerator J. Micromech. Microeng. 17 120-8

[209] Serre C, Perez-Rodriguez A, Fondevilla N, Morante J R, Montserrat J and Esteve J 2007 Vibrational energy scavenging with Si technology electromagnetic inertial microgenerators Microsyst. Technol. 13 1449-661

[210] Scherrer S, Plumlee D G and Moll A J 2005 Energy scavenging device in LTCC materials WMED '05: IEEE Workshop on Microelectronics and Electron Devices (Boise, Idaho, 2005) pp 77-8

[211] Badel A, Benayad A, Lefeuvre E, Lebrun L, Richard C and Guyomar D 2006 Single crystals and nonlinear process for outstanding vibration-powered electrical generators IEEE Trans. Ultrason. Ferroelectr. Freq. Control 53 673-84

[212] Miyazaki M, Tanaka H, Ono G, Nagano T, Ohkubo N and Kawahara T 2004 Electric-energy generation through variable-capacitive resonator for power-free LSI IEICE Trans. Electron. E87C 549-55
[213] Mitcheson P D, Green T C, Yeatman E M and Holmes A S 2004 Architectures for vibration-driven micropower generators J. Microelectromech. Syst. 13 429-40

[214] Tashiro R, Kabei N, Katayama K, Ishizuka Y, Tsuboi F and Tsuchiya K 2000 Development of an electrostatic generator that harnesses the motion of a living body (use of a resonant phenomenon) JSME Int. J. C 43 916-22

[215] Tashiro R, Kabei N, Katayama K, Tsuboi F and Tsuchiya K 2002 Development of an electrostatic generator for a cardiac pacemaker that harnesses the ventricular wall motion J. Artif. Organs 5 239-45

[216] Meninger S, Mur-Miranda J O, Amirtharajah R, Chandrakasan A P and Lang J H 2001 Vibration-to-electric energy conversion IEEE Trans. Very Large Scale Integr. (VLSI) Syst. 9 64-76

[217] Ma W, Zhu R Q, Rufer L, Zohar Y and Wong M 2007 An integrated floating-electrode electric microgenerator J. Microelectromech. Syst. 16 29-37

[218] Miao P, Mitcheson P D, Holmes A S, Yeatman E M, Green T C and Stark B H 2006 Mems inertial power generators for biomedical applications Microsyst. Technol.-Micro Nanosyst.-Information Storage Processing Syst. 12 1079-83

[219] Miao P, Holmes A S, Yeatman E M, Green T C and Mitcheson P D 2004 Micro-machined variable capacitors for power generation Electrostatics 2003 pp 53-8

[220] Stark B H and Green T C 2005 Comparison of SOI, power device structures in power converters for high-voltage, low-charge electrostatic microgenerators IEEE Trans. Electron Dev. 52 1640-8

[221] Stark B H, Mitcheson P D, Miao P, Green T C, Yeatman E M and Holmes A S 2006 Converter circuit design, semiconductor device selection and analysis of parasitics for micropower electrostatic generators IEEE Trans. Power Electron. 21 27-37

[222] Arnau A 2004 Piezoeletric Transducers and Applications (New York: Springer)

[223] Abothu I R, Ito Y, Poosanaas P, Kalpat S, Komarneni S and Uchino K 1999 Sol-gel processing of piezoelectric thin films Ferroelectrics 232 1071-5

[224] Choi W J, Jeon Y, Jeong J H, Sood R and Kim S G 2006 Energy harvesting MEMS device based on thin film piezoelectric cantilevers J. Electroceram. 17 543-8

[225] Chopra S, Sharma S, Goel T C and Mendiratta R G 2004 Effect of annealing temperature on microstructure of chemically deposited calcium modified lead titanate thin films Appl. Surf. Sci. 230 207-14

[226] Chopra S, Sharma S, Goel T C and Mendiratta R G 2004 Sol-gel preparation and characterization of calcium modified lead titanate (PCT) thin films Ceram. Int. 30 1477-81

[227] Demir I, Olson A L, Skinner J L, Richards C D, Richards R F and Bahr D F 2004 High strain behavior of composite thin film piezoelectric membranes Microelectron. Eng. 75 12-23

[228] Fan H Q, Lee S H, Yoon C B, Park G T, Choi J J and Kim H E 2002 Perovskite structure development and electrical properties of PZN based thin films J. Eur. Ceram. Soc. 22 1699-704

[229] Goel T C, Chopra S, Sharma S and Mendiratta R 2005 Structural, dielectric and pyroelectric properties of lanthanum/calcium modified lead titanate thin films Ferroelectrics 327 71-83

[230] Jeon Y B, Sood R, Jeong J H and Kim S G 2005 MEMS power generator with transverse mode thin film PZT Sensors Actuators A 122 16-22

[231] Kumar P, Thakur O, Prakash C and Goel T C 2005 Ferroelectric properties of bulk and thin films of PMNT system Physica B 357 241-7 
[232] Pontes D S L, Leite E R, Pontes F M, Longo E and Varela J A 2001 Microstructural, dielectric and ferroelectric properties of calcium-modified lead titanate thin films derived by chemical processes J. Eur. Ceram. Soc. 21 1107-14

[233] Pontes F M, Pontes D S L, Leite E R, Longo E, Santos E M S, Mergulhao S and Varela J A 2003 Synthesis, ferroelectric and optical properties of $(\mathrm{Pb}, \mathrm{Ca}) \mathrm{TiO}_{3}$ thin films by soft solution processing J. Sol-Gel Sci. Technol. 27 137-47

[234] Terada K, Suzuki T, Kanno I and Kotera H 2007 Fabrication of single crystal PZT thin films on glass substrates Vacuum 81 571-8

[235] Zhong C W, Peng J G, Zhang S R and Zhang W L 2006 Fabrication of PZT thin films with TiOx buffer layers by RF magnetron sputtering Integr. Ferroelectr. 80 281-8

[236] Beeby S P, Torah R N, Grabham N, Tudor M J and White N M 2004 Thick-film piezoelectric materials for high temperature applications Ferroelectrics 313 63-9

[237] Beeby S P and White N M 2000 Thick-film PZT-silicon micromechanical resonator Electron. Lett. 36 1661-2

[238] Chaipanich A 2007 Effect of PZT particle size on dielectric and piezoelectric properties of PZT-cement composites Curr. Appl. Phys. 7 574-7

[239] Granstrom J, Feenstra J, Sodano H A and Farinholt K 2007 Energy harvesting from a backpack instrumented with piezoelectric shoulder straps Smart Mater. Struct. 16 1810-20

[240] Heyliger P, Pei K C and Saravanos D 1996 Layerwise mechanics and finite element model for laminated piezoelectric shells AIAA J. 34 2353-60

[241] Ho C H, Poon Y M and Shin F G 2006 New explicit formulas for the effective piezoelectric coefficients of binary 0-3 composites J. Electroceram. 16 283-8

[242] Kim S, Clark W W and Wang Q M 2005 Piezoelectric energy harvesting with a clamped circular plate: analysis J. Intell. Mater. Syst. Struct. 16 847-54

[243] Kim S, Clark W W and Wang Q M 2005 Piezoelectric energy harvesting with a clamped circular plate: experimental study J. Intell. Mater. Syst. Struct. 16 855-63

[244] Mo C K, Wright R and Clark W W 2007 The effect of electrode pattern on the behavior of piezoelectric actuators in a circular diaphragm structure J. Intell. Mater. Syst. Struct. 18 467-76

[245] Myers R, Vickers M, Kim H and Priya S 2007 Small scale windmill Appl. Phys. Lett. 903

[246] Platt S R, Farritor S, Garvin K and Haider H 2005 The use of piezoelectric ceramics for electric power generation within orthopedic implants IEEE-ASME Trans. Mechatron. 10 455-61

[247] Priya S 2005 Modeling of electric energy harvesting using piezoelectric windmill Appl. Phys. Lett. 873

[248] Schmidt V H 1992 Piezoelectric energy conversion in windmills IEEE Ultrason. Symp. pp 897-904

[249] Shenck N S and Paradiso J A 2001 Energy scavenging with shoe-mounted piezoelectrics IEEE Micro 21 30-42

[250] IEEE 1987 IEEE standard on piezoelectricity IEEE Ultrason. Ferroelectr. Freq. Control Soc. 17610

[251] Platt S R, Farritor S and Haider H 2005 On low-frequency electric power generation with PZT ceramics IEEE-ASME Trans. Mechatron. 10 240-52

[252] Lee H J and Saravanos D A 1998 The effect of temperature dependent material properties on the response of piezoelectric composite materials J. Intell. Mater. Syst. Struct. $9503-8$

[253] Lee H-J 2001 Finite Element Analysis of Active and Sensory Thermopiezoelectric Composite Materials (Cleveland, OH: NASA)

[254] Kim H W, Batra A, Priya S, Uchino K, Markiey D, Newnham R E and Hofmann H F 2004 Energy harvesting using a piezoelectric 'cymbal' transducer in dynamic environment Japan. J. Appl. Phys. 143 6178-83
[255] Cho J, Richards R, Bahr D and Richards C 2005 Optimization of electromechanical coupling for a thin-film PZT membrane: I. Modeling J. Micromech. Microeng. 15 1797-803

[256] Cho J, Anderson M, Richards R, Bahr D and Richards C 2005 Optimization of electromechanical coupling for a thin-film PZT membrane: II. Experiment J. Micromech. Microeng. 15 1804-9

[257] Richards C D, Anderson M J, Bahr D F and Richards R F 2004 Efficiency of energy conversion for devices containing a piezoelectric component J. Micromech. Microeng. 14 717-21

[258] Ito Y 1999 Piezoelectricity Wiley Encyclopedia of Electrical and Electronics Engineering ed J Webster (New York: Wiley)

[259] Wang Q M and Cross L E 1998 Determination of Young's modulus of the reduced layer of a piezoelectric RAINBOW actuator J. Appl. Phys. 83 5358-63

[260] Wagner M, Roosen A, Oostra H, Hoeppener R, de Moya M, Pearce D H and Hooley T 2005 Miniature accordion-shaped low voltage piezo actuators for high displacements J. Eur. Ceram. Soc. 25 2463-6

[261] Yoon H S, Washington G and Danak A 2005 Modeling, optimization, and design of efficient initially curved piezoceramic unimorphs for energy harvesting applications J. Intell. Mater. Syst. Struct. 16 877-88

[262] Funasaka T, Furuhata M, Hashimoto Y and Nakamura K 1998 Piezoelectric generator using a $\mathrm{LiNbO}_{3}$ plate with an inverted domain Ultrasonics Symp. (Sendai, 1998) pp 959-62

[263] Xu C N, Akiyama M, Nonaka K and Watanabe T 1998 Electrical power generation characteristics of PZT piezoelectric ceramics IEEE Trans. Ultrason. Ferroelectr. Freq. Control 45 1065-70

[264] Islam R A and Priya S 2006 Realization of high-energy density polycrystalline piezoelectric ceramics Appl. Phys. Lett. 883

[265] Singh S, Thakur O P, Prakash C and Raina K K 2005 Dielectric, ferroelectric and piezoelectric properties of La-modified PCT ceramics Physica B 369 64-71

[266] Singh S, Thakur O P, Prakash C and Raina K K 2005 Dilatometric and dielectric behaviour of Sm modified PCT ceramics Physica B 355 280-5

[267] Singh S, Thakur O P, Rawal D S, Prakash C and Raina K K 2005 Improved properties of Sm substituted PCT ceramics using microwave sintering Mater. Lett. 59 768-72

[268] Newham R E, Skimmer D P and Cross L E 1978 Connectivity and piezoelectric-pyroelectric composites Mater. Res. Bull. 13 525-36

[269] Safari A, Janas V F and Bandyopadhyay A 1997 Development of fine-scale piezoelectric composites for transducers AIChE J. 43 2849-56

[270] Mohammadi F, Kholkin A L, Jadidian B and Safari A 1999 High-displacement spiral piezoelectric actuators Appl. Phys. Lett. 75 2488-90

[271] Shen M R, Han J P and Cao W W 2003 Electric-field-induced dielectric anomalies in $\mathrm{C}$-oriented $0.955 \mathrm{~Pb}\left(\mathrm{Zn}_{1 / 3} \mathrm{Nb}_{2 / 3}\right) \mathrm{O}-3-0.045 \mathrm{PbTiO}(3)$ single crystals Appl. Phys. Lett. 83 731-3

[272] Park S E and Shrout T R 1997 Ultrahigh strain and piezoelectric behavior in relaxor based ferroelectric single crystals J. Appl. Phys. 82 1804-11

[273] Zhang S J, Lebrun L, Jeong D Y, Randall C A, Zhang Q M and Shrout T R 2003 Growth and characterization of Fe-doped $\mathrm{Pb}\left(\mathrm{Zn}_{1 / 3} \mathrm{Nb}_{2 / 3}\right) \mathrm{O}-3-\mathrm{PbTiO} 3$ single crystals J. Appl. Phys. 93 9257-62

[274] Gao P X, Song J H, Liu J and Wang Z L 2007 Nanowire piezoelectric nanogenerators on plastic substrates as flexible power sources for nanodevices Adv. Mater. 1967 
[275] Priya S, Chen C T, Fye D and Zahnd J 2005 Piezoelectric windmill: a novel solution to remote sensing Japan. $J$. Appl. Phys. 244 L104-7

[276] Ren K L, Liu Y M, Geng X C, Hofmann H F and Zhang Q M M 2006 Single crystal PMN-PT/epoxy 1-3 composite for energy-harvesting application IEEE Trans. Ultrason. Ferroelectr. Freq. Control 53 631-8

[277] Fang H B, Liu J Q, Xu Z Y, Dong L, Chen D, Cai B C and Liu Y 2006 A MEMS-based piezoelectric power generator for low frequency vibration energy harvesting Chin. Phys. Lett. 23 732-4

[278] Mateu L and Moll F 2005 Optimum piezoelectric bending beam structures for energy harvesting using shoe inserts J. Intell. Mater. Syst. Struct. 16 835-45

[279] Allen J J and Smits A J 2001 Energy harvesting eel J. Fluids Struct. 15 629-40

[280] Taylor G W, Burns J R, Kammann S M, Powers W B and Welsh T R 2001 The energy harvesting eel: a small subsurface ocean/river power generator IEEE J. Ocean. Eng. 26 539-47

[281] Jiang J, Hall T D, Tsagalas L, Hill D A and Miller A E 2006 Photographic production of metal nano-particles for fuel cell electrodes J. Power Sources 162 977-84

[282] Kim S D, Moon H, Hyun S H, Moon J, Kim J and Lee H W 2006 Nano-composite materials for high-performance and durability of solid oxide fuel cells J. Power Sources $163392-7$

[283] Liu Y, Hashimoto S, Nishino H, Takei K and Mori M 2007 Fabrication and characterization of a co-fired
$\mathrm{La}_{0.6} \mathrm{Sr}_{0.4} \mathrm{Co}_{0.2} \mathrm{Fe}_{0.8} \mathrm{O}_{3}$-delta cathode-supported

$\mathrm{Ce}_{0.9} \mathrm{Gd}_{0.1} \mathrm{O}_{1.95}$ thin-film for IT-SOFCs J. Power Sources $16456-64$

[284] Jiang C H, Honma I, Kudo T and Zhou H S 2007

Nanocrystalline rutile $\mathrm{TiO}_{2}$ electrode for high-capacity and high-rate lithium storage Electrochem. Solid State Lett. 10 A127-9

[285] Livshits V, Ulus A and Peled E 2006 High-power H-2/Br-2 fuel cell Electrochem. Commun. 8 1358-62

[286] Hosono E, Fujihara S, Honma I, Ichihara M and Zhou H S 2006 Fabrication of nano/micro hierarchical $\mathrm{Fe}_{2} \mathrm{O}_{3} / \mathrm{Ni}$ micrometer-wire structure and characteristics for high rate Li rechargeable battery J. Electrochem. Soc. 153 A1273-8

[287] Kasavajjula U, Wang C S and Appleby A J 2007 Nano- and bulk-silicon-based insertion anodes for lithium-ion secondary cells J. Power Sources 163 1003-39

[288] Bajolet A, Clerc R, Pananakakis G, Tsamados D, Picollet E, Segura N, Giraudin J C, Delpech P, Montes L and Ghibaudo G 2007 Low-frequency series-resistance analytical modeling of three-dimensional metal-insulator-metal capacitors IEEE Trans. Electron Devices $\mathbf{5 4} 742-51$

[289] Chen J and He L 2007 Efficient in-package decoupling capacitor optimization for I/O power integrity IEEE Trans. Comput. Aided Des. Integr. Circuits Syst. 26 734-8

[290] Vuillermet Y, Chadebec O, Lupin J M, Saker A, Meunier G and Coulomb J L 2007 Optimization of low-voltage metallized film capacitor geometry IEEE Trans. Magn. 43 1569-72 